\title{
Criticism of the NOVA classification: who are the protagonists?
}

Authors: Melissa Mialon ${ }^{\mathrm{a}}$, Paulo Sêrodio ${ }^{\mathrm{b}}$, Fernanda Baeza Scagliusi $^{\mathrm{a}}$

a Departamento de Nutrição, Faculdade de Saúde Pública, Universidade de São Paulo (USP), São Paulo, Brazil

b School of Economics, University of Barcelona, Barcelona, Spain

\section{Funding}

This work was supported by the São Paulo Research Foundation (FAPESP), Brazil under grant number 2017/24744-0 to MM. FBS was supported by the Brazilian National Council for Scientific and Technological Development (CNPq) (grant number 311357/2015-6). The authors are solely responsible for the opinions, hypotheses and conclusions or recommendations expressed in this publication, and they do not necessarily reflect FAPESP and/or CNPq vision.

Editorial note: This paper was subject to blind reviews by three peer reviewers. It was received on December 10, 2018 and accepted for publication on December 28. 


\section{Abstract}

The NOVA classification is based on the extent and purpose of industrial processing of foods and beverages. It is increasingly used by health authorities as an effective proxy for the healthiness of these products. In particular, the consumption of ultra-processed food and beverage products (UPP) is associated with an increased risk of developing noncommunicable diseases. NOVA has also been criticised. In this paper, our hypothesis was that this criticism came from individuals who had relationships with the UPP industry, one way or another. Between August and December 2018, we undertook a series of searches on PubMed, Google and Web of Science, to map the relationships between these individuals and the UPP industry. In total, we identified thirty-two materials criticising the NOVA classification, most of which were non-peer-reviewed. We identified 38 individuals as authors of these documents, among which we found 33 who had relationships with the UPP industry. Among the five individuals for whom we found no relationships with the industry, two were recent graduates and one had no known affiliation. During our analysis, we identified three types of relationships. The first one was when these individuals directly worked with the industry. The second type of relationship was conflicts of interest that individuals declared in their publications, or that they did not declare, but that we found online. The third type of relationship was when the organisations that hosted or presented the criticism of NOVA had relationships with the UPP industry. This study showed that there is currently a need for greater transparency in research and scientific reviews, as many of these relationships were not declared in the materials criticising NOVA. 


\section{Introduction}

Non-Communicable Diseases (NCD) are the leading cause of mortality, globally (World Health Organization 2014). One of the main risk factors for developing NCD is unhealthy diets, particularly those high in ultra-processed food and beverage products (UPP) (World Health Organization 2014; World Health Organization 2004; Pan American Health Organization 2015).

UPP are one of the groups in the NOVA classification (Group 4), which is based on the extent and purpose of industrial processing of foods and beverages, and was first introduced in 2009 by a Brazilian research group (Monteiro 2009). Group 1 in NOVA is made of unprocessed or minimally processed foods; Group 2 includes "processed culinary ingredients, such as oils, butter, sugar and salt, are substances derived from Group 1 foods or from nature by processes that include pressing, refining, grinding, milling and drying” (Monteiro et al. 2018); Group 3 is made of processed foods, made essentially by adding ingredients from Group 2 to Group 1 foods (Monteiro et al. 2018). UPP, in Group 4, are "formulations made mostly or entirely from substances derived from foods and additives" and their consumption has been linked to "unhealthy dietary nutrient profiles and several diet-related non-communicable diseases” (Monteiro et al. 2018).

This type of classification is increasingly recognised as an effective proxy for the healthiness of these products (Moubarac et al. 2014; Monteiro et al. 2018a; Fiolet et al. 2018). NOVA was included the Dietary Guidelines for the Brazilian Population in 2014 (Ministry of Health 2014) and was later endorsed by the Pan-American Health Organization (Pan American Health Organization 2015). From 2013-2016, numerous articles about NOVA were published in World Nutrition (Monteiro 2011; Monteiro et al. 2012; Monteiro et al. 2016). In 2018, NOVA was the subject of a series of publications in the journal Public Health Nutrition (Public Health Nutrition 2018). This classification is now used in the Uruguayan dietary guidelines (Food and Agriculture Organization of the United Nations 2016) and was cited in a Senate report in Canada (Standing Senate Committee on Social Affairs 2016) and by the French High Council of Public Health in its recommendations for the new French dietary guidelines (Haut Conseil de la Santé Publique 2018).

NOVA has also been criticised by scientists (Gibney et al. 2017). Criticism is essential in science, as it helps stimulate and refine scientific progress. However, our hypothesis is that criticism of the NOVA classification has come mainly from individuals and/or organisations that have had relationships with the UPP industry, one way or another. We define the UPP industry as companies that make most of their profits from UPP. This includes manufacturers, ingredient suppliers, trade associations, etc. The UPP industry has a conflict of interest (COI) in discussions on the impacts of UPP on health. The existence of the UPP industry relies on the sales of these products. Any evidence that demonstrates an association between UPP consumption and an increased risk of NCD, or supports the regulation of the sale of these products, represents a threat to these profits.

In an attempt to mitigate any potential threats to the industry, companies engage in information management, which consists of shaping the evidence base in ways favourable to corporations (Mialon, Swinburn, and Sacks 2015; Mialon, Julia, and Hercberg 2018; Oreskes and Conway 2011; Michaels 2008). This is a well-documented political strategy of the UPP industry and is part of a broader set of strategies that aim to influence public polices and public opinion, also known as "corporate political activity” (CPA) (Mialon, Swinburn, and Sacks 2015; Mialon, Julia, and Hercberg 2018). For this study, our 
hypothesis was that the UPP industry might be using such an information management strategy in the case of the NOVA classification. For example, in 2017, Monteiro et al. published a response to a commentary that criticised the classification (Monteiro et al. 2018b; Gibney et al. 2017). They noted that the article contained "factual and conceptual errors" (and proposed a rebuttal to each of these errors) and provided inappropriate references to the literature (citing for example an article on famine while discussing about the association between the consumption of UPP and obesity) (Monteiro et al. 2018b). They also pointed to the lack of transparency about the conflicts of interests between the authors of that article and the UPP industry (Monteiro et al. 2018b).

In this study, our aim was to identify the relationships, if any, between individuals and organisations who have recently criticised the NOVA classification and the UPP industry. We therefore explored the COI that these individuals/organisations had with the UPP industry and how these were reported, as it represents a bias for those who have criticised these types of food and beverage classifications. This article therefore discusses about COI and transparency in research in the context of the NOVA classification. Our intention was not to assess the content of the criticism, which would have been beyond the scope of this article, but to describe these relationships and COI.

\section{Methods}

All searches were conducted between August and December 2018.

First, we undertook a search on PubMed, on 1 August 2018, using the keyword "ultraprocessed', with no limit to our timeframe or language. Our inclusion criterion was that the publications should criticise the NOVA classification of foods and beverages. From 168 results obtained from this search, only one commentary matched this criterion (Gibney et al. 2017). We then conducted backward searches, where we collected relevant publications, in accordance with our inclusion criterion, from the references section of the identified commentary (Gibney et al. 2017) and then from any new publication that we found. We also conducted forward searches on Scopus to identify other publications that cited the commentary and any other scientific publications identified during data collection. Finally, we contacted NOVA experts to identify additional material. We expanded these searches for all materials that we later identified during this study, through contact with experts.

We then identified information relevant to the relationships between the authors of the materials collected for this study and the UPP industry. We used information provided in the materials themselves, and conducted additional searches online, using Google, with the name of the authors as search terms. We did not limit our analysis to a certain timeframe. We searched for:

1. Declarations of interest sections in scientific publications;

2. The funding acknowledgments sections, in the same publications;

3. The institutions to which the authors were affiliated, as declared in these publications, and any links between these institutions and the UPP industry;

4. Any relationship between the institutions where the materials retrieved were hosted/presented and the UPP industry;

5. Other relationships between the authors and the UPP industry, such as participation in meetings or awards received from the industry.

In addition, we used Web of Science Core Collection to retrieve the publication profile of the individuals identified in the searches described above (Appendix 1 presents our 
search parameters). We only conducted these searches for individuals who were affiliated to academic institutions and therefore did not directly work with the UPP industry. This condition removed seven individuals from our search, such as consultants working with the industry, therefore having an ex ante COI. We searched for the individuals' name and university affiliation and retrieved the metadata associated with their publications. In particular, we parsed through the $\mathrm{COI} /$ funding statements and identified which of the entities mentioned in the statement were associated with the UPP industry.

Using this information, we created two types of networks. First, we connected individuals to the companies operating in the UPP industry, based on reported ties between them. These networks are called two-mode networks, as they connect two different entities: individuals and organisations. We plotted two of these networks: the first using information obtained from the aforementioned Google searches; the second used information we obtained from the funding statements in the publications retrieved from our Web of Science search. The second type of network depicts co-authorship patterns, as it uses the metadata on the publications yielded by our Web of Science search, and creates ties between each pair of authors in each co-authored publication. We display a simple co-authorship network where we highlight the authors of materials criticising NOVA classification. Furthermore, to better understand the structure of the co-authorship network, we ran the Girvan-Newman algorithm to detect research communities in the network. This is a graph-theoretic iterative procedure that calculates edge-betweenness centrality for each edge in the network (that is, it calculates the degree to which that edge acts like a bridge between all other dyads in the network), removes it, recalculates edge betweenness, continually disconnecting the graph until visible clusters start to appear. The procedure maximises modularity, a measure that determines how "good" are the clusters/communities identified by the algorithm, based on comparing the number of ties within clusters vis-a-vis what we would expect by chance. The optimal partition of the network is that which maximises the modularity score.

This study was designed as a preliminary inquiry. Therefore, the list of relationships between individuals/organisations and the UPP industry presented in this manuscript was not meant to be exhaustive, but rather illustrative.

Finally, we want to reflect on the fact that two of us are currently employed by NUPENS (one of us joined the group in 2018), the group that initially developed NOVA, although we were not involved in that work, but other projects in qualitative research. This represents a bias which may influence our exploration of the criticism of NOVA.

\section{Results}

In total, we identified 32 materials criticising the NOVA classification (or more broadly, the classification of foods and beverages, based on their extent and purpose of processing). Among these 32 materials, seven were scientific articles. Other materials included commentaries, editorials and other non-peer-reviewed materials in scientific journals, as well as videos and a website, oral presentations at scientific and industry events, as well as a public hearing for a new bill. These documents were published/presented in Belgium, Brazil, Colombia, France, the United Kingdom (UK) and the United States of America (USA).

We identified 38 individuals as authors of these documents. The list of materials retrieved and individuals who authored these documents is presented in Table 1. The key messages from the materials questioning NOVA are presented in Appendix 2. 
Table 1: Authors and materials where the classifications of food and beverages based on their extent and purpose of processing was criticised

\begin{tabular}{|c|c|}
\hline Nature and details about the document & $\begin{array}{l}\text { Authors (alphabetical order } \\
\text { for each document), }\end{array}$ \\
\hline $\begin{array}{l}\text { 1. Scientific article: Contributions of Processed Foods to } \\
\text { Dietary Intake in the US from 2003-2008: A Report of the } \\
\text { Food and Nutrition Science Solutions Joint Task Force of } \\
\text { the Academy of Nutrition and Dietetics, American Society } \\
\text { for Nutrition, Institute of Food Technologists, and } \\
\text { International Food Information Council. Journal of } \\
\text { Nutrition. 2012; 142(11):2065S-72S }\end{array}$ & $\begin{array}{l}\text { Eicher-Miller, Heather*; } \\
\text { Fulgoni III, Victor*; } \\
\text { Keast, Debra*. }\end{array}$ \\
\hline $\begin{array}{l}\text { 2. Scientific article: Processed Food Contributions to Energy } \\
\text { and Nutrient Intake Differ among US Children by } \\
\text { Race/Ethnicity. Nutrients. 2015; 7(12): 10076-88 }\end{array}$ & $\begin{array}{l}\text { Eicher-Miller, Heather*; } \\
\text { Fulgoni III, Victor*; } \\
\text { Keast, Debra*. }\end{array}$ \\
\hline $\begin{array}{l}\text { 3. Scientific article: Energy and Nutrient Intakes from } \\
\text { Processed Foods Differ by Sex, Income Status, and } \\
\text { Race/Ethnicity of US Adults. Journal of the Academy of } \\
\text { Nutrition and Dietetics. 2015; 15(6): 907-18.e6 }\end{array}$ & $\begin{array}{l}\text { Eicher-Miller, Heather*; } \\
\text { Fulgoni III, Victor*; } \\
\text { Keast, Debra*. }\end{array}$ \\
\hline $\begin{array}{l}\text { 4. Scientific article: Comparison of Child Lunch Meals in } \\
\text { Brazil. Food and Nutrition Sciences. 2016; 7: 262-72 }\end{array}$ & $\begin{array}{l}\text { Franciscato Cozzolino, } \\
\text { Silvia Maria; } \\
\text { Martins, Carolina; } \\
\text { Sanchez Oliveira Jensen, } \\
\text { Natália. }\end{array}$ \\
\hline $\begin{array}{l}\text { 5. Scientific article: The Myth of Ultra-Processed Foods. EC } \\
\text { Nutrition. 2017; 12(3): 148-51 }\end{array}$ & $\begin{array}{l}\text { Madi, Luis*; } \\
\text { Vialta, Airton*; } \\
\text { Rego, Raul Amaral*. }\end{array}$ \\
\hline $\begin{array}{l}\text { 6. Scientific article: Les aliments hyper-transformés : un } \\
\text { nouveau concept discuté. Médecine des Maladies } \\
\text { Métaboliques. 2018; 12(4): 381-6 }\end{array}$ & Lecerf, Jean Michel. \\
\hline $\begin{array}{l}\text { 7. Scientific article: Ultra-processed foods: definitions and } \\
\text { policy issues. Current Developments in Nutrition. 2018; } \\
\text { nzy077, https://doi.org/10.1093/cdn/nzy077 }\end{array}$ & Gibney, Michael*. \\
\hline $\begin{array}{l}\text { 8. Letter in a scientific journal: Nutrient profiling: The good, } \\
\text { the bad, and the ultra-processed. Public Health Nutrition. } \\
\text { 2009;12(10): } 1967-70\end{array}$ & Darmon, Nicole. \\
\hline $\begin{array}{l}\text { 9. Scientific statement in a scientific journal: Processed } \\
\text { foods: contributions to nutrition. American Journal of } \\
\text { Clinical Nutrition. 2014;99: 1525-42 }\end{array}$ & $\begin{array}{l}\text { Dwyer, Johanna*; } \\
\text { Fulgoni III, Victor*; } \\
\text { King, Janet; } \\
\text { Leveille, Gilbert; } \\
\text { MacDonald, Ruth; } \\
\text { Ordovas, Jose; } \\
\text { Schnakenberg, David; } \\
\text { Weaver, Connie. }\end{array}$ \\
\hline $\begin{array}{l}\text { 10. Communication in a scientific journal: Brasil Processed } \\
\text { Food 2020: um projeto em defesa da industrialização de } \\
\text { alimentos. Brazilian Journal of Food Technology. 2015; } \\
\text { 18(4): 337-9 }\end{array}$ & $\begin{array}{l}\text { Madi, Luis*; } \\
\text { Rego, Raul Amaral*. }\end{array}$ \\
\hline $\begin{array}{l}\text { 11. Commentary in a scientific journal: Ultra-processed foods } \\
\text { in human health: a critical appraisal. American Journal of } \\
\text { Clinical Nutrition. 2017; 106:717-24 (and corrigendum) }\end{array}$ & $\begin{array}{l}\text { Forde, Ciaran; } \\
\text { Gibney, Eileen; } \\
\text { Gibney, Michael*; }^{*} \text { Mullally, Deirdre. }\end{array}$ \\
\hline $\begin{array}{l}\text { 12. Review of a scientific article: aliments « ultra- } \\
\text { transformés» et cancer. Cahiers de Nutrition et Diététique. } \\
\text { 2018; 53: 74-5 }\end{array}$ & Guy-Grand, Bernard. \\
\hline
\end{tabular}




\begin{tabular}{|c|c|c|}
\hline & $\begin{array}{l}\text { Editorial in a scientific journal: Alimentation, santé } \\
\text { publique, étiquetage, où va-t-on ? Cahiers de Nutrition et } \\
\text { Diététique. 2018; 53: 123-4 }\end{array}$ & Chardigny, Jean-Michel. \\
\hline & $\begin{array}{l}\text { Publication resulting from an event: Is "Processed” a } \\
\text { Four-Letter Word? The Role of Processed Foods in } \\
\text { Achieving Dietary Guidelines and Nutrient } \\
\text { Recommendations. American Society for Nutrition. } \\
\text { Advances in Nutrition. 2012; 3: 536-48 }\end{array}$ & $\begin{array}{l}\text { Clemens, Roger*; } \\
\text { Dwyer, Johanna*; } \\
\text { Freedman, Marjorie ; } \\
\text { Fulgoni III, Victor*; } \\
\text { Schmidt, David. }\end{array}$ \\
\hline 15. & $\begin{array}{l}\text { Publication resulting from an event: Conference on } \\
\text { 'Nutrient-nutrient interaction' - Plenary Lecture 1- Food } \\
\text { processing: criteria for dietary guidance and public health? } \\
\text { Nutrition Society Scottish Section Meeting held at the } \\
\text { Royal College of Physicians and Surgeons, Glasgow on } \\
\text { 26-27 March 2018. Proceedings of the Nutrition Society. } \\
\text { 2018; doi:10.1017/S0029665118002513 }\end{array}$ & Miller Jones, Julie*. \\
\hline & $\begin{array}{l}\text { Event: AACCI Events \& News: Cereals } 17 \text { Symposium: } \\
\text { Food selection according to food processing: fabulous or } \\
\text { flawed? Processed and Ultraprocessed Foods Defined - An } \\
\text { Alice in Wonderland Question? } 2017\end{array}$ & $\begin{array}{l}\text { Clemens, Roger*; } \\
\text { Miller Jones, Julie*. }\end{array}$ \\
\hline & $\begin{array}{l}\text { Event: AACCI Events \& News: Cereals } 17 \text { Symposium: } \\
\text { Food selection according to food processing: fabulous or } \\
\text { flawed? Introductory Brain Teaser for the Cereal Chemist } \\
\text { - How Do We Categorize Processed and Ultraprocessed } \\
\text { Foods? } 2017\end{array}$ & $\begin{array}{l}\text { Clemens, Roger*; } \\
\text { Miller Jones, Julie*. }\end{array}$ \\
\hline 18. & $\begin{array}{l}\text { Event: The Nutrition Society, Spring Conference 2018: } \\
\text { Nutrient-nutrient interaction, Plenary Lecture One Avoid } \\
\text { processed and ultra-processed foods: Sound bite advice or } \\
\text { just a sound bite. } 2018\end{array}$ & Miller Jones, Julie*. \\
\hline 19. & $\begin{array}{l}\text { Event: Belgian Nutrition Society, Eight annual meeting, } \\
\text { May 4th, 2018: Session 1: Keynote 1: Ultra-processed } \\
\text { foods in human health: a critical appraisal. } 2018\end{array}$ & Gibney, Michael*. \\
\hline 20. & $\begin{array}{l}\text { Event: Séance hebdomadaire de l'Académie d'Agriculture } \\
\text { de France: Des matières premières agricoles aux aliments : } \\
\text { Quel impact des procédés de transformation sur la qualité } \\
\text { de l'alimentation? (6 documents in total). } 2018 \\
\text { a. Introduction - Gérard Pascal } \\
\text { b. Impacts des opérations et procédés sur les } \\
\text { attributs des aliments - Gilles Trystram } \\
\text { c. Mieux connaître la transformation industrielle } \\
\text { et la diversité de nos aliments pour une } \\
\text { alimentation plus saine et plus durable : } \\
\text { exemple d’une cartographie multicritère du } \\
\text { marché français des pizzas- Isabelle Souchon } \\
\text { d. La structure des aliments module leur cinétique } \\
\text { de digestion et la biodisponibilité des } \\
\text { nutriments - Didier Dupont } \\
\text { e. Conclusion - Véronique Braesco }\end{array}$ & $\begin{array}{l}\text { Pascal, Gérard; } \\
\text { Trystram, Gilles; } \\
\text { Souchon, Isabelle; } \\
\text { Dupont, Didier; } \\
\text { Braesco, Véronique. }\end{array}$ \\
\hline & $\begin{array}{l}\text { Project: } \text { Brasil Processed Food } 2020 \\
\text { a. } \\
\text { Publication: ITAL. Alimentos industrializados: } \\
\text { a importância para a sociedade brasileira . } \\
\text { Editores: Rego R. A., Vialta A. and Madi L. } \\
\text { 2018. } \\
\text { http://alimentosindustrializados.com.br/2/ }\end{array}$ & $\begin{array}{l}\text { Madi, Luis*; } \\
\text { Vialta, Airton*; } \\
\text { Rego, Raul Amaral*. }\end{array}$ \\
\hline
\end{tabular}




\begin{tabular}{|c|c|}
\hline $\begin{array}{l}\text { b. website: } \\
\text { http://www.alimentosprocessados.com.br/plataf } \\
\text { orma.php }\end{array}$ & \\
\hline $\begin{array}{l}\text { 22. Public hearing: Comentarios al Proyecto de Ley } 07 \text { de } \\
2017 \text { por Jairo Romero, audiencia publica de la comisión } \\
\text { séptima del senado de la republica de Colombia, Octubre } \\
26 \text { de 2017. } 2017\end{array}$ & Romero, Jairo. \\
\hline $\begin{array}{l}\text { 23. Other presentation: Acerca de los sistemas de clasificación } \\
\text { de alimentos y su racionalidad científica, } \mathrm{II}^{\mathrm{O}} \text { consejo } \\
\text { tecnico de IFAN, Santiago de Chile, } 27 \text { de marzo, } 2018 \text {. } \\
2018\end{array}$ & Morán, Javier. \\
\hline $\begin{array}{l}\text { 24. Video: One Size Doesn't Fit All When it Comes To } \\
\text { Processed Foods } \\
\text { http://bcove.me/gzuw84ji }\end{array}$ & Eicher-Miller, Heather*. \\
\hline $\begin{array}{l}\text { 25. Video: Processed Food Makes Our Lives Better } \\
\text { http://bcove.me/0nq5lbx2 }\end{array}$ & Decker, Eric. \\
\hline $\begin{array}{l}\text { 26. Video: Everything is Processed } \\
\text { http://bcove.me/p3fyebvk }\end{array}$ & Floros, John. \\
\hline $\begin{array}{l}\text { 27. Video: Processed Foods Wonderful For Women } \\
\text { http://bcove.me/77r4zm4t }\end{array}$ & Shelke, Kantha. \\
\hline
\end{tabular}

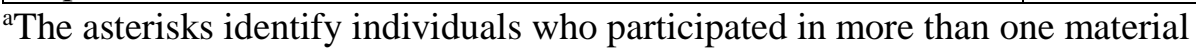

${ }^{b}$ For authors in italics, we found no evidence of a relationship with the UPP industry

From the preliminary searches using the materials retrieved for this study and Google, we found that at least 31 individuals interacted, at some point, with the UPP industry. Ten individuals (one quarter of all authors) appeared on more than one publication. All evidence for data included in Table 1 and in the results section of this manuscript is available as Appendix 3.

During our analysis, we identified three types of relationships. The first one was when individual authors directly worked with the UPP industry. The second type of relationship was the COI that individual authors declared in their publications, or that they did not declare, but that we found online. The third type of relationship was between organisations that hosted or presented criticism of NOVA and the UPP industry. In this manuscript, we will present each of these relationships.

\section{Individuals who worked with the UPP industry}

We first identified that, at the time of publication of the materials included in this study, seven individuals (a fifth of all authors) worked with the UPP industry, as detailed in their affiliations or declarations of interests, as shown in Table 2. This represents a COI in the discussion of concern, as described earlier.

Table 2: Individuals who were working, or recently worked, with the UPP industry at the time of publication (in alphabetical order)

\begin{tabular}{|l|l|l|l|}
\hline $\begin{array}{l}\text { Name of } \\
\text { individual } \\
\text { (alphabetical } \\
\text { order) }\end{array}$ & Country & Industry affiliation & $\begin{array}{l}\text { Principal activity of the industry } \\
\text { actor }\end{array}$ \\
\hline $\begin{array}{l}\text { Braesco, } \\
\text { Véronique }\end{array}$ & France & $\begin{array}{l}\text { Director of VAB- } \\
\text { Nutrition }\end{array}$ & $\begin{array}{l}\text { A consulting company that works } \\
\text { for the UPP industry }\end{array}$ \\
\hline Fulgoni III, Victor & USA & Nutrition Impact & $\begin{array}{l}\text { A business that "helps companies } \\
\text { market their food products by }\end{array}$ \\
\hline
\end{tabular}




\begin{tabular}{|l|l|l|l|}
\hline & & & $\begin{array}{l}\text { promising drug-like benefits" } \\
\text { (Source Watch 2018) }\end{array}$ \\
\hline Keast, Debra & USA & $\begin{array}{l}\text { President of Food \& } \\
\text { Nutrition Database } \\
\text { Research } \\
\text { \& sub-contracted by } \\
\text { the above-mentioned } \\
\text { Nutrition Impact }\end{array}$ & $\begin{array}{l}\text { For Nutrition Impact, Debra Keast } \\
\text { conducted research funded by a } \\
\text { UPP industry actor }\end{array}$ \\
\hline Leveille, Gilbert & USA & $\begin{array}{l}\text { UPP industry } \\
\text { consultant }\end{array}$ & Unknown \\
\hline Romero, Jairo & Colombia & $\begin{array}{l}\text { President of the } \\
\text { Asociación } \\
\text { Latinoamericana y } \\
\text { del Caribe de Ciencia } \\
\text { y Technologia de } \\
\text { Alimentos } \\
\text { (ALACCTA) }\end{array}$ & $\begin{array}{l}\text { A regional association of food } \\
\text { technologists, including industry } \\
\text { actors (ALACCTA 2018) }\end{array}$ \\
\hline Schmidt, David & USA & $\begin{array}{l}\text { President and CEO } \\
\text { of the International } \\
\text { Food Information } \\
\text { Council (IFIC) }\end{array}$ & $\begin{array}{l}\text { IFIC is supported by several UPP } \\
\text { industry actors, including: Abbott } \\
\text { Nutrition, the Coca-Cola } \\
\text { Company, Danone North America, } \\
\text { Ferrero USA, General Mills, Inc., } \\
\text { Mondelēz International, PepsiCo, } \\
\text { Red Bull North America, Subway, } \\
\text { Yum! Brands (International Food } \\
\text { Information Council 2018) }\end{array}$ \\
\hline Shelke, Kantha & USA & $\begin{array}{l}\text { Founder and } \\
\text { principal of Corvus } \\
\text { Blue }\end{array}$ & $\begin{array}{l}\text { ackood science and consumer } \\
\text { (Shelke 2018) }\end{array}$ \\
\hline
\end{tabular}

Most of these individuals were based in the USA, reflecting the location of publication of most of the materials retrieved. None of these authors directly worked for the UPP industry. Instead, they worked for trade associations, did consultancies for the UPP industry, etc. These indirect relationships mean that it might be more complicated to identify these industry affiliations in the scientific literature.

\section{Conflicts of interest declared and not declared}

In addition to these individuals who worked with the UPP industry, we identified many conflicts of interests (COI) for other individuals. Some of these conflicts were declared, but many other links with the UPP industry were not, and only identified through additional searches.

First, our Web of Science search yielded 1,734 publications authored by 26 of the 38 individuals identified above. We removed from our searches the seven individuals who worked directly with the food industry and had no known academic affiliation; a further four individuals did not feature in the results of this search because either their publications were not indexed on Web of Science or, when indexed, the metadata did not include their academic affiliations, which prevented us from ensuring that we had identified the right individual. Finally, there was one person with no known affiliation, D. Schnakenberg. In that case, we could not run a search for him, as there could have been several people with the same name on Web of Science and we had no criteria to identify the right one. 
These Web of Science searches confirmed our findings from our Google searches, and provided us with a deeper insight into the relationships between individuals and the UPP industry. They revealed that two more individuals had relationships with this industry (R. MacDonald and I. Souchon). This means that, in total, our analyses revealed that 33 of the 38 individuals who have criticised NOVA had relationships with the UPP industry. Among the five individuals (in italics in Table 1) for which we found no evidence of a relationship with the UPP industry, two were recent graduates in nutrition and we could not find information online for another individual, as stated above.

Below, we analyse the resulting funding patterns and co-authorship networks from our Web of Science searches. Figure 1 presents all components of the network of relationships between individuals who have criticised NOVA and the UPP industry. 


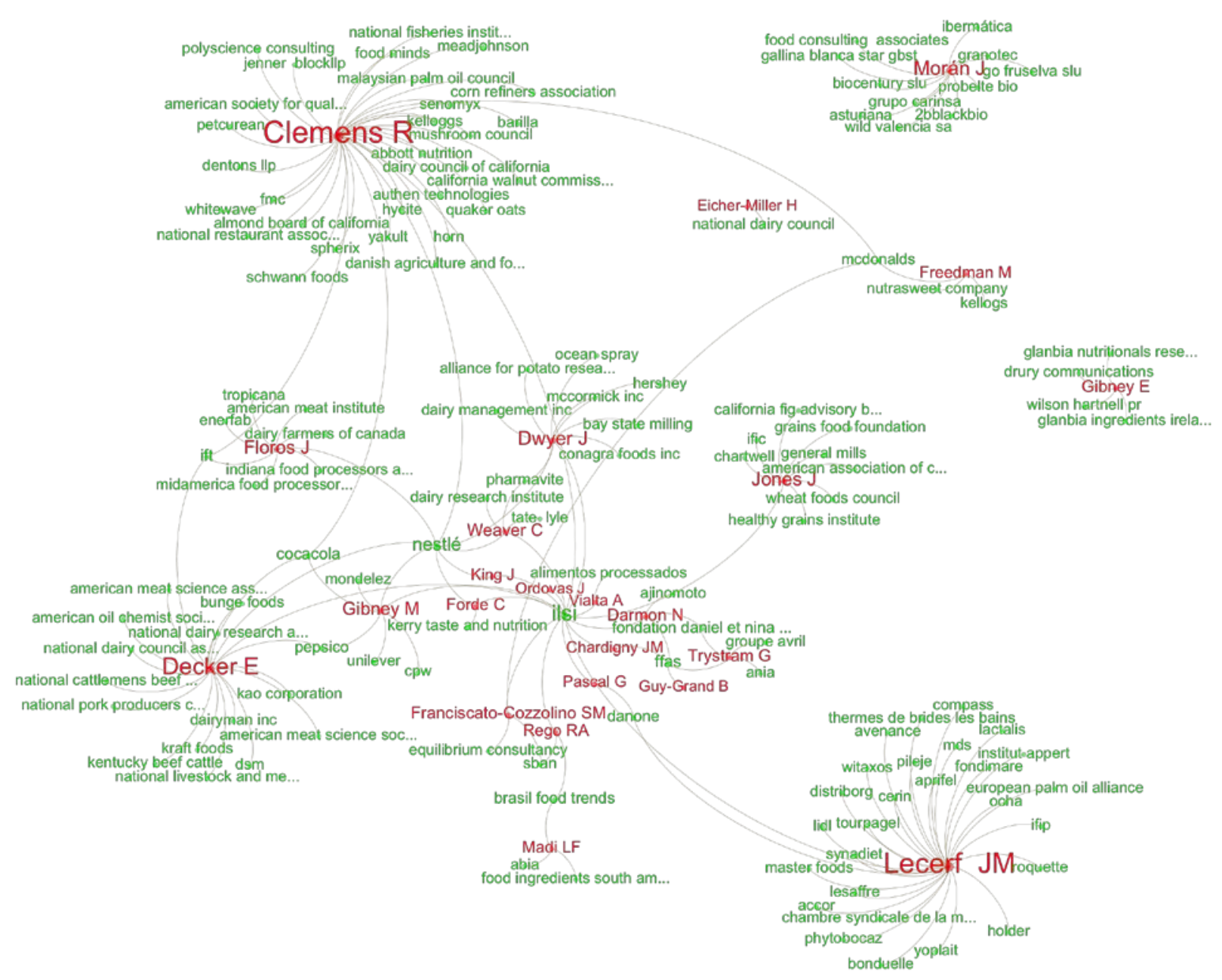

Figure 1. Two-mode network depicting ties between individuals and companies in the UPP industry.

Nodes are sized by degree centrality (total number of connections). Individuals' names are in red and UPP industry affiliated actors are in green. Layout algorithm optimised to decrease label and node overlap. 
The most central researchers in this network are JM. Lecerf, E. Decker and R. Clemens, all of whom have ties to the most central UPP industry organisation in this network: the International Life Science Institute (ILSI). In fact, at least half (20/38) of the individuals criticising NOVA had relationships, at some point, with ILSI, a scientific organisation funded by the food industry (International Life Science Institute 2016). ILSI was once described as a "corporate lobby group" and its activities were considered to be in conflict with public health interests (Corporate Europe Observatory 2012). There is evidence that ILSI had strong ties with the tobacco industry and it was criticised for its lobbying against tobacco control efforts (World Health Organization 2001). In 2016, the Guardian reported that ILSI was also funded by the pesticides industry (Nelsen 2016). ILSI was "founded in Washington in 1978 by the Heinz Foundation, Coca-Cola, Pepsi-Cola, General Foods, Kraft (owned by Philip Morris) and Procter \& Gamble” (Boseley 2003). The most recent data available show that, in 2015, ILSI was supported by dozens of transnational companies, including Cargill, Coca Cola, Danone, General Mills, Mc Donald's, Mondelez, PepsiCo, and Unilever (International Life Science Institute 2016). Some of the individuals who criticised NOVA published reports or presented their work at ILSI events, but others had more substantial roles in the organisation. C. Weaver is the chair of the ILSI board of trustees and chair of the ILSI board publications committee (International Life Science Institute 2018a). At ILSI Europe, M. Gibney is a member of the board of directors and G. Pascal is a member of the nominations committee (International Life Science Institute 2018b).

Another interesting feature depicted in the network is the fact that the two most central actors, JM. Lecerf and R. Clemens, only share one connection in common (ILSI), but are both extremely well connected to corporations in their respective countries. In France, JM. Lecerf works at the Institut Pasteur de Lille, an institution that has had ties with such actors in the UPP industry as Coca Cola and Danone (Mialon and Mialon 2017; Mialon and Mialon 2018). In the USA, R. Clemens was a scientific Advisor for Nestlé USA for more than two decades (PolyScience consulting 2018). He provided consulting services or served on the advisory council of, among others, the Corn Refiners Association, the Dairy Council of California, McDonalds, the National Restaurant Association and Quaker Oats (Clemens et al. 2016).

In order to gauge the extent to which these individuals were embedded in prolific research communities, we sought to map their co-authorship networks from the searches we conducted in Web of Science, using the individual's name and their current academic affiliation. In total, these researchers were involved in 1,734 publications between 1998 and 2018. In Figures 2 and 3, we depict their co-authorship network, that is, we represent graphically the co-authorship links between any of the listed authors in the 1,734 publications we retrieved from Web of Science (that is, publications in which at least one of the 26 researchers from our sample was involved in). In Figure 2, the blue names represent the authors in our sample criticising NOVA and the nodes in red represent their co-authors. The edges are weighted by the number of published papers between any pair of co-authors (thicker lines indicate a higher number of co-authored papers). Overall, the researchers seemed scattered between different research groups, with one of them very close to the core of the network where a large research community proliferates. Apart from the core, the subgroups in the network with higher density (higher concentration of ties) are actually formed around where the researchers of interest are located. 


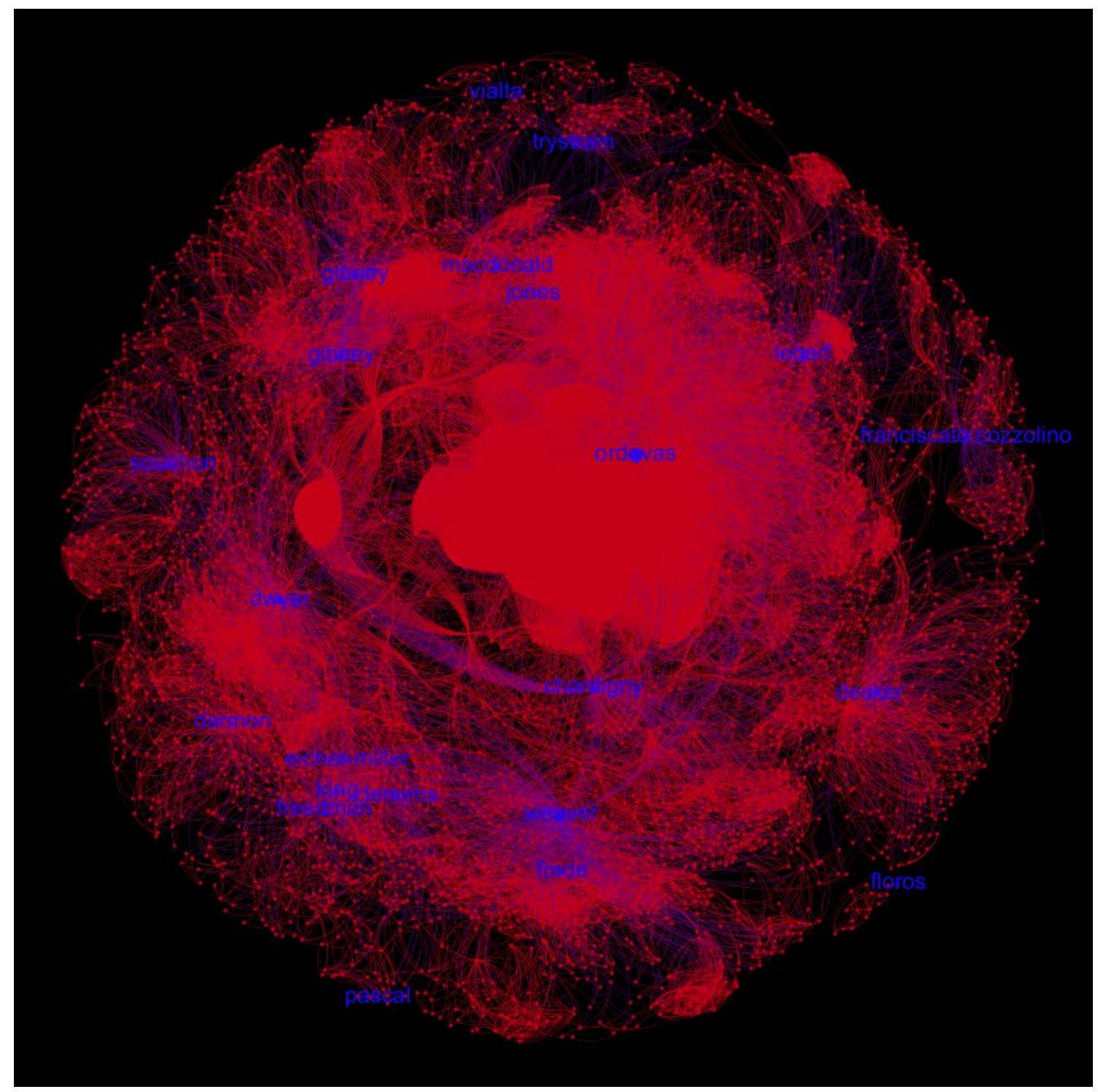

Figure 2. One-mode co-authorship network.

Nodes taking the form of circles represent authors, and are linked by edges when they co-author a paper. The edges are weighted by the number of publications co-authored by any pair of authors (the thicker the edges, the higher the number of publications). Blue names identify the 26 authors in our sample, red circles identify their co-authors.

In Figure 3, we illustrate how the network is organised in different subgroups by colouring the different partitions of the graph, following an algorithm that iteratively disconnects edges from the network based on edge betweenness. 


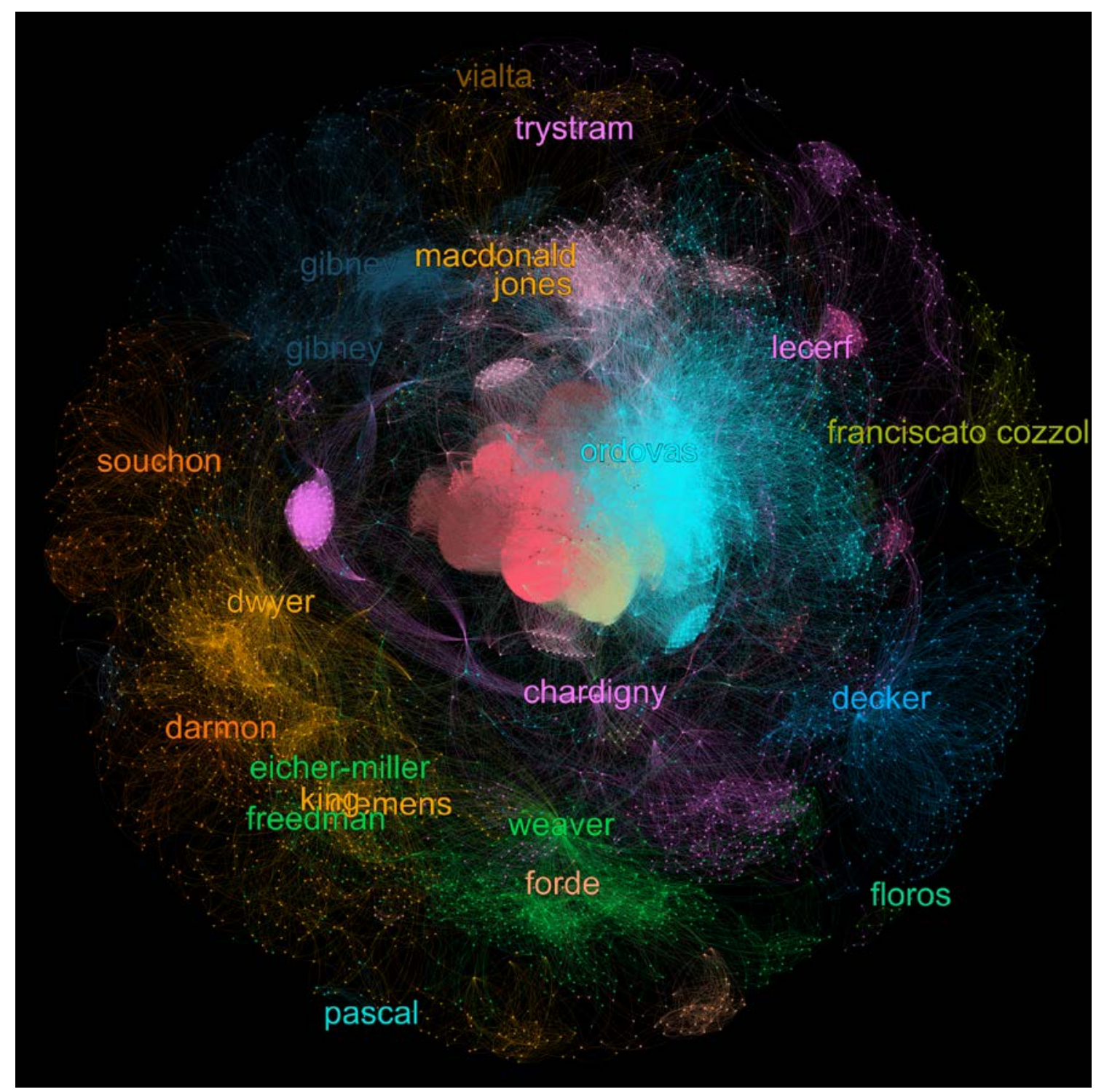

Figure 3. Co-authorship network, where nodes are authors tied to each other when sharing authorship in the same scientific publication.

The network is divided in coloured factions/clusters, which represent different research communities in the network. The authors in our sample have label tags with their surname and are coloured according to the research community they belong to.

The subgroups coloured in Figure 3 can have different bases: some are organised geographically (language might be influential as well), others are organised around research topics and others around academic institutions. We labelled and coloured the nodes corresponding to the researchers of interest in our sample, according to which community in the network they belong to.

Lastly, we attempted to recreate Figure 1 using only the funding acknowledgement/COI statement statements in the 1,734 publications we retrieved from the Web of Science search. We manually inspected each funding acknowledgement/COI statement and identified companies who worked in the food and beverage industry at large, irrespective of whether the majority of their profits were drawn from UPP. Comparing Figure 1 with Figure 4, we quickly realised that the funding statements in published research 
underreported the ties between researchers and the UPP industry. The reasons for this are unclear. On the one hand, researchers may deliberately fail to report their relationships with industry. On the other, some journals' guidelines on what constitute a COI may not warrant the disclosure of such ties. Nonetheless, these ties to industry are more often than not invisible to the readers of said research, and exercises such as this one bring clarity to a complex web of relationships that can have a detrimental impact on how science advances in public health nutrition. 


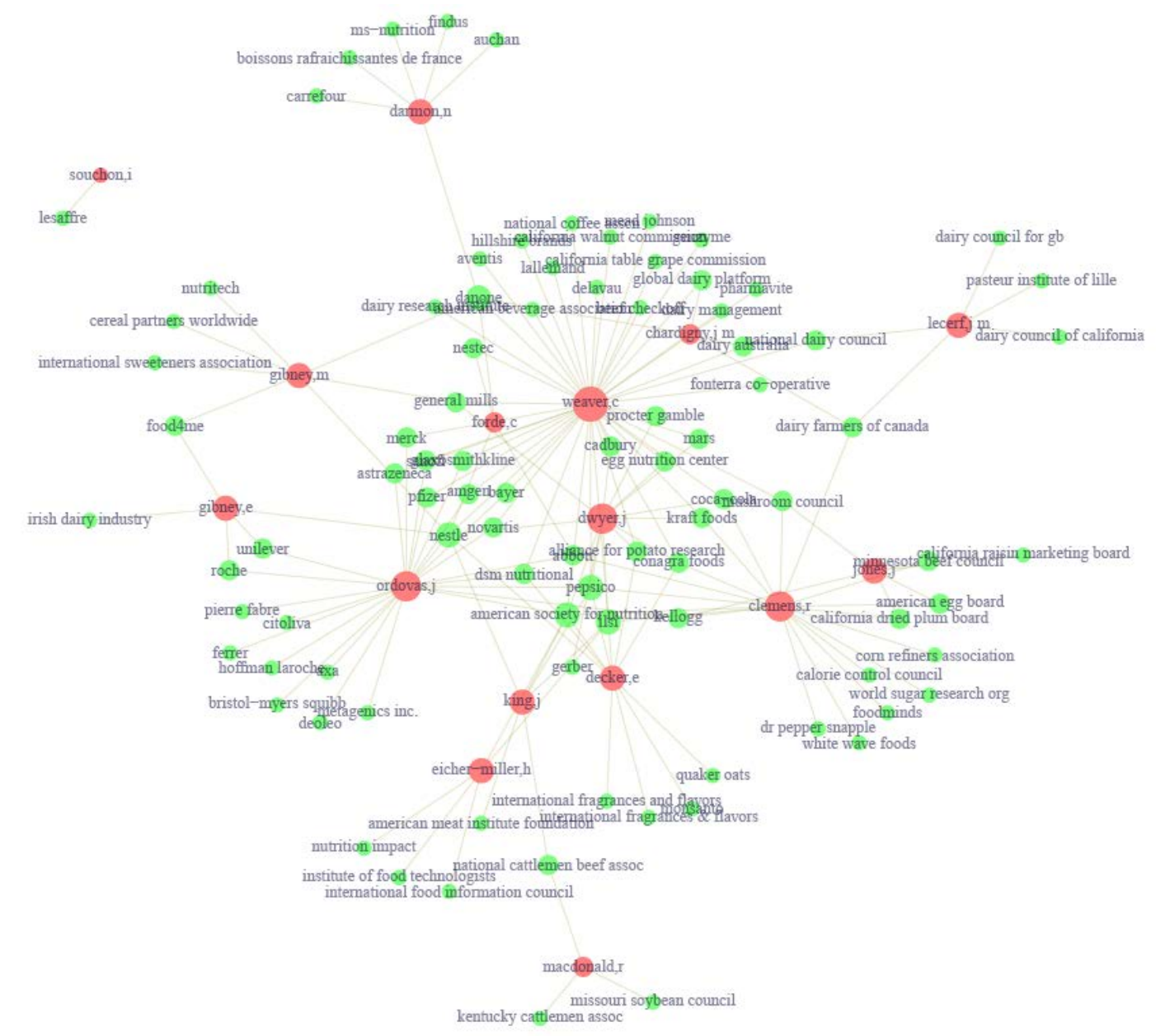

Figure 4. Two-mode network depicting ties between individuals and actors in the UPP industry, as per the funding statements in the 1,731 publications retrieved from our Web of Science search.

Nodes are sized by degree centrality (total number of connections). Red circles represent individuals. Green circles represent industry actors. Layout algorithm optimised to decrease label and node overlap. 
This brief network analysis of researchers' ties to industry brought us two important insights: (1) the researchers we studied are very well connected, heavily published, and have the ability to influence many scientific forums; (2) many of their ties to UPP industry are underreported in their published work.

\section{Platforms where NOVA was criticised and relationships with the UPP industry}

Finally, we identified that many organisations who hosted/published a criticism of the NOVA classification also had relationships with the UPP industry.

We found one document that was published in the Journal of the Academy of Nutrition and Dietetics (AND). In 2013, Simon, a lawyer, showed that the AND was sponsored by industry actors such as General Mills and Kellogg and the association presented a list of approved continuing education providers in which Coca-Cola, Kraft Foods, Nestlé, and PepsiCo were included (Simon 2013). The UPP industry (e.g.; the Corn Refiners Association, Nestlé) was also involved in the annual event of the association, presenting their products at the exhibition and sponsoring scientific sessions (Simon 2013). Many of the speakers at these events had ties with the industry, not necessarily disclosed to the participants (Simon 2013). It was suggested that these relationships between the AND and the industry might have discouraged the association from supporting effective (but controversial for the industry) public health nutrition policies (Simon 2013).

Several documents were published in the journals of the American Society for Nutrition (ASN) (and one symposium questioning the role of processing was hosted by the ASN). Here again, in 2015, Simon, described the relationships between the ASN and the UPP industry (Simon 2015). Simon listed the partners of the ASN, many of which were from the UPP industry, and explained that industry actors such as PepsiCo sponsored sessions at the ASN annual event and other meetings (Simon 2015). In this report, Simon discussed one ASN publication discrediting the NOVA classification, and how this might be linked to the fact that the ASN had strong ties with the UPP industry (Simon 2015). Three years after the publication of this report, the ASN is still partnering with many major actors in the UPP industry: the General Mills Bell Institute of Health and Nutrition, the Kellogg Company, Mars Inc., Nestle Nutrition, PepsiCo, the Coca Cola Company, the Dannon Company (US subsidiary of Danone), the Sugar Association, and Unilever (American Society for Nutrition 2018a). In addition, the society provides industry-sponsored scholarships to students in nutrition (American Society for Nutrition 2018b). One ASN symposium was sponsored by the American-based Institute of Food Technologists (IFT) and the International Food Information Council (IFIC). IFIC has been introduced earlier in this manuscript, in Table 1. The outcomes of this ASN symposium were published in an ASN journal, and one of the authors of this document was a former member of the IFT Board of Directors. In addition to this symposium, the IFT also published a series of videos included in the materials we collected for this study questioning the NOVA classification. The IFT has had numerous relationships with the UPP industry. As of August 2018, its current president was employed by DuPont Nutrition and Health, its treasurer was "a seasoned industry veteran with more than 21 years of food and beverage experience” (Institute of Food Technologists 2018), and many of its board members worked with this industry. From our searches online, we concluded that the IFT was not transparent enough about its industry partners on its websites.

In the United States of America again, two documents were presented as part of a cereal industry-sponsored event called "Cereals 17", organised by AACC International (AACC 
International 2018a). AACC is an association of "scientists and food industry professionals” (AACC International 2018b).

In France, an event was organised at the French Academy of Agriculture to criticise the NOVA classification. From our searches, the only relationship that we could establish between the Academy and the industry was through the declaration, on the website of the academy: "The French Academy of Agriculture is, notably, in working relations with (...) most professional organisations in the agriculture and food sectors, as well as with their technical centres” (our translation) (Académie d’Agriculture de France 2018a).

In France again, a review and an editorial were published in 2018 that discredited the NOVA classification. We previously introduced the conflicts of interest of the researchers who wrote these documents. In addition, the scientific journal "les Cahiers de Nutrition et Diététique", in which these documents were published, also had links with the food industry. We found that three of its editorial board members directly worked for the food industry: one, cited earlier in this manuscript, worked for VAB-Nutrition, and another for Linkup (LinkUp Factory 2018), which are two consulting firms for the food industry, and the third person worked for Nestlé (Cahiers de Nutrition et de Diététique 2018).

In Belgium, the Belgian Nutrition Society hosted a session at its annual conference, where M. Gibney presented his rebuttal of the NOVA classification (Belgian Nutrition Society 2018a). The conference was sponsored by actors in the UPP industry such as Yakult and the Belgian Fédération de l’Industrie Alimentaire (FEVIA) (Food Industry Federation) (Belgian Nutrition Society 2018b). It is important to note that counter-arguments were also presented during the session, with authors of NOVA publications sharing their own research findings (Belgian Nutrition Society 2018a).

In Chile, a presentation criticising the NOVA classification was given at IFAN, a "public private programme, created from an alliance between the food industry and academia" (IFAN 2018). IFAN is a consortium of partners, including actors in the UPP industry such as the Consorcio de Cereales Funcionales (CCF) (Functional Cereal Consortium) and Granotec (Red agricola 2017).

Finally, in Brazil, three employees of the Instituto de Tecnologia de Alimentos (ITAL) (Institute of Food Technology) produced materials questioning the NOVA classification. ITAL is a public organisation from the State of São Paulo, closely linked to the UPP industry, as stated on its website: "For companies, ITAL offers consulting, training and analysis services, with guarantee of exemption and competence. According to its strategic plan, ITAL has oriented its activities towards the generation of innovation projects, investing in the study of trends in the food sector, establishing partnerships and forming collaborative networks, involving the private sector and other stakeholders of the food sector” (Instituto de Tecnologia de Alimentos 2018a). ITAL's project “Brazil Processed Food 2020" was conducted in partnership with the Associação Brasileira das Indústrias da Alimentação (ABIA) (Brazilian Association of Food Industries), one of the largest food industry trade association in the country (Instituto de Tecnologia de Alimentos 2015). A long list of other trade associations were also involved in the project (Instituto de Tecnologia de Alimentos 2015). ITAL's website called "Processed Foods" was created under this project, and its technical committee includes members from the UPP industry, such as ABIA, IFIC (mentioned above) and ILSI Brazil (Instituto de Tecnologia de Alimentos 2018b). This website questioned the NOVA classification.

We identified four journals in which a criticism of NOVA was published and that had no relationship with the UPP industry, to our knowledge: "Public Health Nutrition", "Medecine des maladies metaboliques", "Food and Nutrition Sciences”, and "Nutrients". 
The International Committee of Medical Journal Editors (ICMJE) explained that "a growing number of entities are advertising themselves as "scholarly medical journals" yet do not function as such. These journals ("predatory” or "pseudo-journals") accept and publish almost all submissions and charge article processing (or publication) fees, often informing authors about this after a paper's acceptance for publication. They often claim to perform peer review but do not and may purposefully use names similar to well established journals" (International Committee of Medical Journal Editors 2018). One of the article we identified for our study was published in such a predatory journal, "EC Nutrition” (“Beall’s List of Predatory Journals and Publishers - Publishers” 2018).

\section{Discussion}

This study examined the relationships between the individuals/organisations that criticised the NOVA classification and the UPP industry. Our analysis showed that there is a lack of transparency and a potential bias from the individuals and organisations that have criticised these types of food and beverage classifications. 33 individuals (of the 38 that we have identified) had relationships with the UPP industry. Seven individuals who criticised NOVA directly worked with the UPP industry. Some others had either declared or hidden COI with this industry. It is concerning that a thorough review of the publication record of these individuals does not paint a complete picture of what their ties to industry are and how these can materialise in damaging conflicts of interest.

Moreover, some organisations that hosted or presented criticism of NOVA, such as the Academy of Nutrition and Dietetics (AND) in the USA, the Instituto de Tecnologia de Alimentos (ITAL) in Brazil, or the scientific journal "les Cahiers de Nutrition et Diététique" in France, also had relationships with the UPP industry.

Among the 32 materials that we found, there were a limited number of peer-reviewed scientific articles (7/32). However, scientific journals seemed to be used as a credible platform for disseminating this criticism, through letters, commentaries, report from meetings, etc. Other media such as videos and a website were also used. Each had a specific audience (e.g., scientists and the public).

There is a need for further investigations of the relationships between the employers of individuals who worked in academia and the UPP industry.

Our study has a number of limitations: it was not meant to be a systematic exercise, and was not exhaustive but rather presented the relationships between individuals/organisations that criticised NOVA and the UPP industry. Our intention was neither to assess the content of the criticism, nor to refute it. This might be the subject of further analyses. In addition, we did not limit our searches to a certain date in the past, and some might argue that there is a period after which a COI has no capacity to influence an individual any more. This also means that some individuals might only have declared their relationships with the UPP industry for the most recent years and not for their entire career. In the future, more searches could be conducted for all actors, those who have praised and those who have criticised this classification.

In conclusion, there are many relationships between individuals who criticised NOVA and the UPP industry, many of which are probably unknown to the public. This creates a COI and risks influencing the decisions of public health nutrition professionals and policy makers in ways favourable to the UPP industry and harmful to public health. In addition, this study shows that there is a need for greater transparency in research. Many conflicts 
of interest that we found in this study were not declared. This could have a detrimental impact on the how science advances in public health nutrition.

\section{Acknowledgments}

The authors would like to acknowledge Neha Khandpur for copy editing a draft version of the manuscript. 


\section{References}

AACC International. 2018a. "Cereals 2017." https://www.aaccnet.org/MEETINGS/ARCHIVE/2017/Pages/default.aspx.

_. 2018b. “About AACC.” https://www.aaccnet.org/about/Pages/default.aspx.

Académie d’Agriculture de France. 2018a. “Autres Partenaires.” https://www.academieagriculture.fr/academie/rayonnement-partenariat/autres-partenaires.

. 2018b. "Des Matières Premières Agricoles Aux Aliments : Quel Impact Des Procédés de Transformation Sur La Qualité de L’alimentation?” May 2. https://www.academie-agriculture.fr/actualites/academie/seance/academie/desmatieres-premieres-agricoles-aux-aliments-quel-impact-des.

American Society for Nutrition. 2018a. "Sustaining Partners." https://nutrition.org/sustaining-partners/. . 2018b. “Awards.” https://nutrition.org/about-asn/awards/.

“Beall's List of Predatory Journals and Publishers - Publishers.” 2018. Accessed September 11. https://beallslist.weebly.com/.

Belgian Nutrition Society. 2018a. "Ultra-processed Foods in Human Nutrition and Health - Belgian Nutrition Society Eight Annual Meeting, May 4th , 2018 - Proceedings.”

—. 2018b. "Events - Belgian Nutrition Society." https://www.belgiannutritionsociety.be/events/.

Boseley, Sarah. 2003. "WHO' ' 'Infiltrated by Food Industry.” The Guardian.

Cahiers de Nutrition et de Diététique. 2018. "Cahiers de Nutrition et de Diététique Editorial Board.” https://www.journals.elsevier.com/cahiers-de-nutrition-et-dedietetique/editorial-board.

Chardigny. 2018. “Alimentation, Santé Publique, Étiquetage, Où Va-t-on ? [Editorial].” Cahiers de Nutrition et de Diététique 53 (3): 123-4.

Clemens, Roger A., Julie M. Jones, Mark Kern, Soo-Yeun Lee, Emily J. Mayhew, Joanne L. Slavin, and Svetlana Zivanovic. 2016. "Functionality of Sugars in Foods and Health.” Comprehensive Reviews in Food Science and Food Safety 15 (3): 433470. doi:10.1111/1541-4337.12194.

Corporate Europe Observatory. 2012. “The International Life Science Institute, a Corporate Lobby Group.”

Darmon, Nicole. 2009. “The Good, the Bad, and the Ultra-processed. [Letter].” Public Health Nutrition 12 (10): 1967-8; author reply 1968. doi:10.1017/S1368980009991212.

Decker. 2013. "Processed Food Makes Our Lives Better (Video)". presented at the Institute of Food Technologists, March.

Dwyer, Johanna T., Victor L. Fulgoni, Roger A. Clemens, David B. Schmidt, and Marjorie R. Freedman. 2012. "Is 'Processed' a Four-Letter Word? The Role of Processed Foods in Achieving Dietary Guidelines and Nutrient Recommendations." Advances in Nutrition 3 (4): 536-548. doi:10.3945/an.111.000901. 
Eicher-Miller. 2013. “One Size Doesn't Fit All When It Comes To Processed Foods (Video)”. presented at the Institute of Food Technologists, March.

Eicher-Miller, Heather A, Victor L Fulgoni, and Debra R Keast. 2012. “Contributions of Processed Foods to Dietary Intake in the US from 2003-2008: a Report of the Food and Nutrition Science Solutions Joint Task Force of the Academy of Nutrition and Dietetics, American Society for Nutrition, Institute of Food Technologists, and International Food Information Council.” The Journal of Nutrition 142 (11): 2065S-2072S. doi:10.3945/jn.112.164442.

2015a. "Energy and Nutrient Intakes from Processed Foods Differ by Sex, Income Status, and Race/Ethnicity of US Adults." Journal of the Academy of Nutrition and Dietetics 115 (6): 907-18.e6. doi:10.1016/j.jand.2014.11.004.

2015b. "Processed Food Contributions to Energy and Nutrient Intake Differ Among US Children by Race/Ethnicity.” Nutrients 7 (12): 10076-10088. doi:10.3390/nu7125503.

Fiolet, Thibault, Bernard Srour, Laury Sellem, Emmanuelle Kesse-Guyot, Benjamin Allès, Caroline Méjean, Mélanie Deschasaux, et al. 2018. "Consumption of Ultraprocessed Foods and Cancer Risk: Results from NutriNet-Santé Prospective Cohort.” BMJ (Clinical Research Ed.) 360 (February): k322. doi:10.1136/bmj.k322.

Floros. 2013. "Everything Is Processed (Video)". presented at the Institute of Food Technologists, March.

Food and Agriculture Organization of the United Nations. 2016. "Food-based Dietary Guidelines - Uruguay.” http://www.fao.org/nutrition/education/food-baseddietary-guidelines/regions/countries/uruguay/en/.

Gibney, Michael J. 2018. "Ultra-processed Foods: Definitions and Policy Issues.” Current Developments in Nutrition, September. doi:10.1093/cdn/nzy077.

Gibney, Michael J, Ciarán G Forde, Deirdre Mullally, and Eileen R Gibney. 2017. "Ultraprocessed Foods in Human Health: a Critical Appraisal. [Commentary].” The American Journal of Clinical Nutrition 106 (3): 717-724. doi:10.3945/ajcn.117.160440.

Guy-Grand. 2018. “Analyse D’articles: Aliments «ultra-transformés» et Cancer.” Cahiers de Nutrition et de Diététique 53 (April): 74-5.

Haut Conseil de la Santé Publique. 2018. “Avis Relatif Aux Objectifs de Santé Publique Quantifiés Pour La Politique Nutritionnelle de Santé Publique (PNNS) 20182022.”

IFAN. 2018. “IFAN - Quienes Somos.” http://ifan.cl/quienes-somos/.

Institute of Food Technologists. 2018. “Scott Lineback' ' - IFT.org.” Accessed December 3. http://www.ift.org/About-Us/Our-Leadership/Scott-Lineback.aspx.

Instituto de Tecnologia de Alimentos. 2015. "SAA e ABIA Firmam Convênio Para o Desenvolvimento Do Estudo Brasil Processed Food 2020 Idealizado Pelo ITAL.” http://www.ital.sp.gov.br/noticias.php?not_id=661.

2018a. "Sobre o ITAL.” http://www.ital.sp.gov.br/ital.php.

. 2018b. "Alimentos Processados: O Comitê Técnico-Científico Do Website

"Alimentos Processados.” http://www.alimentosprocessados.com.br/comite.php. 
—. 2018. "Alimentos Processados | MITO: A Existência de Alimentos Ultraprocessados.” Accessed December 25. http://www.alimentosprocessados.com.br/mitos-fatos-processamentoultraprocessados.php.

International Committee of Medical Journal Editors. 2018. Recommendations for the Conduct, Reporting, Editing, and Publication of Scholarly Work in Medical Journals - Updates Dec 2018. International Committee of Medical Journal Editors.

International Life Science Institute. 2016. “2015 Member and Supporting Companies.” http://ilsi.org/wp-content/uploads/2016/01/Members.pdf.

—. 2018a. "About - Leadership \& Financial Support.” http://ilsi.org/about/leadership-support/.

— . 2018b. “About ILSI Europe.” http://ilsi.eu/about-us/.

Jones, and Clemens. 2017a. Cereals 17 Symposium - Food Selection According to Food Processing: Fabulous or Flawed? Processed and Ultraprocessed Foods Defined - An Alice in Wonderland Question?

2017b. Cereals 17 Symposium - Food Selection According to Food Processing: Fabulous or Flawed? Introductory Brain Teaser for the Cereal Chemist - How Do We Categorize Processedand Ultraprocessed Foods?

Jones, Julie Miller. 2018. "Food Processing: Criteria for Dietary Guidance and Public Health?" The Proceedings of the Nutrition Society, September, 1-15. doi:10.1017/S0029665118002513.

Lecerf, J M. 2018. "Les Aliments Hyper-transformés : Un Nouveau Concept Discuté.” Médecine Des Maladies Métaboliques 12 (4): 381-386. doi:10.1016/S19572557(18)30107-X.

LinkUp Factory. 2018. "La LinkUp Factory Fière D’accompagner Ferrero Dans Le Combat Pour Une Huile de Palme Durable! - Linkup Factory." http://www.lalinkupfactory.fr/linkup-factory-fiere-daccompagner-ferrerocombat-huile-de-palme-durable/.

Madi, Luis, and Raul Amaral Rego. 2015. "Comunicação Rápida: Brasil Processed Food 2020: Um Projeto Em Defesa Da Industrialização de Alimentos.” Brazilian Journal of Food Technology 18 (4): 337-339. doi:10.1590/1981-6723.1216.

Martins, Sanchez Oliveira Jensen, and Franciscato Cozzolino. 2016. "Comparison of Child Lunch Meals in Brazil.” Food and Nutrition Sciences, 262-72.

Mialon, M, C Julia, and S Hercberg. 2018. "The Policy Dystopia Model Adapted to the Food Industry: The Example of the Nutri-Score Saga in France.” World Nutrition 9 (2): 109-120.

Mialon, M, and J Mialon. 2017. "Corporate Political Activity of the Dairy Industry in France: An Analysis of Publicly Available Information.” Public Health Nutrition In press. 2018. "Analysis of Corporate Political Activity Strategies of the Food Industry: Evidence from France.” Public Health Nutrition, July, 1-15. doi:10.1017/S1368980018001763. 
Mialon, M, B Swinburn, and G Sacks. 2015. “A Proposed Approach to Systematically Identify and Monitor the Corporate Political Activity of the Food Industry with Respect to Public Health Using Publicly Available Information.” Obesity Reviews 16 (7): 519-530. doi:10.1111/obr.12289.

Michaels, David. 2008. Doubt Is Their Product: How Industry's Assault on Science Threatens Your Health. Oxford; New York: Oxford University Press.

Ministry of Health. 2014. Dietary Guidelines for the Brazilian Population 2014.

Monteiro. 2009. "Nutrition and Health. The Issue Is Not Food, nor Nutrients, so Much as Processing." Public Health Nutrition 12 (5): 729-731. doi:10.1017/S1368980009005291.

Monteiro, C. 2011. "The Big Issue Is Ultra-processing. There Is No Such Thing as a Healthy Ultra-processed Product. [Commentary].” World Nutrition 2 (7): 333-49.

Monteiro, Cannon, Bertazzi Levy, Claro, and Moubarac. 2012. "The Food System. Ultraprocessing. The Big Issue for Nutrition, Disease, Health, Well-being. [Commentary].” World Nutrition 3 (12): 527-69.

Monteiro, Cannon, Levy, Moubarac, Jaime, Martins, Canella, Louzada, and Parra. 2016. "View of NOVA. The Star Shines Bright." World Nutrition 7: 1-3.

Monteiro, Cannon, Moubarac, Levy, Louzada, and P C Jaime. 2018a. “The UN Decade of Nutrition, the NOVA Food Classification and the Trouble with Ultraprocessing." Public Health Nutrition 21 (1): 5-17. doi:10.1017/S1368980017000234.

Monteiro, Cannon, Moubarac, Levy, Louzada, and Patrícia C Jaime. 2018b. "Ultraprocessing. An Odd 'Appraisal'.” Public Health Nutrition 21 (3): 497-501. doi:10.1017/S1368980017003287.

Moran. 2017. “Acerca de Los Sistemas de Clasificación de Alimentos y Su Racionalidadcientífica”. presented at the II $^{0}$ consejo tecnico de IFAN, March 27.

Moubarac, Jean-Claude, Diana C Parra, Geoffrey Cannon, and Carlos A Monteiro. 2014. "Food Classification Systems Based on Food Processing: Significance and Implications for Policies and Actions: A Systematic Literature Review and Assessment.” Current Obesity Reports 3 (2): 256-272. doi:10.1007/s13679-0140092-0.

Nelsen, Arthur. 2016. "UN/WHO Panel in Conflict of Interest Row over Glyphosate Cancer Risk." The Guardian,.

Oreskes, Naomi, and Erik Conway. 2011. "Merchants of Doubt: How a Handful of Scientists Obscured the Truth on Issues from Tobacco Smoke to Global Warming.” Choice Reviews Online 48 (11): -. doi:10.5860/CHOICE.48-6243.

Pan American Health Organization. 2015. Ultra-processed Food and Drink Products in Latin America: Trends, Impact on Obesity, Policy Implications. Washington D.C.

PolyScience consulting. 2018. “Leadership Team.” Accessed December 2. http://www.polyscienceconsulting.com/roger-clemens.html.

"Programme | The Nutrition Society - Spring Conference 2018: Nutrient-nutrient Interaction.” $2018 . \quad$ March. https://www.nutritionsociety.org/node/391/programme. 
Public Health Nutrition. 2018. "Public Health Nutrition Special Issue on Ultra-processed Foods.” Public Health Nutrition 21 (1).

Red agricola. 2017. "IFAN, El Innovador Programa de Investigación Revolucionará Industria Alimentaria.” http://www.redagricola.com/cl/ifan-innovador-programainvestigacion-revolucionara-industria-alimentaria/.

Rego, Vialta, and Madi. 2017. "The Myth of Ultra-Processed Foods.” EC Nutrition 12 (3): 148-51.

- 2018. Alimentos Industrializados. 1st ed. ITAL.

Romero. 2017. “Comentarios Al Proyecto de Ley 07 de 2017 Por Jairo Romero”. presented at the Audiencia publica de lacomisión séptima del senado de la republica de Colombia, October 26.

Shelke. 2013. "Processed Foods Wonderful For Women (Video)". presented at the Institute of Food Technologists, March.

Shelke, Kantha. 2018. "About - Kantha Shelke.” Accessed December 2. http://kantha.com/about/.

Simon, M. 2013. And Now a Word from Our Sponsors. Eat Drink Politics,.

- 2015. Nutrition Scientists on the Take from Big Food: Has the American Society for Nutrition Lost All Credibility? Eat Drink Politics,

Source Watch. 2018. "Nutrition Impact, LLC - SourceWatch.” Accessed December 3. https://www.sourcewatch.org/index.php/Nutrition_Impact,_LLC.

Standing Senate Committee on Social Affairs, Science and Technology. 2016. Report of the Standing Senate Committee on Social Affairs, Science and Technology: Obesity in Canada: a Whole-of-society Approach for a Healthier Canada.

Weaver, Connie M, Johanna Dwyer, Victor L Fulgoni, Janet C King, Gilbert A Leveille, Ruth S MacDonald, Jose Ordovas, and David Schnakenberg. 2014. "Processed Foods: Contributions to Nutrition.” The American Journal of Clinical Nutrition 99 (6): 1525-1542. doi:10.3945/ajcn.114.089284.

World Health Organization. 2001. "The Tobacco Industry and Scientific Groups ILSI: A Case Study.”

2004. Global Strategy on Diet, Physical Activity and Health. Geneva: World Health Organization.

2014. Global Status Report on Noncommunicable Diseases 2014. Geneva: World Health Organization. 


\section{Appendix 1}

Web of Science Core Collection Advance Search Parameters

AU = (Gibney, Eileen OR Gibney, Michael OR Madi, Luis Fernando OR Rego, Raul Amaral OR Vialta, Airton OR Forde, Ciaran OR Darmon, Nicole OR Jones, Julie OR Morán, Javier OR Pascal, Gerard OR Trystram, Gilles OR Franciscato Cozzolino, Silvia Maria OR Lecerf, Jean Michel OR King, Janet OR Ordovas, Jose OR Weaver, Connie OR Dwyer, Johanna OR Eicher-Miller, Heather OR Freedman, Marjorie OR Clemens, Roger OR Decker, Eric OR Floros, John OR Chardigny, Jean-Michel OR Guy-Grand, Bernard OR Dupont, Didier OR MacDonald, Ruth OR Martins, Carolina OR Mullally, Deirdre OR Oliveira, Natalia Sanchez OR Souchon, Isabelle

)

AND

OG $=$ (Agroparistech OR University College Dublin OR University Of California Davis OR National Institutes Of Health Nih Usa OR National University Of Singapore OR University Of Massachusetts System OR Purdue University OR Purdue University System OR University Of Southern California OR St Catherine Univ OR Tufts University OR Institut National De La Recherche Agronomique Inra OR Universidade De Sao Paulo OR Institut Pasteur Lille Or Institut National De La Recherche Agronomique INRA Or Iowa State University Or Universidade De Sao Paulo Or University College Dublin 
Appendix 2: Key messages questioning NOVA from the materials included in this study

Comments in italics were added by the authors. Bibliographic references in the quotations were removed from the original text, for better readability.

\begin{tabular}{|c|c|}
\hline Nature and details about the document & Key messages questioning NOVA \\
\hline $\begin{array}{l}\text { 3. Scientific article: Energy and Nutrient Intakes from } \\
\text { Processed Foods Differ by Sex, Income Status, and } \\
\text { Race/Ethnicity of US Adults. Journal of the } \\
\text { Academy of Nutrition and Dietetics. 2015; 15(6): } \\
\text { 907-18.e6 }\end{array}$ & $\begin{array}{l}\text { "Recommendations for a diet adhering to the DGA should continue to focus on the energy and } \\
\text { nutrient content, frequency of consumption, and serving size of individual foods rather than the } \\
\text { level of processing." (Eicher-Miller, Fulgoni, and Keast 2015a) }\end{array}$ \\
\hline $\begin{array}{l}\text { 5. Scientific article: The Myth of Ultra-Processed } \\
\text { Foods. EC Nutrition. 2017; 12(3): 148-51 }\end{array}$ & $\begin{array}{l}\text { "There is no practical sense in trying to classify foods based on the degree of processing, since the } \\
\text { same food can be processed in different ways, depending on the final product intended to achieve. } \\
\text {... In general, the wide variety of food products within a single category makes it impossible to } \\
\text { use this food-classification system to guide the choice of an individual at the time of purchase, in } \\
\text { front of a shelf full of options which vary in the number and types of ingredients, presence of }\end{array}$ \\
\hline
\end{tabular}




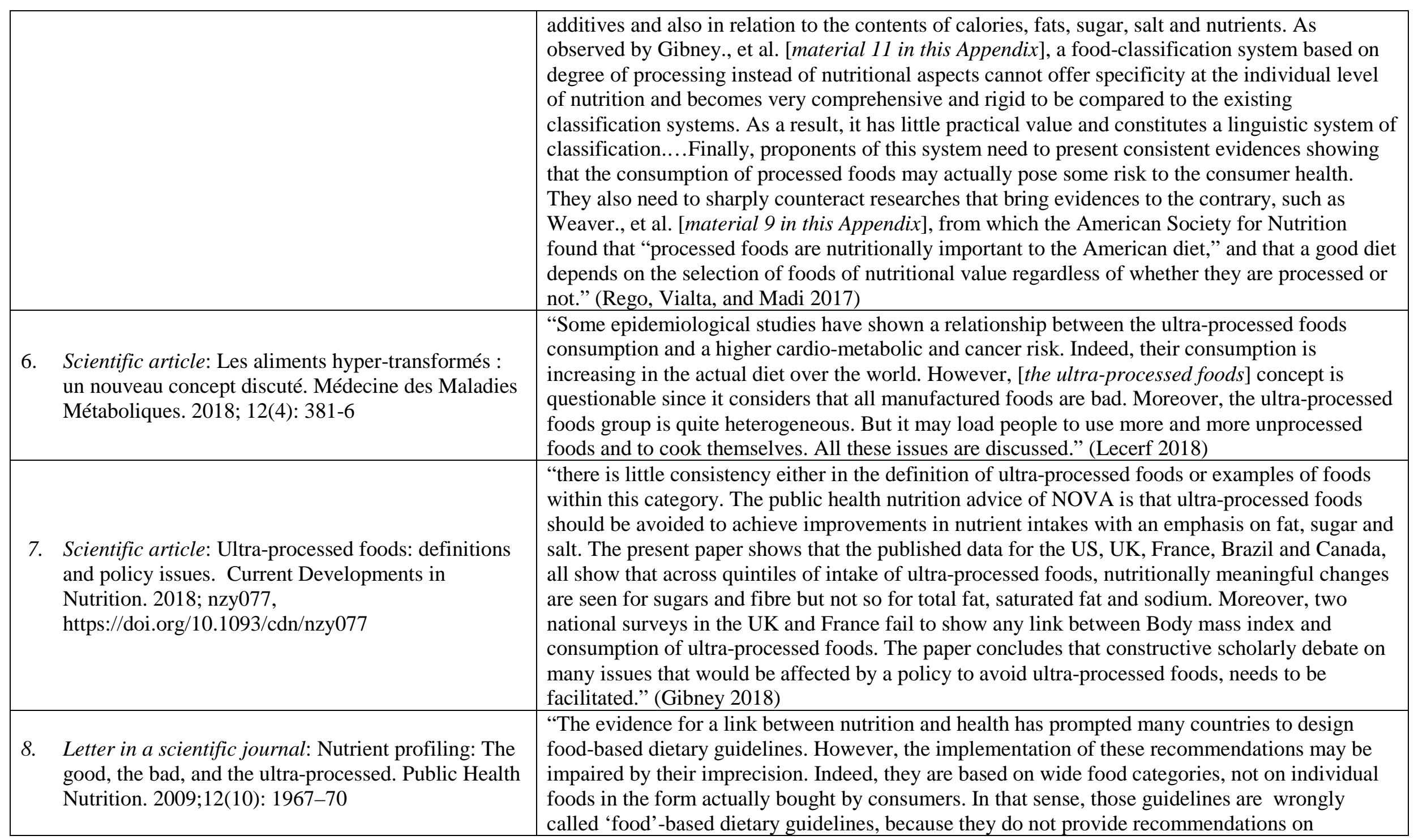




\begin{tabular}{|c|c|}
\hline & $\begin{array}{l}\text { individual foods, but on categories of foods, the definition of which is very imprecise. As a result, } \\
\text { clear recommendations on foods composed of more than one food category, such as mixed dishes } \\
\text { and snacks, are lacking. Moreover, food category-based recommendations are useless when it } \\
\text { comes to choosing between two foods that have the same selling name but different ingredient } \\
\text { and nutrient compositions and different prices. However, stigmatising a category as 'ultra- } \\
\text { processed foods' will not help to overcome these limitations, because the classification Dr } \\
\text { Monteiro proposes also lacks precision, and is therefore unlikely to be useful and operational.” } \\
\text { (Darmon 2009) }\end{array}$ \\
\hline $\begin{array}{l}\text { 9. Scientific statement in a scientific journal: Processed } \\
\text { foods: contributions to nutrition. American Journal } \\
\text { of Clinical Nutrition. 2014;99: 1525-42 }\end{array}$ & $\begin{array}{l}\text { "Both fresh and processed foods make up vital parts of the food supply. Processed food } \\
\text { contributes to both food security (ensuring that sufficient food is available) and nutrition security } \\
\text { (ensuring that food quality meets human nutrient needs). This ASN scientific statement focuses } \\
\text { on one aspect of processed foods: their nutritional impacts. Specifically, this scientific statement } \\
\text { 1) provides an introduction to how processed foods contribute to the health of populations, 2) } \\
\text { analyzes the contribution of processed foods to "nutrients to encourage" and "constituents to } \\
\text { limit" in the American diet as recommended by the Dietary Guidelines for Americans, 3) } \\
\text { identifies the responsibilities of various stakeholders in improving the American diet, and 4) } \\
\text { reviews emerging technologies and the research needed for a better understanding of the role of } \\
\text { processed foods in a healthy diet... Diets are more likely to meet food guidance } \\
\text { recommendations if nutrient-dense foods, either processed or not, are selected.” (Weaver et al. } \\
\text { 2014) }\end{array}$ \\
\hline $\begin{array}{l}\text { 11. Commentary in a scientific journal: Ultra-processed } \\
\text { foods in human health: a critical appraisal. American } \\
\text { Journal of Clinical Nutrition. 2017; 106:717-24 (and } \\
\text { corrigendum) }\end{array}$ & $\begin{array}{l}\text { "This commentary challenges many of the basic arguments of using the NOVA food } \\
\text { classification system to examine the link between food and health. We believe that there } \\
\text { is no evidence to uphold the view that UPFDs [ultra-processed foods and drinks] give rise } \\
\text { to hyperpalatable foods associated with a quasi-addictive effect and that the prevailing } \\
\text { European Union and US data fail to uphold the assertion that UPFDs, which dominate }\end{array}$ \\
\hline
\end{tabular}




\begin{tabular}{|c|c|}
\hline & $\begin{array}{l}\text { energy intake, give rise to dietary patterns that are low in micronutrients. With regard to } \\
\text { the use of the NOVA food classification in the development of food-based dietary } \\
\text { guidelines, we show that the very broad definition of UPFDs makes this impossible. } \\
\text { Finally, the available evidence does not support the view that the globalization of food is } \\
\text { the driver of increased intakes of UPFDs in low- to middle-income countries but rather } \\
\text { that this is driven by small indigenous companies. On balance, therefore, there seems to } \\
\text { be little advantage from the use of the NOVA classification compared with the current } \\
\text { epidemiologic approach, which relies on the linkage of nutrient intakes to chronic disease } \\
\text { with subsequent identification of foods that merit consideration in public health nutrition } \\
\text { strategies." (Gibney et al. 2017) }\end{array}$ \\
\hline $\begin{array}{l}\text { 12. Review of a scientific article: aliments «ultra- } \\
\text { transformés» et cancer. Cahiers de Nutrition et } \\
\text { Diététique. 2018; 53: 74-5 }\end{array}$ & $\begin{array}{l}\text { "the NOVA classification includes in the "ultra-processed" group a heterogeneous } \\
\text { patchwork of foods... the boundaries between "processed" and "ultra-processed" being } \\
\text { sometimes subjective.... we cannot draw any specific application from this work (which } \\
\text { should be replicated over a longer period) that would useful for consumers or decision- } \\
\text { makers, however, we expose all industrial foods to a condemnation by the public, which } \\
\text { would certainly be abusive (some "ultra-processed" also belonging to the middle classes of } \\
\text { Nutri-Score) [Nutri-Score is a color-coded system providing information about the } \\
\text { nutritional quality of food products, on a 5-scale color scheme, from A/Green to E/Red]." } \\
\text { [Translated from French by the first author] (Guy-Grand 2018) }\end{array}$ \\
\hline $\begin{array}{l}\text { 14. Publication resulting from an event: Is "Processed" a } \\
\text { Four-Letter Word? The Role of Processed Foods in } \\
\text { Achieving Dietary Guidelines and Nutrient } \\
\text { Recommendations. American Society for Nutrition. } \\
\text { Advances in Nutrition. 2012; 3: 536-48 }\end{array}$ & $\begin{array}{l}\text { "Ensuring that nutrient needs are met primarily through foods will also require motivating } \\
\text { consumers to eat more healthfully. This task requires addressing confusion, } \\
\text { misinformation, and negative perceptions of processed foods. Many consumers do not } \\
\text { realize that almost all foods currently consumed are processed and that food processing has } \\
\text { historically provided and will continue to provide a safe and abundant food supply that }\end{array}$ \\
\hline
\end{tabular}




\begin{tabular}{|c|c|}
\hline & $\begin{array}{l}\text { provides significant public health benefit. The mischaracterization of processed foods and } \\
\text { food technology as unnatural, unsafe, and/or nutritionally inappropriate by some health } \\
\text { professionals, advocacy organizations, and the media further makes the task of motivating } \\
\text { consumers to eat more healthfully challenging.... Consumers may object to processing and } \\
\text { novel ingredients based on aesthetic reasons or both aesthetic and nonscientific reasons. } \\
\text { [Then described contribution of processed fruits and vegetables to nutrient intake and other } \\
\text { positive aspects of food processing]" (Dwyer et al. 2012) }\end{array}$ \\
\hline $\begin{array}{l}\text { 15. Publication resulting from an event: Conference on } \\
\text { 'Nutrient-nutrient interaction' - Plenary Lecture 1- } \\
\text { Food processing: criteria for dietary guidance and } \\
\text { public health? Nutrition Society Scottish Section } \\
\text { Meeting held at the Royal College of Physicians and } \\
\text { Surgeons, Glasgow on 26-27 March 2018. } \\
\text { Proceedings of the Nutrition Society. 2018; } \\
\text { doi:10.1017/S0029665118002513 }\end{array}$ & $\begin{array}{l}\text { "NOVA categories are drawn using non-traditional views of food processing with } \\
\text { additional criteria including a number of ingredients, added sugars, and additives. } \\
\text { Comparison of NOVA's definition and categorisation of PF with codified and published } \\
\text { ones shows limited congruence with respect to either definition or food placement into } \\
\text { categories. } \\
\text { While NOVA studies associate PF with decreased nutrient density, other classifications } \\
\text { find nutrient-dense foods at all levels of processing. Analyses of food intake data using } \\
\text { NOVA show UPF provide much added sugars. Since added sugars are one criterion for } \\
\text { designation as UPF, such a proof demonstrates a tautology. Avoidance of foods deemed as } \\
\text { UPF, such as wholegrain/enriched bread and cereals or flavoured milk, may not address } \\
\text { obesity but could decrease intakes of folate, calcium and dietary fibre. Consumer } \\
\text { understanding and implementation of NOVA have not been tested. Neither have outcomes } \\
\text { been compared with vetted patterns, such as Dietary Approaches to Stop Hypertension, } \\
\text { which base food selection on food groups and nutrient contribution. NOVA fails to } \\
\text { demonstrate the criteria required for dietary guidance: understandability, affordability, } \\
\text { workability and practicality. Consumers' confusion about definitions and food } \\
\text { categorisations, inadequate cooking and meal planning skills and scarcity of resources } \\
\text { (time, money), may impede adoption and success of NOVA. Research documenting that } \\
\text { NOVA can be implemented by consumers and has nutrition and health outcomes equal to } \\
\text { vetted patterns is needed." (Jones 2018) }\end{array}$ \\
\hline $\begin{array}{l}\text { 16. Event: AACCI Events \& News: Cereals } 17 \\
\text { Symposium: Food selection according to food } \\
\text { processing: fabulous or flawed? Processed and }\end{array}$ & $\begin{array}{l}\text { "Most of the popular definitions associated with some form of food processing do not have } \\
\text { any regulatory sanction, and the popular criticism of processed foods and use of a processed } \\
\text { food categorization, which has its own criteria (e.g., subjectively defined by degree of }\end{array}$ \\
\hline
\end{tabular}




\begin{tabular}{|c|c|c|}
\hline & $\begin{array}{l}\text { Ultraprocessed Foods Defined - An Alice in } \\
\text { Wonderland Question? } 2017\end{array}$ & $\begin{array}{l}\text { processing plus other criteria), as a guide to selecting a healthful diet have become } \\
\text { contemporary topics of debate. The definitions and ideas surrounding processed food } \\
\text { categorizations will be discussed during an interactive session at the Cereals } 17 \text { meeting. } \\
\text { This first of two articles provides various definitions of processed food and shows their } \\
\text { extreme incongruence." (Jones and Clemens 2017a) }\end{array}$ \\
\hline 17. & $\begin{array}{l}\text { Event: AACCI Events \& News: Cereals } 17 \\
\text { Symposium: Food selection according to food } \\
\text { processing: fabulous or flawed? Introductory Brain } \\
\text { Teaser for the Cereal Chemist -How Do We } \\
\text { Categorize Processed and Ultraprocessed Foods? } \\
2017\end{array}$ & $\begin{array}{l}\text { "The authors argue that the }[N O V A] \text { categorization scheme raises several concerns. } \\
\text { Because processing complexity may or may not characterize a specific food in any of the } \\
\text { categories and there are many definitions of processing, this could create confusion for } \\
\text { consumers and professionals alike. Further, the lack of category standardization is } \\
\text { problematic - even in various research reports testing the NOVA classification, where some } \\
\text { researchers use three groups and others four. Additionally, there is inconsistent placement } \\
\text { of certain foods in different groups." (Jones and Clemens 2017b) }\end{array}$ \\
\hline & $\begin{array}{l}\text { Event: The Nutrition Society, Spring Conference } \\
\text { 2018: Nutrient-nutrient interaction, Plenary Lecture } \\
\text { One Avoid processed and ultra-processed foods: } \\
\text { Sound bite advice or just a sound bite. } 2018\end{array}$ & $\begin{array}{l}\text { No detail on the website of the society ("Programme | The Nutrition Society - Spring } \\
\text { Conference 2018: Nutrient-nutrient Interaction” 2018) }\end{array}$ \\
\hline 19. & $\begin{array}{l}\text { Event: Belgian Nutrition Society, Eight annual } \\
\text { meeting, May 4th, 2018: Session 1: Keynote 1: } \\
\text { Ultra-processed foods in human health: a critical } \\
\text { appraisal. } 2018\end{array}$ & $\begin{array}{l}\text { No detail on the website of the society (Belgian Nutrition Society 2018a) - see material } 11 \\
\text { in this Appendix }\end{array}$ \\
\hline
\end{tabular}




\begin{tabular}{|c|c|}
\hline $\begin{array}{l}\text { multicritère du marché français des } \\
\text { pizzas- Isabelle Souchon } \\
\text { d. La structure des aliments module leur } \\
\text { cinétique de digestion et la } \\
\text { biodisponibilité des nutriments - Didier } \\
\text { Dupont } \\
\text { e. Conclusion - Véronique Braesco }\end{array}$ & $\begin{array}{l}\text { classification should take into account many more factors than the degree of processing } \\
\text { (such as cost, environmental impact, consumer appreciation) to be truly considered } \\
\text { integrative...." } \\
\text { [Translated from French by the first author] } \\
\text { (Académie d'Agriculture de France 2018b) }\end{array}$ \\
\hline 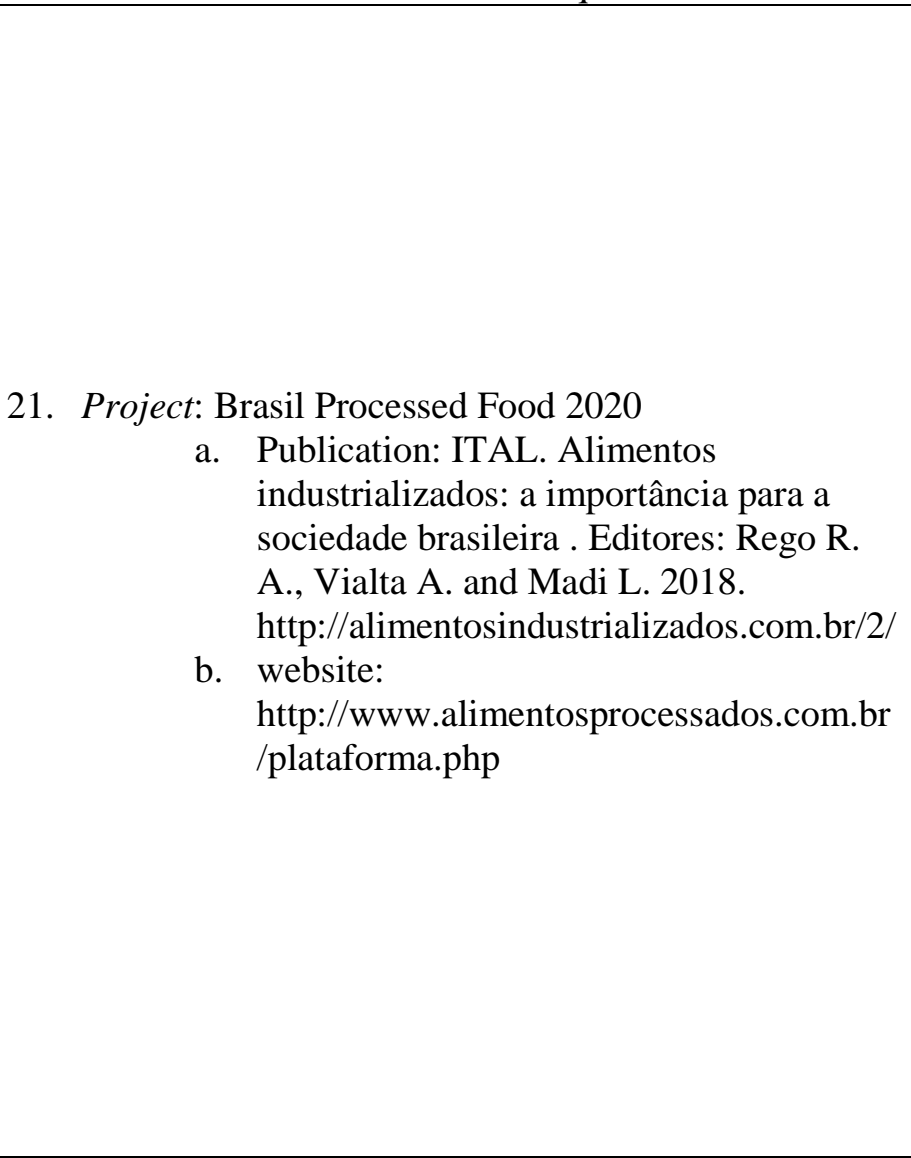 & $\begin{array}{l}\text { "Parts } 3,4 \text { and } 5 \text { [of the report] are devoted to demonstrating the inconsistencies of the } \\
\text { NOVA "classification" of food, which, in summary, recommends that consumers avoid } \\
\text { foodstuff biasedly defined as "ultraprocessed". Examples are provided to show evidence of } \\
\text { the inconsistencies and generalisations that characterise the myth of "ultra-processed food." } \\
\text { "a) From a technical point of view, there is no classification based on degrees of processing, } \\
\text { although a terminology is used and tries to lead to this understanding; b) From the statistical } \\
\text { point of view, there is no evidence that there is a significant difference between the } \\
\text { nutritional contents of processed foods from homes, restaurants and industries; c) From a } \\
\text { scientific point of view, there is no evidence that the use of convenience products adversely } \\
\text { affects culture, social life and the environment; d) From the scientific and regulatory point } \\
\text { of view, the presence of industrial ingredients and food additives can NOT be used as a } \\
\text { criterion for defining a food as unsuitable for consumption; e) From a practical point of } \\
\text { view, there is no way to establish the fact that a moderate use of sugar, salt and fats is } \\
\text { recommended for domestic culinary preparations, and that at the same time its use in the } \\
\text { industry generates products that should be avoided or contain such ingredients too much." } \\
\text { "The critical analysis of the characteristics specified for defining foods as being } \\
\text { "ultraprocessed" reveals that this concept is based on assumptions that contradict regulatory } \\
\text { agencies, that are not directly related to the content of products, and are found to be false } \\
\text { for most categories of industrialised products labeled "ultraprocessed foods"." } \\
\text { "a brief analysis of the products marketed in supermarkets can demonstrate that the concept } \\
\text { of "ultraprocessed food" cannot fulfill the purpose for which it was designed, i.e., to } \\
\text { identify food suitable for consumption, once a consumer attempts to select products by } \\
\text { comparing the products based on the characteristics pointed out by NOVA." } \\
\text { [Translated from Portuguese by first author] (Rego, Vialta, and Madi 2018) }\end{array}$ \\
\hline
\end{tabular}




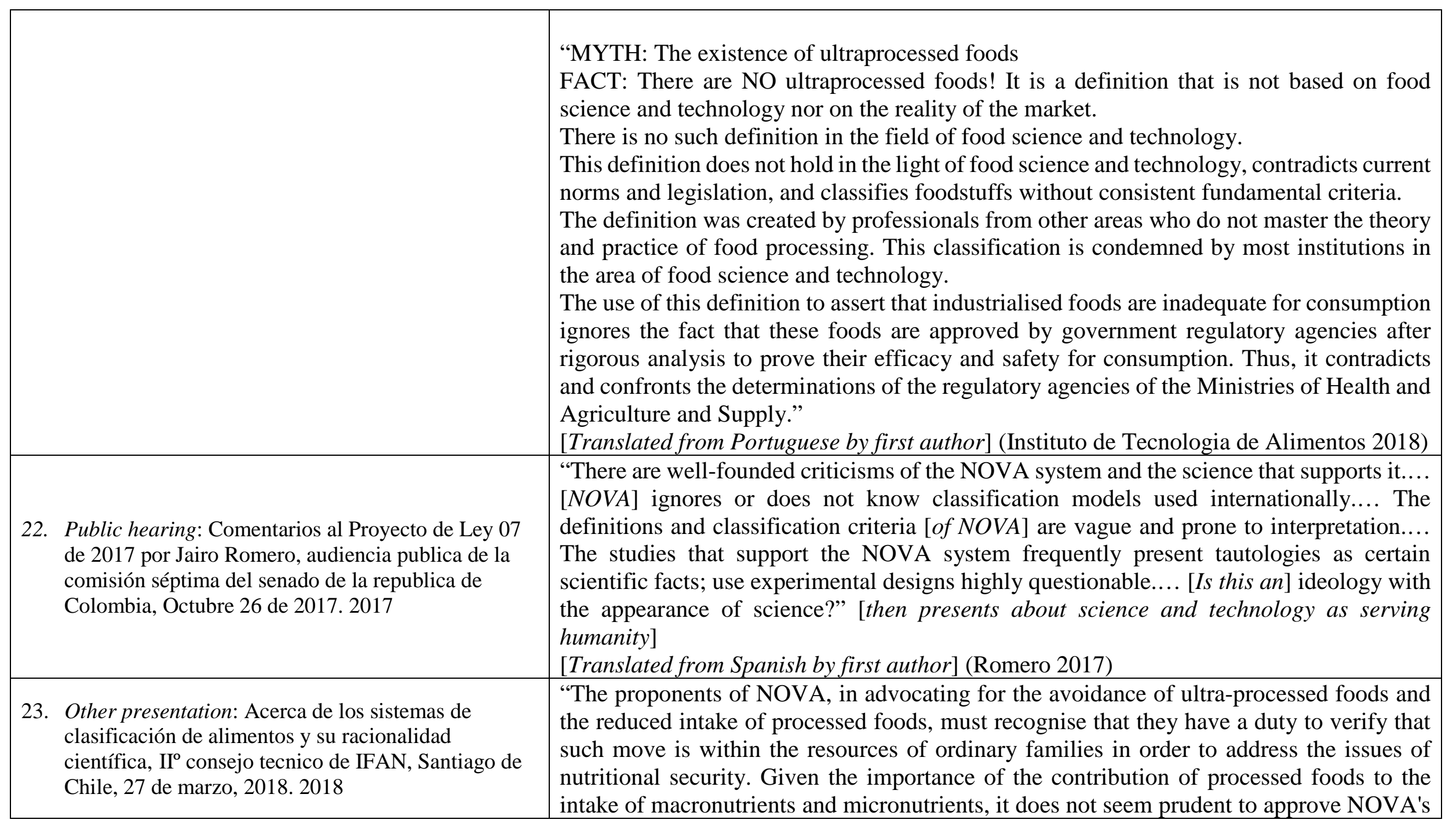




\begin{tabular}{|l|l|}
\hline & $\begin{array}{l}\text { recommendation to avoid the intake of ultra-processed foods and to minimise the intake of } \\
\text { processed foods. } \\
\text { To date, no data have been presented regarding the positive or negative results of that } \\
\text { strategy among free-living subjects and there are no data regarding the average consumer's } \\
\text { ability in terms of income, culinary skills, available culinary facilities and time or } \\
\text { availability of food to support the case that the abandonment of ultra-processed foods } \\
\text { would significantly alter the nutritional well-being. } \\
\text { Without these data, there may be some ethical issues that should be taken into account } \\
\text { before they occur.” [translated from Spanish by first author] (Moran 2017) }\end{array}$ \\
\hline $\begin{array}{l}\text { 24. Video: One Size Doesn't Fit All When it Comes To } \\
\text { Processed Foods } \\
\text { http://bcove.me/gzuw84ji }\end{array}$ & $\begin{array}{l}\text { Presentation of a different food classification. } \\
\text { Food that we purchase is safe to consume and have a good nutrition content. } \\
\text { (Eicher-Miller 2013) }\end{array}$ \\
$\begin{array}{l}\text { 25. Video: Processed Food Makes Our Lives Better } \\
\text { http://bcove.me/Onq5lbx2 }\end{array}$ & $\begin{array}{l}\text { The negative press about processed foods means that people don't understand that } \\
\text { processing can make foods healthier and that the food processing industry has made their } \\
\text { lives better. } \\
\text { (Decker 2013) }\end{array}$ \\
\hline $\begin{array}{l}\text { 26. Video: Everything is Processed } \\
\text { http://bcove.me/p3fyebvk }\end{array}$ & $\begin{array}{l}\text { Everything we eat is processed. We can't say that processing is bad because without } \\
\text { processing, we can't have the safe, the nutritious, the variety of foods that we have today; } \\
\text { and it has made our food a lot less expensive than what it used to be. } \\
\text { (Floros 2013) }\end{array}$ \\
\hline $\begin{array}{l}\text { 27. Video: Processed Foods Wonderful For Women } \\
\text { http://bcove.me/77r4zm4t }\end{array}$ & $\begin{array}{l}\text { Processed foods are wonderful for women as it allows them to go out, pursue their passion, } \\
\text { and come back to their homes and still be able to put a hot meal on the table, and ensure } \\
\text { that every member of their family gets what they want and what they like. } \\
\text { (Shelke 2013) }\end{array}$ \\
\hline
\end{tabular}


World Nutrition 2018;9(3):176-240

Appendix 3: Evidence for data included in Table 1 and in the results section of this manuscript

\begin{tabular}{|c|c|c|c|c|c|c|c|c|}
\hline $\begin{array}{l}\text { Name - } \\
\text { author }\end{array}$ & Institution & $\begin{array}{l}\text { Document } \\
\text { criticising } \\
\text { NOVA }\end{array}$ & $\begin{array}{l}\text { Where was } \\
\text { the } \\
\text { document } \\
\text { presented }\end{array}$ & $\begin{array}{l}\text { Document hosted by an } \\
\text { organisation that is } \\
\text { affiliated with the UPP } \\
\text { industry? }\end{array}$ & $\begin{array}{l}\text { Institution of the author } \\
\text { affiliated with the UPP } \\
\text { industry? }\end{array}$ & Declaration of interests & Funding aknowledgment & $\begin{array}{l}\text { Other links with the UPP } \\
\text { industry }\end{array}$ \\
\hline $\begin{array}{l}\text { Braesco } \\
\text { Véronique }\end{array}$ & $\begin{array}{l}\text { VAB } \\
\text { Nutrition, } \\
\text { France }\end{array}$ & $\begin{array}{l}\text { Séance } \\
\text { hebdomadaire } \\
\text { de } \\
\text { l'Académie } \\
\text { d'Agriculture } \\
\text { de France (6 } \\
\text { documents) } \\
\text { https://www.a } \\
\text { cademie- } \\
\text { agriculture.fr/ } \\
\text { actualites/aca } \\
\text { demie/seance/ } \\
\text { academie/des- } \\
\text { matieres- } \\
\text { premieres- } \\
\text { agricoles-aux- } \\
\text { aliments- } \\
\text { quel-impact- } \\
\text { des }\end{array}$ & $\begin{array}{l}\text { Académie } \\
\text { d'Agriculture }\end{array}$ & $\begin{array}{l}\text { The Academie is a partner of } \\
\text { most professional } \\
\text { organisations in the agro and } \\
\text { agrobusiness sector } \\
\text { https://www.academie- } \\
\text { agriculture.fr/academie/rayon } \\
\text { nement-partenariat/autres- } \\
\text { partenaires }\end{array}$ & & & & $\begin{array}{l}\text { Directrice du département } \\
\text { recherche nutrition du groupe } \\
\text { Danone (Danone Vitapole en } \\
\text { 2000), directrice du centre de } \\
\text { recherches en nutrition } \\
\text { humaine d'Auvergne et du } \\
\text { laboratoire INRA } \\
\text { "micronutriments et maladies } \\
\text { métaboliques" (2003), } \\
\text { directrice de VAB-nutrition, } \\
\text { une société de conseil et de } \\
\text { services en nutrition dédiée } \\
\text { aux acteurs du domaine } \\
\text { agro-alimentaire (depuis } \\
\text { 2007). } \\
\text { https://www.academie- } \\
\text { agriculture.fr/membres/annua } \\
\text { ire/veronique-braesco } \\
\text { Editorial Board of the Cahiers } \\
\text { de Nutrition et Diététique - } \\
\text { see info for "Cahiers de } \\
\text { Nutrition et Diététique" }\end{array}$ \\
\hline $\begin{array}{l}\text { Chardigny } \\
\text { Jean-Michel }\end{array}$ & $\begin{array}{l}\text { Institut } \\
\text { National de } \\
\text { Recherche } \\
\text { Agronomique } \\
\text { (INRA), } \\
\text { France }\end{array}$ & $\begin{array}{l}\text { Alimentation, } \\
\text { santé } \\
\text { publique, } \\
\text { étiquetage, où } \\
\text { va-t-on? } \\
\text { Cahiers de } \\
\text { Nutrition et } \\
\text { Diététique }\end{array}$ & $\begin{array}{l}\text { Cahiers de } \\
\text { Nutrition et } \\
\text { Diététique }\end{array}$ & $\begin{array}{l}\text { Yes, members of the editorial } \\
\text { board working for the food } \\
\text { industry (Nestlé and VAB } \\
\text { Nutrition) } \\
\text { https://www.journals.elsevier. } \\
\text { com/cahiers-de-nutrition-et- } \\
\text { de-dietetique/editorial-board }\end{array}$ & & & & $\begin{array}{l}\text { Participated in an ILSI } \\
\text { Europe event in 2012: } \\
\text { http://ilsi.eu/wp- } \\
\text { content/uploads/sites/3/2016/ } \\
\text { 06/p-MIN-WS-18jn12- } \\
\text { am.pdf } \\
\text { Conseil d'administration } \\
\text { FFAS: } \\
\text { http://alimentation- } \\
\text { sante.org/organisation/conseil } \\
\text {-dadministration/ }\end{array}$ \\
\hline $\begin{array}{l}\text { Clemens } \\
\text { Roger }\end{array}$ & $\begin{array}{l}\text { T. Horn La } \\
\text { Miranda, and } \\
\text { Southern } \\
\text { California }\end{array}$ & $\begin{array}{l}\text { Is Processed” } \\
\text { a Four-Letter } \\
\text { Word? The } \\
\text { Role of } \\
\text { Processed }\end{array}$ & $\begin{array}{l}\text { Advances in } \\
\text { Nutrition } \\
+\end{array}$ & $\begin{array}{l}\text { See Journal of the American } \\
\text { Society for Nutrition } \\
\text { Cereals } 17 \text { is organised by the } \\
\text { cereals industry }\end{array}$ & & $\begin{array}{l}\text { The ASN symposium was co- } \\
\text { sponsored by the Institute of } \\
\text { Food Technologists (IFT) } \\
\text { and the International Food } \\
\text { Information Council (IFIC). }\end{array}$ & & $\begin{array}{l}\text { http://www.polyscienceconsu } \\
\text { lting.com/roger-clemens.html } \\
\text { Scientific Advisor for Nestlé } \\
\text { USA for more than } 21 \text { years }\end{array}$ \\
\hline
\end{tabular}


World Nutrition 2018;9(3):176-240

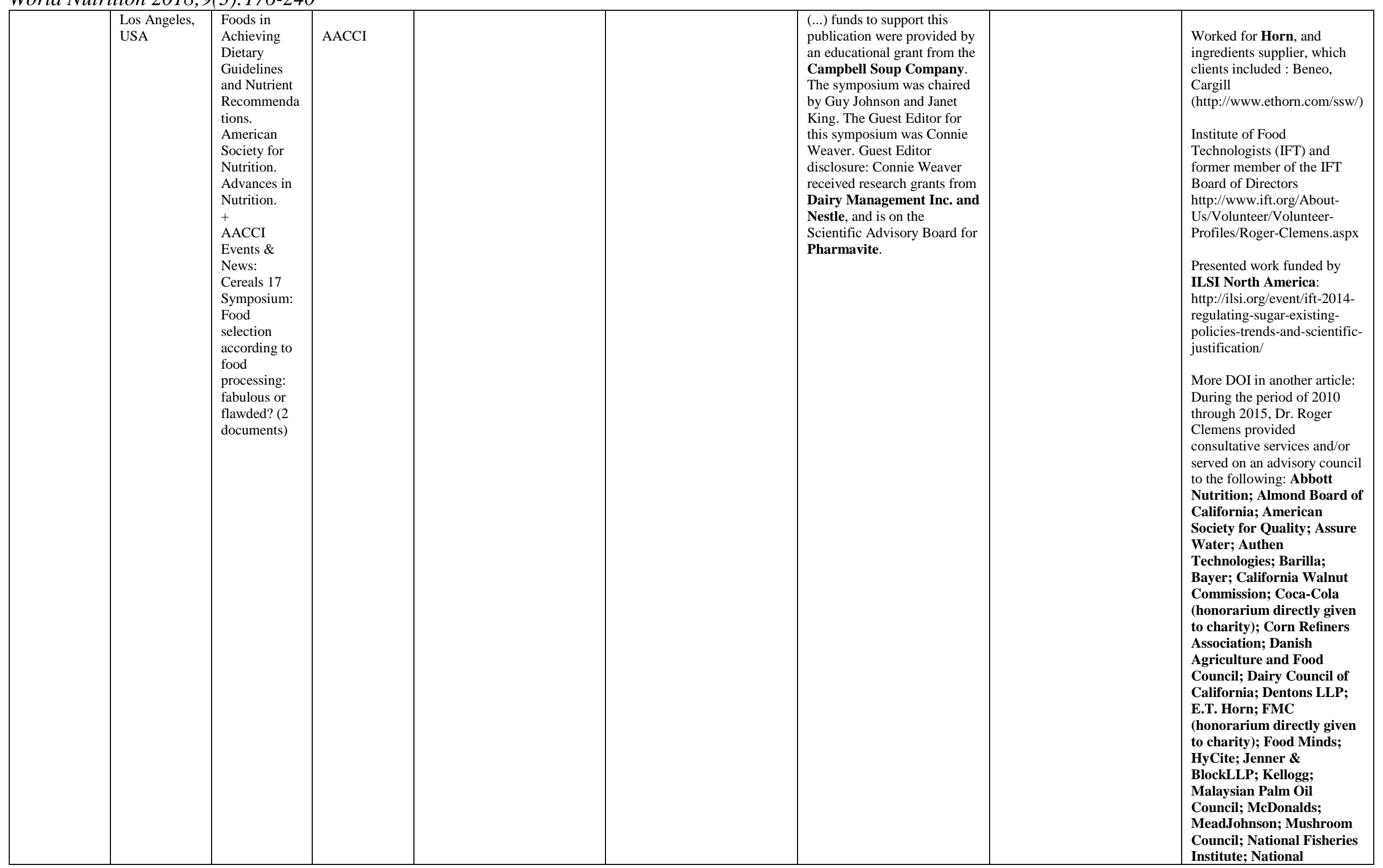




\begin{tabular}{|c|c|c|c|c|c|}
\hline & & & & & $\begin{array}{l}\text { Restaurant Association; } \\
\text { Nestle SA; Petcurean; } \\
\text { Quaker Oats;Schwann } \\
\text { Foods; Senomyx } \\
\text { (honorarium directly given } \\
\text { to charity);Spherix; U.S. } \\
\text { Dept. of Agriculture; } \\
\text { Whitewave and Yakult. } \\
\text { https:///onlinelibrary.wiley.co } \\
\text { m/doi/epdff/10.1111/1541- } \\
\text { 4337.12194 }\end{array}$ \\
\hline $\begin{array}{l}\text { Darmon } \\
\text { Nicole }\end{array}$ & $\begin{array}{l}\text { Univ Aix- } \\
\text { Marseille 1, } \\
\text { Univ Aix- } \\
\text { Marseille 2, } \\
\text { France }\end{array}$ & $\begin{array}{l}\text { Nutrient } \\
\text { profiling: The } \\
\text { good, the bad, } \\
\text { and the ultra- } \\
\text { processed. } \\
\text { Public Health } \\
\text { Nutrition. }\end{array}$ & $\begin{array}{l}\text { Public Health } \\
\text { Nutrition }\end{array}$ & & 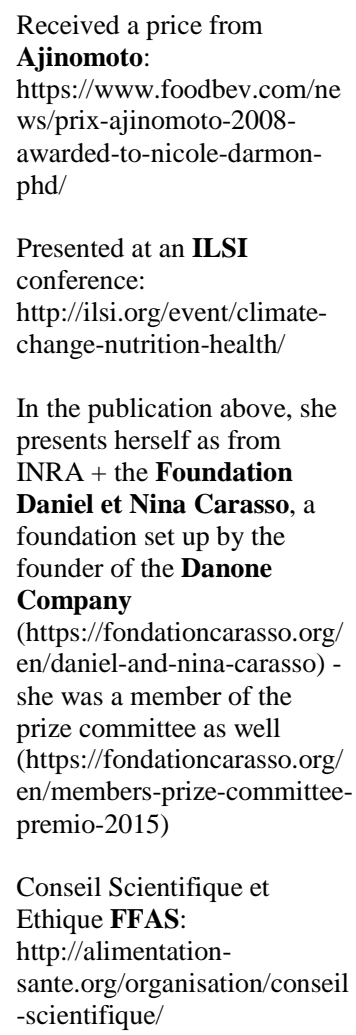 \\
\hline Decker Eric & $\begin{array}{l}\text { University of } \\
\text { Massachusett } \\
\text { s, USA }\end{array}$ & $\begin{array}{l}\text { Video: } \\
\text { Processed } \\
\text { Food Makes } \\
\text { Our Lives } \\
\text { Better }\end{array}$ & $\begin{array}{l}\text { Institute of } \\
\text { Food } \\
\text { Technologists }\end{array}$ & See IFT & $\begin{array}{l}\text { ILSI North America award } \\
\text { in } 2017 \\
\text { http://ilsina.org/about- } \\
\text { us/award-programs/ } \\
+\end{array}$ \\
\hline
\end{tabular}


World Nutrition 2018;9(3):176-240

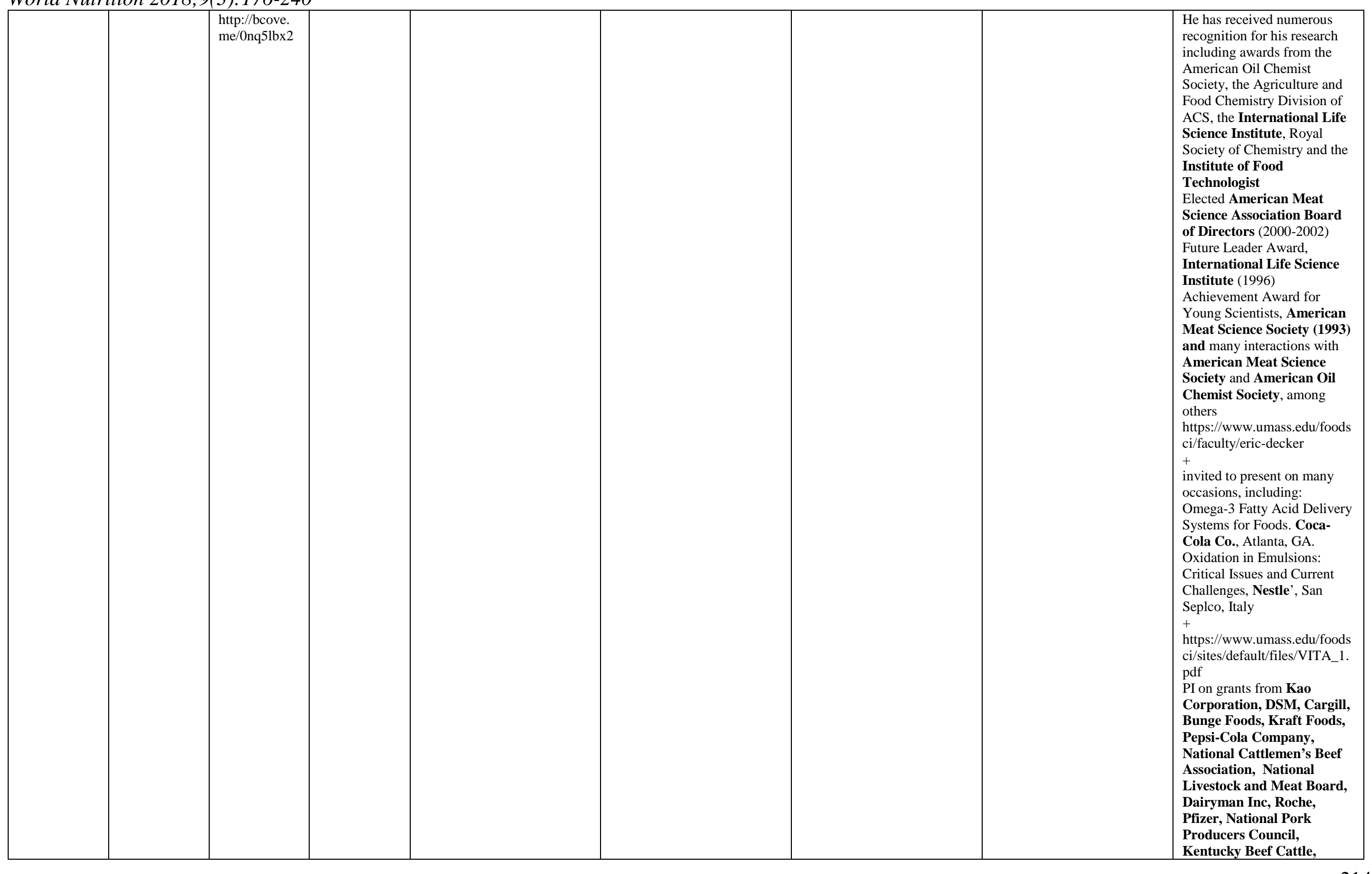




\begin{tabular}{|c|c|c|c|c|c|c|}
\hline & & & & & & $\begin{array}{l}\text { National Dairy Council } \\
\text { Association, National Dairy } \\
\text { Research and Promotion } \\
\text { Board + many other as a co- } \\
\text { I }\end{array}$ \\
\hline $\begin{array}{l}\text { Dupont } \\
\text { Didier }\end{array}$ & INRA, France & $\begin{array}{l}\text { Séance } \\
\text { hebdomadaire } \\
\text { de } \\
\text { l'Académie } \\
\text { d'Agriculture } \\
\text { de France (6 } \\
\text { documents) } \\
\text { https://www.a } \\
\text { cademie- } \\
\text { agriculture.fr/ } \\
\text { actualites/aca } \\
\text { demie/seance/ } \\
\text { academie/des- } \\
\text { matieres- } \\
\text { premieres- } \\
\text { agricoles-aux- } \\
\text { aliments- } \\
\text { quel-impact- } \\
\text { des }\end{array}$ & $\begin{array}{l}\text { Académie } \\
\text { d'Agriculture }\end{array}$ & $\begin{array}{l}\text { The Academie is a partner of } \\
\text { most prof organisations in the } \\
\text { agro and agrobusiness sector } \\
\text { https://www.academie- } \\
\text { agriculture.fr/academie/rayon } \\
\text { nement-partenariat/autres- } \\
\text { partenaires }\end{array}$ & & \\
\hline $\begin{array}{l}\text { Dwyer } \\
\text { Johanna }\end{array}$ & $\begin{array}{l}\text { Tufts } \\
\text { University , } \\
\text { and Office of } \\
\text { Dietary } \\
\text { Supplements, } \\
\text { National } \\
\text { Institutes of } \\
\text { Health, USA }\end{array}$ & $\begin{array}{l}\text { Processed } \\
\text { foods: } \\
\text { contributions } \\
\text { to nutrition. } \\
\text { American } \\
\text { Journal of } \\
\text { Clinical } \\
\text { Nutrition. } \\
\text { + Is } \\
\text { "Processed" a } \\
\text { Four-Letter } \\
\text { Word? The } \\
\text { Role of } \\
\text { Processed } \\
\text { Foods in } \\
\text { Achieving } \\
\text { Dietary } \\
\text { Guidelines } \\
\text { and Nutrient } \\
\text { Recommenda } \\
\text { tions. } \\
\text { American } \\
\text { Society for } \\
\text { Nutrition. }\end{array}$ & $\begin{array}{l}\text { American } \\
\text { Journal of } \\
\text { Clinical } \\
\text { Nutrition+Am } \\
\text { erican Society } \\
\text { fo Nutrition }\end{array}$ & $\begin{array}{l}\text { See Journal of the American } \\
\text { Society for Nutrition }\end{array}$ & $\begin{array}{l}\text { J Dwyer, serves as an unpaid } \\
\text { board member for the } \\
\text { International Life Sciences } \\
\text { Institute of North America; } \\
\text { serves on scientific advisory } \\
\text { boards for ConAgra Foods } \\
\text { Inc, McCormick Inc, Bay } \\
\text { State Milling, and } \\
\text { Nestle;performed speaking } \\
\text { engagements for Ocean } \\
\text { Spray and the Alliance for } \\
\text { Potato Research and } \\
\text { Education; and owns stock } \\
\text { in ConAgra Foods Inc, } \\
\text { McCormick Inc, and } \\
\text { Hershey.The ASN } \\
\text { symposium was co-sponsored } \\
\text { by the Institute of Food } \\
\text { Technologists (IFT) and the } \\
\text { International Food } \\
\text { Information Council (IFIC). } \\
\text { (...) funds to support this } \\
\text { publication were provided by } \\
\text { an educational grant from the } \\
\text { Campbell Soup Company. }\end{array}$ & \\
\hline
\end{tabular}


World Nutrition 2018;9(3):176-240

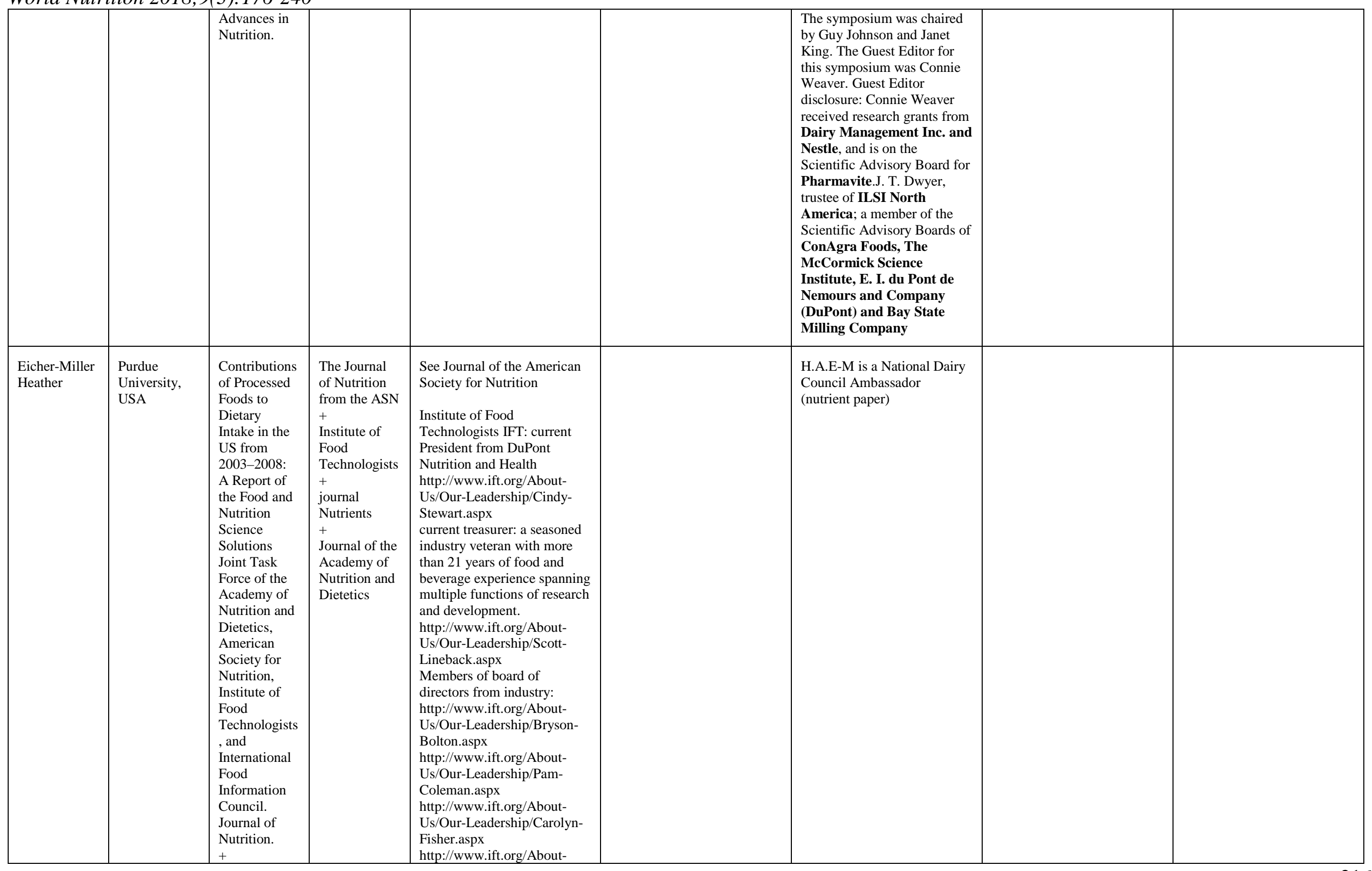


World Nutrition 2018;9(3):176-240

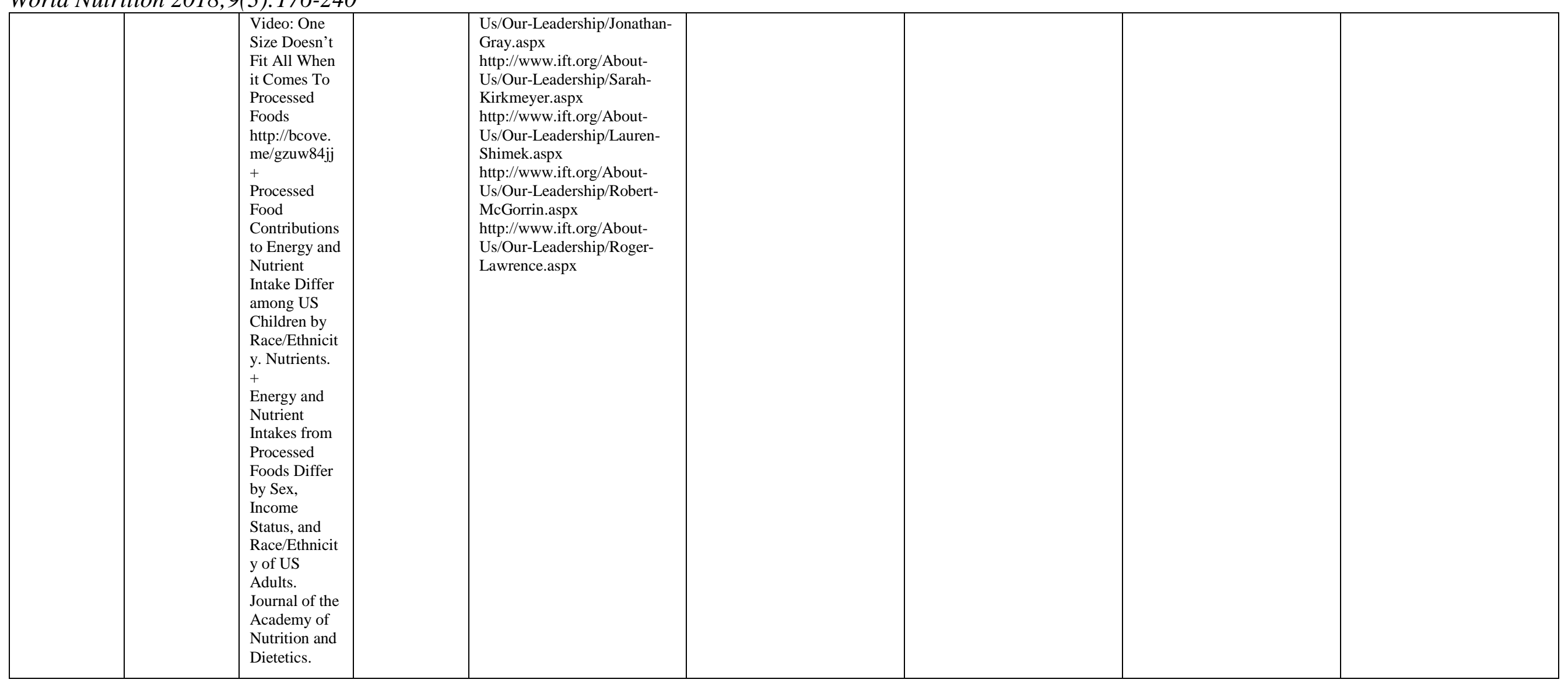


World Nutrition 2018;9(3):176-240

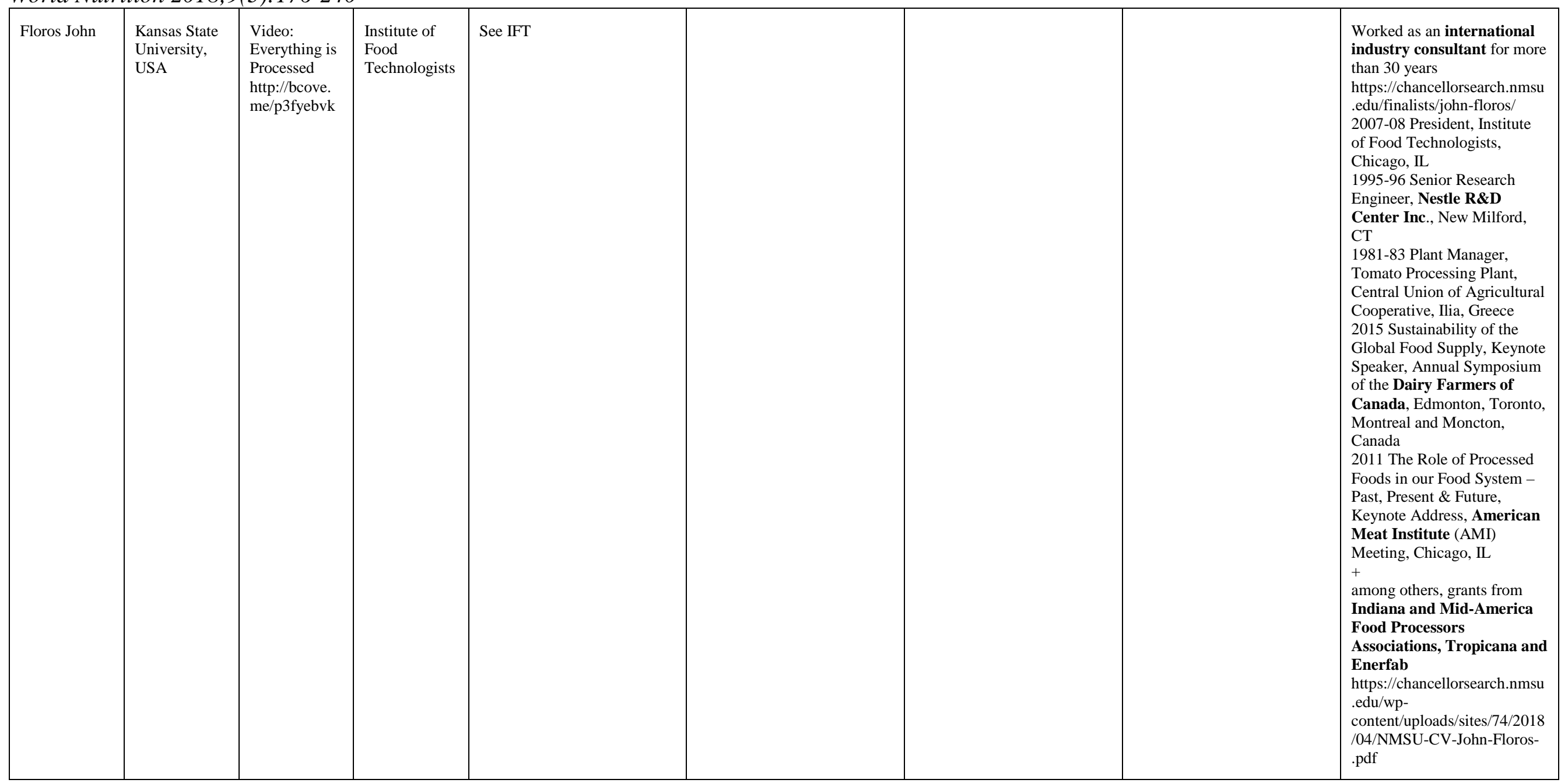


World Nutrition 2018;9(3):176-240

\begin{tabular}{|c|c|c|c|c|c|c|}
\hline Forde Ciaran & $\begin{array}{l}\text { Singapore } \\
\text { Institute for } \\
\text { Clinical } \\
\text { Sciences | } \\
\text { SICS · } \\
\text { Clinical } \\
\text { Nutrition } \\
\text { Research } \\
\text { Center, } \\
\text { Singapour }\end{array}$ & $\begin{array}{l}\text { Ultra- } \\
\text { processed } \\
\text { foods in } \\
\text { human health: } \\
\text { a critical } \\
\text { appraisal. } \\
\text { American } \\
\text { Journal of } \\
\text { Clinical } \\
\text { Nutrition. } \\
\text { (and } \\
\text { corrigendum) }\end{array}$ & $\begin{array}{l}\text { American } \\
\text { Journal of } \\
\text { Clinical } \\
\text { Nutrition }\end{array}$ & $\begin{array}{l}\text { Journal of the American } \\
\text { Society for Nutrition } \\
\text { List of partners from the } \\
\text { industry } \\
\text { https://nutrition.org/sustainin } \\
\text { g-partners/ } \\
\text { Abbott Nutrition, Almond } \\
\text { Board of California, Bayer } \\
\text { HealthCare, Biofortis Clinical } \\
\text { Research, California Walnut } \\
\text { Commission, Cargill, Inc., } \\
\text { Corn Refiners Association, } \\
\text { Council for Responsible } \\
\text { Nutrition, Dairy Research } \\
\text { Institute, DSM Nutritional } \\
\text { Products, LLC, Dupont } \\
\text { Nutrition \& Health, Egg } \\
\text { Nutrition Center, General } \\
\text { Mills Bell Institute of Health } \\
\text { and Nutrition, } \\
\text { Herbalife/Herbalife Nutrition } \\
\text { Institute, International Bottled } \\
\text { Water Foundation, Kellogg } \\
\text { Company, Kyowa Hakko } \\
\text { U.S.A., Inc., Mars Inc., } \\
\text { McCormick Science Institute, } \\
\text { Mondelez International } \\
\text { Technical Center, Monsanto } \\
\text { Company, National } \\
\text { Cattlemenn's Beef } \\
\text { Association, a contractor to } \\
\text { The Beef Checkoff, Nestle } \\
\text { Nutrition, Medical Affairs, } \\
\text { PepsiCo, Pfizer, Inc., } \\
\text { Pharmavite LLC, Tate \& } \\
\text { Lyle, The a2 Milk Company } \\
\text { The Coca Cola Company, } \\
\text { The Dannon Company, Inc., } \\
\text { The Sugar Association, } \\
\text { Unilever } \\
\text { ASN Foundation's 2018 } \\
\text { scholarships } \\
\text { https://nutrition.org/about- } \\
\text { asn/awards/ } \\
\text { The Gerber Foundation } \\
\text { Predoctoral Fellowship } \\
\text { The Pfizer Predoctoral } \\
\text { Fellowship } \\
\text { The Mars, Inc. Predoctoral } \\
\text { Fellowship }\end{array}$ & $\begin{array}{l}\text { Until October 31, 2014, } \\
\text { employee of the Nestle } \\
\text { Research Center } \\
\text { He has received travel } \\
\text { reimbursement from Kerry } \\
\text { Taste and Nutrition } \\
\text { Some of his research on child } \\
\text { eating behavior is partially } \\
\text { co-funded by the Nestle } \\
\text { Research Center }\end{array}$ & $\begin{array}{l}\text { Sensory Ingestive Behaviour } \\
\text { Team - Clinical Nutrition } \\
\text { Research Centre Singapore } \\
\text { Institute for Clinical Sciences } \\
\text { Dept. Physiology, NUS - } \\
\text { Acknowledgements: } \\
\text { Research Grant Support from } \\
\text { the Nestle Research Centre- } \\
\text { Epigen Collaboration fund; } \\
\text { (G00067; BMSI/15-300004- } \\
\text { SICS) awarded to Assoc. } \\
\text { Prof. C.G. Forde. } \\
\text { Presented at in ILSI SEA } \\
\text { publication } \\
\text { http://ilsisea-region.org/wp- } \\
\text { content/uploads/sites/21/2016 } \\
\text { /12/02-Ciaran-Forde.pdf }\end{array}$ \\
\hline
\end{tabular}


World Nutrition 2018;9(3):176-240

\begin{tabular}{|c|c|c|c|c|c|c|}
\hline $\begin{array}{l}\text { Franciscato } \\
\text { Cozzolino } \\
\text { Silvia Maria }\end{array}$ & $\begin{array}{l}\text { University of } \\
\text { São Paulo, } \\
\text { Brazil }\end{array}$ & $\begin{array}{l}\text { Comparison } \\
\text { of Child } \\
\text { Lunch Meals } \\
\text { in Brazil. } \\
\text { Food and } \\
\text { Nutrition } \\
\text { Sciences. }\end{array}$ & $\begin{array}{l}\text { Food and } \\
\text { Nutrition } \\
\text { Sciences }\end{array}$ & & $\begin{array}{l}\text { The authors acknowledge } \\
\text { Equilibrium Consultancy } \\
\text { which led this study. Funding } \\
\text { by McDonald's Corporation } \\
\text { for the project was primarily } \\
\text { to Equilibrium. (...) CSMF } \\
\text { advises McDonald's on } \\
\text { nutrition issues. }\end{array}$ & $\begin{array}{l}\text { Wrote reports for ILSI Brasil } \\
\text { in 2017 } \\
\text { http://ilsibrasil.org/wp- } \\
\text { content/uploads/sites/9/2017/ } \\
\text { 07/Fasc\%C3\%ADculo- } \\
\text { RECOMENDACOES-DE- } \\
\text { NUTRIENTES.pdf } \\
\text { http://ilsi.org/brasil/wp- } \\
\text { content/uploads/sites/9/2016/ } \\
\text { 05/08-Sele\%CC\%82nio.pdf } \\
\text { Funded and past president of } \\
\text { SBAN - many links with the } \\
\text { food industry: Nestlé, } \\
\text { Cargill, Danone, Gatorade, } \\
\text { ABIA, Coca Cola, Unilever, } \\
\text { Herbalife, Performance } \\
\text { Nutrition } \\
\text { http://www.sban.org.br/congr } \\
\text { esso2017/convidados- } \\
\text { nacionais/ } \\
\text { http://www.sban.org.br/parcei } \\
\text { ros/parceiros.php } \\
\text { http://www.sban.org.br/socie } \\
\text { dade/historico.php }\end{array}$ \\
\hline $\begin{array}{l}\text { Freedman } \\
\text { Marjorie }\end{array}$ & $\begin{array}{l}\text { San José State } \\
\text { University, } \\
\text { USA }\end{array}$ & $\begin{array}{l}\text { Publication in } \\
\text { scientific } \\
\text { journal/event: } \\
\text { Is } \\
\text { "Processed" a } \\
\text { Four-Letter } \\
\text { Word? The } \\
\text { Role of } \\
\text { Processed } \\
\text { Foods in } \\
\text { Achieving } \\
\text { Dietary } \\
\text { Guidelines } \\
\text { and Nutrient } \\
\text { Recommenda } \\
\text { tions. } \\
\text { American } \\
\text { Society for } \\
\text { Nutrition. } \\
\text { Advances in } \\
\text { Nutrition. }\end{array}$ & $\begin{array}{l}\text { Advances in } \\
\text { Nutrition }\end{array}$ & $\begin{array}{l}\text { See Journal of the American } \\
\text { Society for Nutrition }\end{array}$ & $\begin{array}{l}\text { The ASN symposium was co- } \\
\text { sponsored by the Institute of } \\
\text { Food Technologists (IFT) } \\
\text { and the International Food } \\
\text { Information Council (IFIC). } \\
\text { (...) funds to support this } \\
\text { publication were provided by } \\
\text { an educational grant from the } \\
\text { Campbell Soup Company. } \\
\text { The symposium was chaired } \\
\text { by Guy Johnson and Janet } \\
\text { King. The Guest Editor for } \\
\text { this symposium was Connie } \\
\text { Weaver. Guest Editor } \\
\text { disclosure: Connie Weaver } \\
\text { received research grants from } \\
\text { Dairy Management Inc. and } \\
\text { Nestle, and is on the } \\
\text { Scientific Advisory Board for } \\
\text { Pharmavite. }\end{array}$ & $\begin{array}{l}\text { As Manager, Scientific } \\
\text { Affairs, for The NutraSweet } \\
\text { Company, Freedman } \\
\text { traveled throughout the US } \\
\text { and abroad educating health } \\
\text { care professionals about the } \\
\text { safety and benefits of the } \\
\text { high-intensity sweetener } \\
\text { NutraSweet (aspartame). (...). } \\
\text { As a nutrition consultant, } \\
\text { Freedman provided expertise } \\
\text { to Shape Up America!, The } \\
\text { Kellogg Company, The } \\
\text { McDonalds Corp., Murdoch } \\
\text { books, and the USDA. } \\
\text { http://www.sjsu.edu/people/m } \\
\text { arjorie.freedman/ }\end{array}$ \\
\hline
\end{tabular}


World Nutrition 2018;9(3):176-240

\begin{tabular}{|c|c|c|c|c|c|c|c|}
\hline $\begin{array}{l}\text { Fulgoni III } \\
\text { Victor }\end{array}$ & $\begin{array}{l}\text { Nutrition } \\
\text { Impact, LLC } \\
\text { Battle Creek, } \\
\text { USA }\end{array}$ & $\begin{array}{l}\text { Processed } \\
\text { foods: } \\
\text { contributions } \\
\text { to nutrition. } \\
\text { American } \\
\text { Journal of } \\
\text { Clinical } \\
\text { Nutrition } \\
\text { +Is } \\
\text { "Processed" a } \\
\text { Four-Letter } \\
\text { Word? The } \\
\text { Role of } \\
\text { Processed } \\
\text { Foods in } \\
\text { Achieving } \\
\text { Dietary } \\
\text { Guidelines } \\
\text { and Nutrient } \\
\text { Recommenda } \\
\text { tions. } \\
\text { American } \\
\text { Society for } \\
\text { Nutrition. } \\
\text { Advances in } \\
\text { Nutrition. } \\
\text { +Contribution } \\
\text { s of Processed } \\
\text { Foods to } \\
\text { Dietary } \\
\text { Intake in the } \\
\text { US from } \\
\text { 2003-2008: } \\
\text { A Report of } \\
\text { the Food and } \\
\text { Nutrition } \\
\text { Science } \\
\text { Solutions } \\
\text { Joint Task } \\
\text { Force of the } \\
\text { Academy of } \\
\text { Nutrition and } \\
\text { Dietetics, } \\
\text { American } \\
\text { Society for } \\
\text { Nutrition, } \\
\text { Institute of } \\
\text { Food } \\
\text { Technologists } \\
\text {, and }\end{array}$ & $\begin{array}{l}\text { American } \\
\text { Journal of } \\
\text { Clinical } \\
\text { Nutrition } \\
\text { +Advances in } \\
\text { Nutrition } \\
\text { +The Journal } \\
\text { of Nutrition } \\
\text { from the ASN } \\
\text { +journal } \\
\text { Nutrients } \\
\text { +Journal of } \\
\text { the Academy } \\
\text { of Nutrition } \\
\text { and Dietetics }\end{array}$ & $\begin{array}{l}\text { See Journal of the American } \\
\text { Society for Nutrition }\end{array}$ & $\begin{array}{l}\text { https://www.sourcewatch.org/ } \\
\text { index.php/Nutrition_Impact,_- } \\
\text { LLCNutrition Impact, LLC } \\
\text { helps companies market } \\
\text { their food products by } \\
\text { promising drug-like } \\
\text { benefits. }\end{array}$ & $\begin{array}{l}\text { VL Fulgoni III, performs } \\
\text { consulting and database } \\
\text { analyses for various food } \\
\text { and beverage companies } \\
\text { and related entitiesThe ASN } \\
\text { symposium was co-sponsored } \\
\text { by the Institute of Food } \\
\text { Technologists (IFT) and the } \\
\text { International Food } \\
\text { Information Council (IFIC). } \\
\text { (...) funds to support this } \\
\text { publication were provided by } \\
\text { an educational grant from the } \\
\text { Campbell Soup Company. } \\
\text { The symposium was chaired } \\
\text { by Guy Johnson and Janet } \\
\text { King. The Guest Editor for } \\
\text { this symposium was Connie } \\
\text { Weaver. Guest Editor } \\
\text { disclosure: Connie Weaver } \\
\text { received research grants from } \\
\text { Dairy Management Inc. and } \\
\text { Nestle, and is on the } \\
\text { Scientific Advisory Board for } \\
\text { Pharmavite.Senior Vice } \\
\text { President of Nutrition Impact, } \\
\text { LLC performs consulting } \\
\text { services and database } \\
\text { analyses for various food } \\
\text { and beverage companies } \\
\text { and related entities (nutrient } \\
\text { paper) }\end{array}$ & $\begin{array}{l}\text { https://www.sourcewatch.org/ } \\
\text { index.php/Nutrition_Impact,_ } \\
\text { LLCformer Kellogg Vice } \\
\text { President Victor L. Fugoni } \\
\text { IIISeveral publications } \\
\text { funded by the industry: } \\
\text { https://nutritionj.biomedcentr } \\
\text { al.com/articles/10.1186/s1293 } \\
\text { 7-015-0057-5: The study and } \\
\text { the writing of the manuscript } \\
\text { were supported by Dairy } \\
\text { Management Inc. } \\
\text { https://nutritionj.biomedcentr } \\
\text { al.com/articles/10.1186/s1293 } \\
\text { 7-015-0118-9: The present } \\
\text { study was funded by North } \\
\text { American Meat Institute. } \\
\text { https://www.researchgate.net/ } \\
\text { publication/326006345_The_- } \\
\text { Pattern_of_Complementary_ } \\
\text { Foods_in_American_Infants_ } \\
\text { and_Children_Aged_0- } \\
\text { 5_Years_Old-A_Cross- } \\
\text { Sectional_Analysis_of_Data_ } \\
\text { from_the_NHANES_2011-- } \\
\text { 2014: This research was } \\
\text { funded by National Dairy } \\
\text { Council/Dairy Management } \\
\text { Inc } \\
\text { https://www.researchgate.net/ } \\
\text { publication/322562476_Sour } \\
\text { ces_of_Added_Sugars_in_YYo } \\
\text { ung_Children_Adolescents_a } \\
\text { nd_Adults_with_Low_and_H } \\
\text { igh_Intakes_of_Added_Sugar } \\
\text { s: Nutrition Impact LLC } \\
\text { (Battle Creek, MI, USA) } \\
\text { received financial support } \\
\text { from the Sugar Association } \\
\text { for the research presented } \\
\text { here } \\
\text { https://www.ncbi.nlm.nih.gov } \\
\text { /pmc/articles/PMC5986414/: } \\
\text { The present research was } \\
\text { funded and supported by the } \\
\text { Grain Foods Foundation in } \\
\text { Washington, D.C. } \\
\text { https://www.researchgate.net/ } \\
\text { publication/313871451_Sever } \\
\text { al_grain_dietary_patterns_are } \\
\text { _associated_with_better_diet }\end{array}$ \\
\hline
\end{tabular}




\begin{tabular}{|c|c|c|c|c|c|c|}
\hline & & $\begin{array}{l}\text { International } \\
\text { Food } \\
\text { Information } \\
\text { Council. } \\
\text { Journal of } \\
\text { Nutrition. } \\
\text { +Processed } \\
\text { Food } \\
\text { Contributions } \\
\text { to Energy and } \\
\text { Nutrient } \\
\text { Intake Differ } \\
\text { among US } \\
\text { Children by } \\
\text { Race/Ethnicit } \\
\text { y. Nutrients. } \\
\text { +Energy and } \\
\text { Nutrient } \\
\text { Intakes from } \\
\text { Processed } \\
\text { Foods Differ } \\
\text { by Sex, } \\
\text { Income } \\
\text { Status, and } \\
\text { Race/Ethnicit } \\
\text { y of US } \\
\text { Adults. } \\
\text { Journal of the } \\
\text { Academy of } \\
\text { Nutrition and } \\
\text { Dietetics. }\end{array}$ & & & & $\begin{array}{l}\text {-quality_and_improved_short } \\
\text { fall_nutrient_intakes_in_US_ } \\
\text { children_and_adolescents_a_ } \\
\text { study_focusing_on_the_2015 } \\
\text { - } \\
\text { 2020_Dietary_Guidelines_for } \\
\text {-A: This project has been } \\
\text { funded by the Grain Foods } \\
\text { Foundation. }\end{array}$ \\
\hline $\begin{array}{l}\text { Gibney } \\
\text { Michael }\end{array}$ & $\begin{array}{l}\text { University } \\
\text { College } \\
\text { Dublin, } \\
\text { Ireland }\end{array}$ & $\begin{array}{l}\text { Ultra- } \\
\text { processed } \\
\text { foods in } \\
\text { human health: } \\
\text { a critical } \\
\text { appraisal. } \\
\text { American } \\
\text { Journal of } \\
\text { Clinical } \\
\text { Nutrition. } \\
\text { (and } \\
\text { corrigendum) } \\
+ \\
\text { Belgian } \\
\text { Nutrition } \\
\text { Society, Eight } \\
\text { annual } \\
\text { meeting, May } \\
\text { 4th, 2018: } \\
\end{array}$ & $\begin{array}{l}\text { American } \\
\text { Journal of } \\
\text { Clinical } \\
\text { Nutrition } \\
+ \\
\text { Belgian } \\
\text { Nutrition } \\
\text { Society } \\
+ \\
+ \\
\text { Current } \\
\text { Development } \\
\text { s in Nutrition }\end{array}$ & $\begin{array}{l}\text { See Journals of the American } \\
\text { Society for Nutrition } \\
\text { Sessions of the BNS } \\
\text { sponsored by Yakult, } \\
\text { Fédération de I'Industrie } \\
\text { Alimentaire (FEVIA) and } \\
\text { Beneo Institute }\end{array}$ & $\begin{array}{l}\text { MJG serves on scientific } \\
\text { committees for Nestle and } \\
\text { Cereal Partners Worldwide } \\
\text { The author does ad hoc } \\
\text { consultancy work with } \\
\text { Nestlé, chairs the } \\
\text { International Breakfast } \\
\text { research Consortium funded } \\
\text { by Cereal Partners } \\
\text { Worldwide, leads a project } \\
\text { on the developing food } \\
\text { serving sizes for use in the } \\
\text { EU funded by Mondelez, } \\
\text { PepsiCo, Unilever, Nestle } \\
\text { and Coca Cola and is on the } \\
\text { board of director s of ILSI } \\
\text { Europe. }\end{array}$ & $\begin{array}{l}\text { Members of the Board of } \\
\text { Directors (as of June 2018) } \\
\text { ILSI Europe } \\
\text { http://ilsi.eu/about-us/ } \\
\text { Published several articles that } \\
\text { were commissioned by ILSI } \\
\text { Europe: } \\
\text { https://link.springer.com/artic } \\
\text { le/10.1007/s00394-007-2004- } \\
\text { 5: This publication was } \\
\text { coordinated by Carina } \\
\text { Madsen, Scientific Project } \\
\text { Manager at ILSI Europe. This } \\
\text { work was commissioned by } \\
\text { the Functional Foods Task } \\
\text { Force of the European branch } \\
\text { of the International Life } \\
\text { Sciences Institute (ILSI }\end{array}$ \\
\hline
\end{tabular}


World Nutrition 2018;9(3):176-240

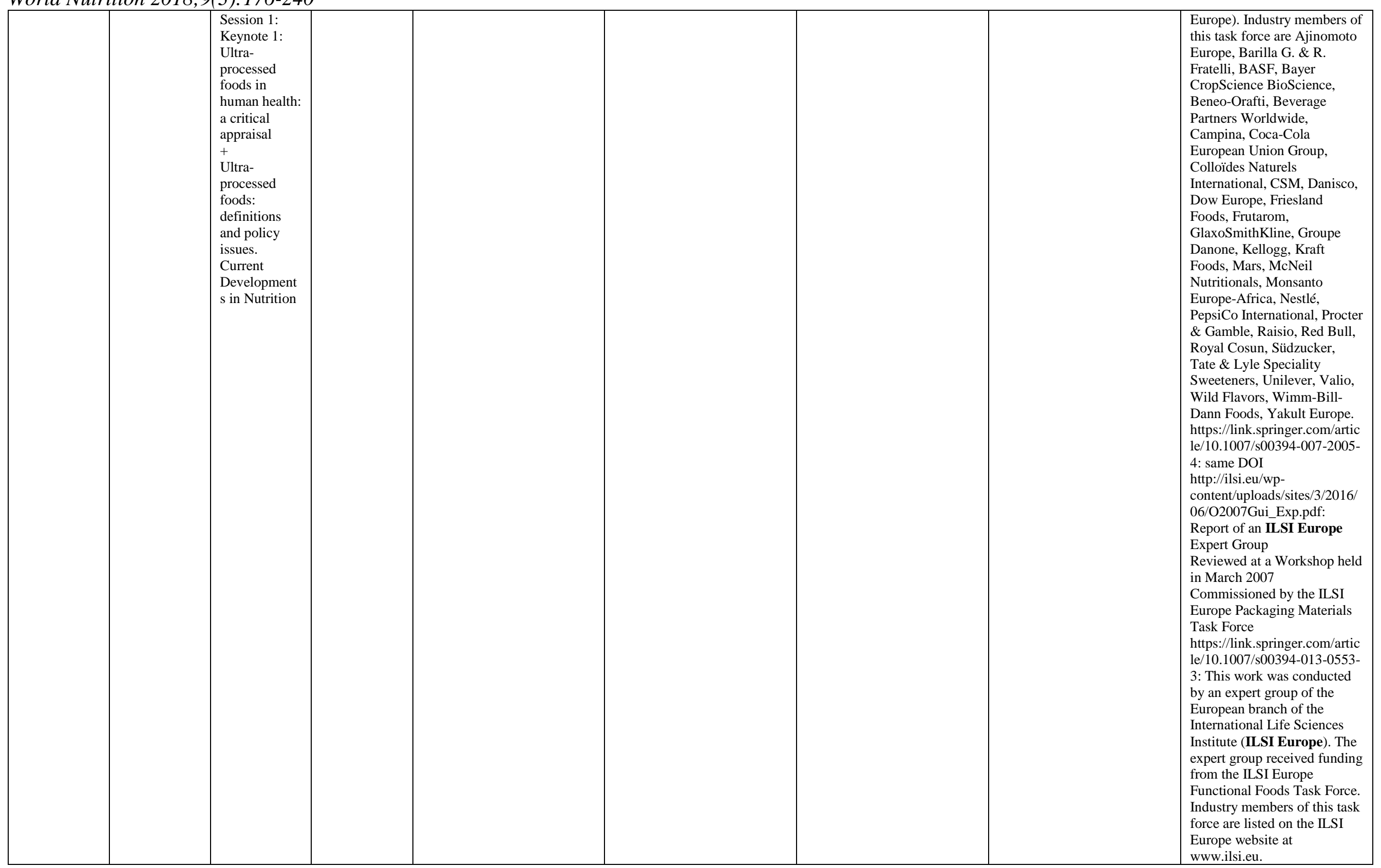


World Nutrition 2018;9(3):176-240

\begin{tabular}{|c|c|c|c|c|c|c|c|}
\hline & & & & & & & $\begin{array}{l}\text { Participated in events hosted } \\
\text { by ILSI Europe: } \\
\text { http://ilsi.eu/event/marker- } \\
\text { initiative-in-nutritional- } \\
\text { research-workshop/ }\end{array}$ \\
\hline $\begin{array}{l}\text { Gibney } \\
\text { Eileen }\end{array}$ & $\begin{array}{l}\text { University } \\
\text { College } \\
\text { Dublin, } \\
\text { Ireland }\end{array}$ & $\begin{array}{l}\text { Ultra- } \\
\text { processed } \\
\text { foods in } \\
\text { human health: } \\
\text { a critical } \\
\text { appraisal. } \\
\text { American } \\
\text { Journal of } \\
\text { Clinical } \\
\text { Nutrition. } \\
\text { (and } \\
\text { corrigendum) }\end{array}$ & $\begin{array}{l}\text { American } \\
\text { Journal of } \\
\text { Clinical } \\
\text { Nutrition }\end{array}$ & $\begin{array}{l}\text { See Journal of the American } \\
\text { Society for Nutrition }\end{array}$ & & & $\begin{array}{l}\text { http://www.ucd.ie/research/pe } \\
\text { ople/agriculturefoodscience/d } \\
\text { reileengibney/ } \\
\text { research sponsored by } \\
\text { Glanbia Ingredients Ireland } \\
\text { Ltd and Glanbia } \\
\text { Nutritionals (Research) Ltd. } \\
\text { Consultancy for Drury } \\
\text { Communications, whose } \\
\text { clients include Mc Donald's } \\
\text { and Love Irish Food } \\
\text { (https://www.drurypn.ie/clien } \\
\text { ts/) } \\
\text { and for Wilson Hartnell PR, } \\
\text { whose projects included food } \\
\text { products } \\
\text { (https://www.wilsonhartnell.i } \\
\text { e/project/set-siucra-summer/) }\end{array}$ \\
\hline $\begin{array}{l}\text { Guy-Grand } \\
\text { Bernard }\end{array}$ & $\begin{array}{l}\text { Worked in the } \\
\text { hospital } \\
\text { l'Hôtel-Dieu } \\
\text { (Paris), } \\
\text { France and } \\
\text { currently } \\
\text { president of } \\
\text { the editorial } \\
\text { committee of } \\
\text { the journal } \\
\text { Cahiers de } \\
\text { nutrition et de } \\
\text { diététique, } \\
\text { France }\end{array}$ & $\begin{array}{l}\text { Aliments « } \\
\text { ultra- } \\
\text { transformés» } \\
\text { et cancer. } \\
\text { Cahiers de } \\
\text { Nutrition et } \\
\text { Diététique. }\end{array}$ & $\begin{array}{l}\text { Cahiers de } \\
\text { Nutrition et } \\
\text { Diététique }\end{array}$ & $\begin{array}{l}\text { See journal Cahiers de } \\
\text { Nutrition et Diététique }\end{array}$ & & & $\begin{array}{l}\text { President of the Fond } \\
\text { Français pour } \\
\text { I'Alimentation et la Santé } \\
\text { (FFAS) } \\
\text { http://www.ria.fr/actualites/ils } \\
\text {-bougent/bernard-guy-grand- } \\
\text { president-du-ffas- } \\
\text { 1,4,3002609175.html } \\
\text { http://alimentation- } \\
\text { sante.org/ils-nous- } \\
\text { soutiennent/ } \\
\text { http://alimentation- } \\
\text { sante.org/quest-ce-que-le- } \\
\text { ffas/ }\end{array}$ \\
\hline $\begin{array}{l}\text { Miller Jones } \\
\text { Julie }\end{array}$ & $\begin{array}{l}\text { St. Catherine } \\
\text { University, } \\
\text { USA }\end{array}$ & $\begin{array}{l}\text { The Nutrition } \\
\text { Society, } \\
\text { Spring } \\
\text { Conference } \\
\text { 2018: } \\
\text { Nutrient- } \\
\text { nutrient } \\
\text { interaction, }\end{array}$ & $\begin{array}{l}\text { The Nutrition } \\
\text { Society } \\
+ \\
\text { AACCI }\end{array}$ & $\begin{array}{l}\text { Sessions of the BNS } \\
\text { sponsored by Yakult, } \\
\text { Fédération de I'Industrie } \\
\text { Alimentaire (FEVIA) and } \\
\text { Beneo Institute } \\
\text { Cereals } 17 \text { is organised by the }\end{array}$ & $\begin{array}{l}\text { Julie Miller Jones is a } \\
\text { scientific advisor to the } \\
\text { Grains Food } \\
\text { Foundation, The Healthy } \\
\text { Grains Institute (Canada), } \\
\text { Quaker Oats Advisory Board, } \\
\text { and the Campbell Soup } \\
\text { Company Plant and Health }\end{array}$ & $\begin{array}{l}\text { The concept and much } \\
\text { background for the present } \\
\text { paper resulted from work of } \\
\text { the Ad Hoc Joint Food and } \\
\text { Nutrition Science Solutions } \\
\text { Task Force (Task Force) } \\
\text { [2006-2016], representing the } \\
\text { Academy of Nutrition and }\end{array}$ & $\begin{array}{l}\text { https://grainfoodsfoundation. } \\
\text { org/experts/julie-miller-jones- } \\
\text { phd-ln-cns/: part of the } \\
\text { General Mills speaker's } \\
\text { bureau } \\
\text { For the national American } \\
\text { Association of Cereal } \\
\text { Chemists (AACC) }\end{array}$ \\
\hline
\end{tabular}


World Nutrition 2018;9(3):176-240

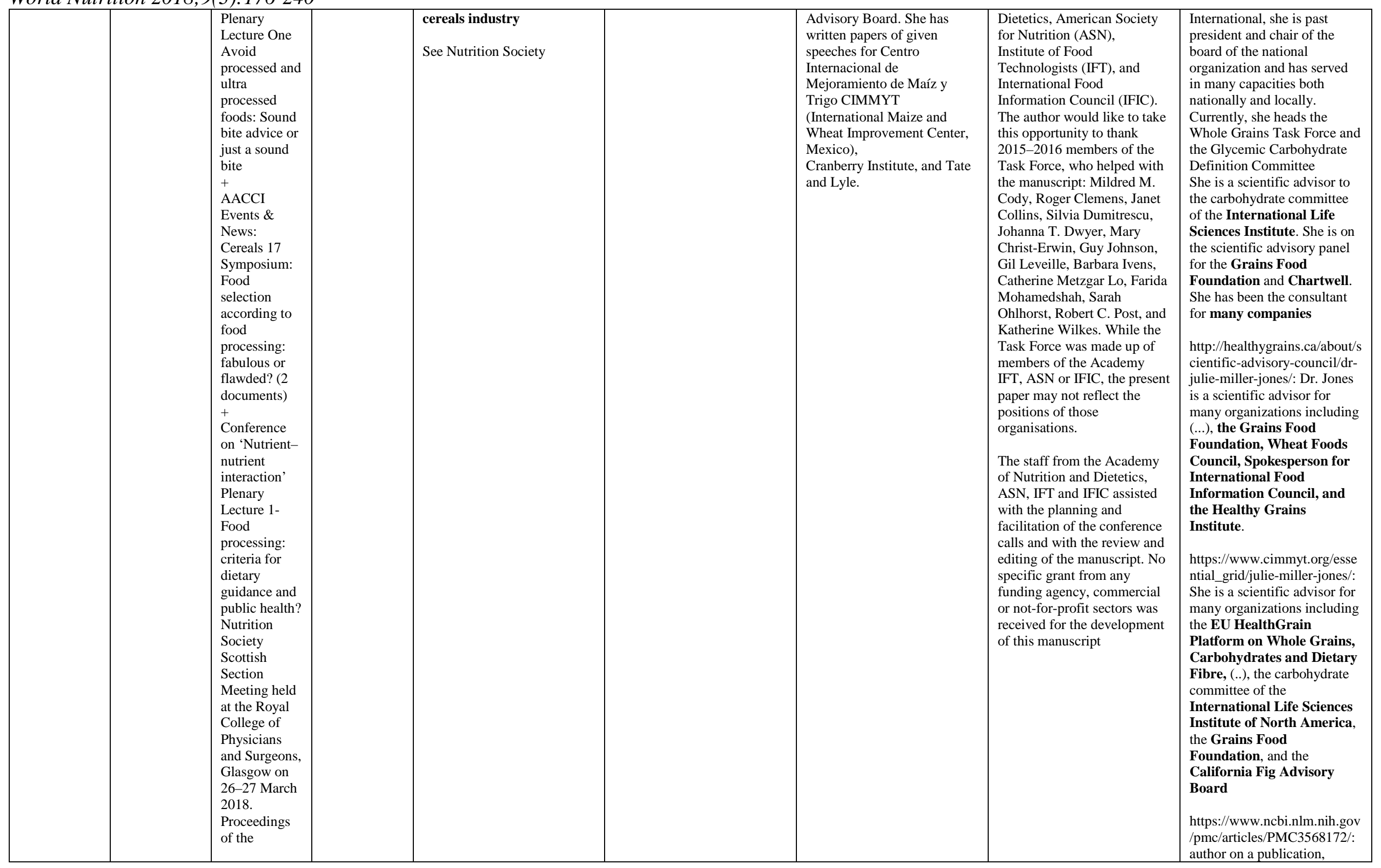


World Nutrition 2018;9(3):176-240

\begin{tabular}{|c|c|c|c|c|c|c|}
\hline & & $\begin{array}{l}\text { Nutrition } \\
\text { Society. }\end{array}$ & & & & $\begin{array}{l}\text { where she received funding } \\
\text { for travel to the workshop } \\
\text { from ILSI }\end{array}$ \\
\hline Keast Debra & $\begin{array}{l}\text { Food \& } \\
\text { Nutrition } \\
\text { Database } \\
\text { Research, Inc. } \\
\text { USA }\end{array}$ & $\begin{array}{l}\text { Contributions } \\
\text { of Processed } \\
\text { Foods to } \\
\text { Dietary } \\
\text { Intake in the } \\
\text { US from } \\
\text { 2003-2008: } \\
\text { A Report of } \\
\text { the Food and } \\
\text { Nutrition } \\
\text { Science } \\
\text { Solutions } \\
\text { Joint Task } \\
\text { Force of the } \\
\text { Academy of } \\
\text { Nutrition and } \\
\text { Dietetics, } \\
\text { American } \\
\text { Society for } \\
\text { Nutrition, } \\
\text { Institute of } \\
\text { Food } \\
\text { Technologists } \\
\text {, and } \\
\text { International } \\
\text { Food } \\
\text { Information } \\
\text { Council. } \\
\text { Journal of } \\
\text { Nutrition. } \\
+ \\
\text { Processed } \\
\text { Food } \\
\text { Contributions } \\
\text { to Energy and } \\
\text { Nutrient } \\
\text { Intake Differ } \\
\text { among US } \\
\text { Children by } \\
\text { Race/Ethnicit } \\
\text { y. Nutrients. } \\
+ \\
\text { Energy and } \\
\text { Nutrient } \\
\text { Intakes from } \\
\text { Processed } \\
\text { Foods Differ } \\
\text { by Sex, }\end{array}$ & $\begin{array}{l}\text { The Journal } \\
\text { of Nutrition } \\
\text { from the ASN } \\
+ \\
\text { journal } \\
\text { Nutrients } \\
+ \\
\text { Journal of the } \\
\text { Academy of } \\
\text { Nutrition and } \\
\text { Dietetics }\end{array}$ & $\begin{array}{l}\text { See Journal of the American } \\
\text { Society for Nutrition }\end{array}$ & $\begin{array}{l}\text { President of Food and } \\
\text { Nutrition Database Research, } \\
\text { Inc. was subcontracted by } \\
\text { Nutrition Impact, LLC to } \\
\text { conduct this research and } \\
\text { other research funded } \\
\text { indirectly by the } \\
\text { International Life Sciences } \\
\text { Institute-North America } \\
\text { (ILSI-NA) (nutrient paper) }\end{array}$ & $\begin{array}{l}\text { No webiste for that company, } \\
\text { but the President of that } \\
\text { company has published } \\
\text { several papers in the field, } \\
\text { many with the ASN, and } \\
\text { many with people closed to } \\
\text { the industry } \\
\text { https://www.linkedin.com/in/ } \\
\text { debra-r-keast-phd-a8564412 }\end{array}$ \\
\hline
\end{tabular}


World Nutrition 2018;9(3):176-240

\begin{tabular}{|c|c|c|c|c|c|c|}
\hline & & $\begin{array}{l}\text { Income } \\
\text { Status, and } \\
\text { Race/Ethnicit } \\
\text { y of US } \\
\text { Adults. } \\
\text { Journal of the } \\
\text { Academy of } \\
\text { Nutrition and } \\
\text { Dietetics. }\end{array}$ & & & & \\
\hline King Janet & $\begin{array}{l}\text { University of } \\
\text { California, } \\
\text { Davis, and } \\
\text { Children's } \\
\text { Hospital } \\
\text { Oakland } \\
\text { Research } \\
\text { Institute, } \\
\text { USA }\end{array}$ & $\begin{array}{l}\text { Processed } \\
\text { foods: } \\
\text { contributions } \\
\text { to nutrition. } \\
\text { American } \\
\text { Journal of } \\
\text { Clinical } \\
\text { Nutrition. }\end{array}$ & $\begin{array}{l}\text { American } \\
\text { Journal of } \\
\text { Clinical } \\
\text { Nutrition }\end{array}$ & $\begin{array}{l}\text { See Journal of the American } \\
\text { Society for Nutrition }\end{array}$ & & $\begin{array}{l}\text { Give presentations for ILSI } \\
\text { SEA region: } \\
\text { http://ilsisea-region.org/wp- } \\
\text { content/uploads/sites/21/2017 } \\
\text { /10/LSI-SEA-Region- } \\
\text { Newsletter-October-2017.pdf } \\
\text { http://ilsisea-region.org/wp- } \\
\text { content/uploads/sites/21/2017 } \\
\text { /05/01-Janet-King.pdf } \\
\text { Council member of the } \\
\text { Nestlé Foundation (2012): } \\
\text { https://www.nestlefoundation } \\
\text {.org/docs/AnnualReport2012. } \\
\text { pdf }\end{array}$ \\
\hline $\begin{array}{l}\text { Lecerf Jean } \\
\text { Michel }\end{array}$ & $\begin{array}{l}\text { Institut } \\
\text { Pasteur de } \\
\text { Lille, France }\end{array}$ & $\begin{array}{l}\text { Les aliments } \\
\text { hyper- } \\
\text { transformés : } \\
\text { un nouveau } \\
\text { concept } \\
\text { discuté. } \\
\text { Médecine des } \\
\text { Maladies } \\
\text { Métaboliques. }\end{array}$ & $\begin{array}{l}\text { Journal } \\
\text { Medecine des } \\
\text { maladies } \\
\text { metaboliques }\end{array}$ & & $\begin{array}{l}\text { The Institut Pasteur de Lille } \\
\text { has many links with the } \\
\text { industry See paper } \\
\text { https://www.cambridge.org/c } \\
\text { ore/journals/public-health- } \\
\text { nutrition/article/corporate- } \\
\text { political-activity-of-the-dairy- } \\
\text { industry-in-france-an- } \\
\text { analysis-of-publicly- } \\
\text { available- } \\
\text { information/400B6107C8859 } \\
\text { B9E8B62110E0B5D5EF6htt } \\
\text { ps://www.lesjfn.fr/print- } \\
\text { fullConference supported } \\
\text { by Danone, Nestle } \\
\text { https://nutrition.pasteur- } \\
\text { lille.fr/fileadmin/user_upload/ } \\
\text { programme_entretiens_de_nu } \\
\text { trition-final.pdf } \\
\text { Interbev, CERIN, CEDUS, } \\
\text { Aprifel, Foundation } \\
\text { Bonduelle, Florette Food } \\
\text { Servicehttps://www.pasteur- } \\
\text { lille.fr/nous- } \\
\text { soutenir/mecenat/Institute }\end{array}$ & $\begin{array}{l}\text { Scientific committee } \\
\text { Lactalis, Danone, Holder, } \\
\text { Thermes de Brides les } \\
\text { Bains, Avenance, Compass, } \\
\text { Accor, Tourpagel, Lidl, } \\
\text { Sanofi, MDS, Roche, } \\
\text { AbbottResearch for: } \\
\text { Lactalis, Roquette, } \\
\text { Bonduelle, Yoplait, } \\
\text { Witaxos, Phytobocaz, } \\
\text { Master Foods, Lesaffre, } \\
\text { Fondimare, IFIP, } \\
\text { Distriborg, Synadiet, } \\
\text { Chambre Syndicale de la } \\
\text { Margarine } \\
\text { https://www.anses.fr/sites/def } \\
\text { ault/files/DPI-Ft- } \\
\text { LECERFJean-Michel.pdf } \\
\text { Member of the scientific } \\
\text { committee for a front group } \\
\text { of the dairy industry: } \\
\text { http://www.lemangeur- } \\
\text { ocha.com/auteur/jean-michel- } \\
\text { lecerf/Member of the } \\
\text { scientific committee of }\end{array}$ \\
\hline
\end{tabular}


World Nutrition 2018;9(3):176-240

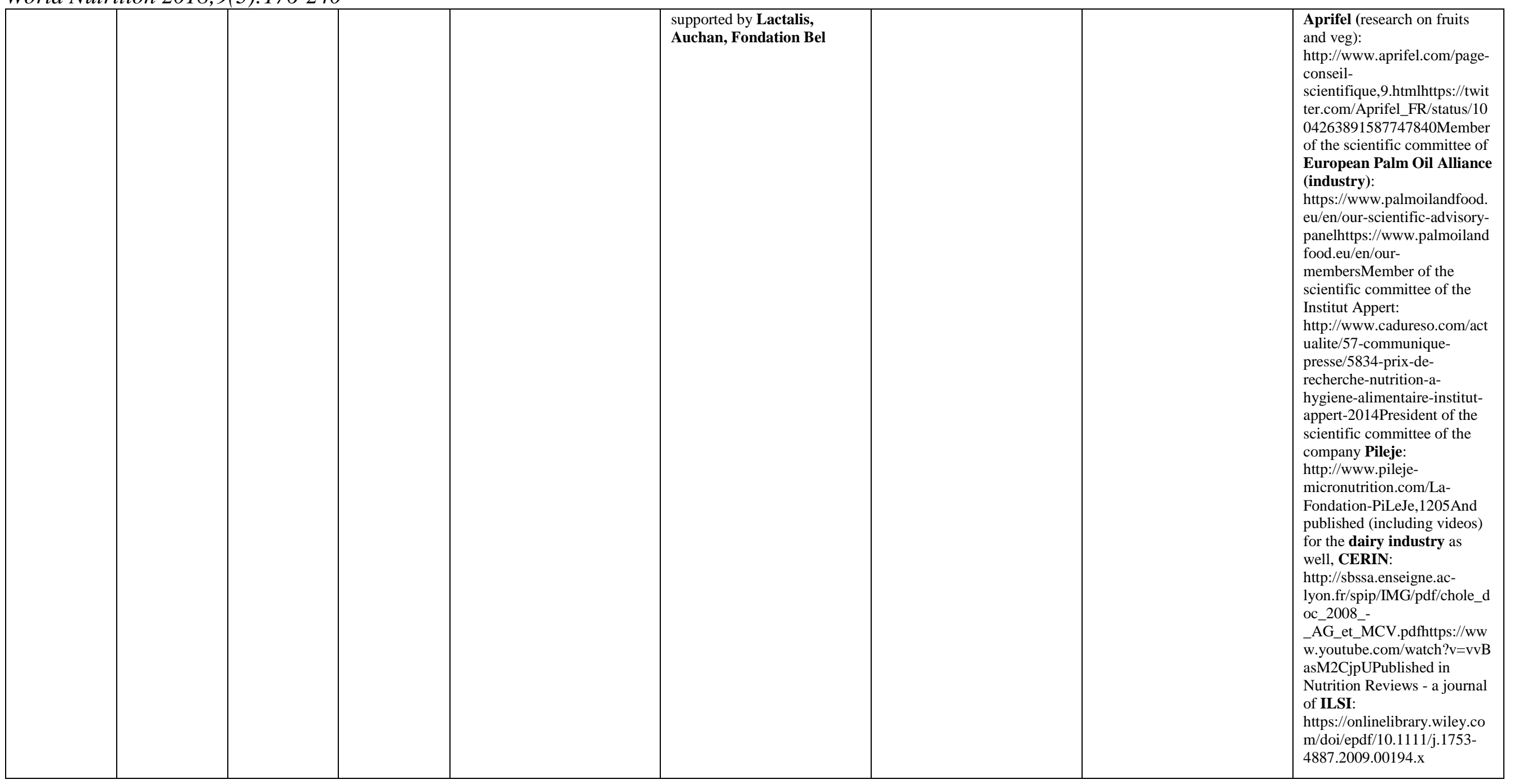


World Nutrition 2018;9(3):176-240

\begin{tabular}{|c|c|c|c|c|c|c|c|}
\hline $\begin{array}{l}\text { Leveille } \\
\text { Gilbert }\end{array}$ & $\begin{array}{l}\text { Leveille } \\
\text { Associates, } \\
\text { Denville, } \\
\text { USA }\end{array}$ & $\begin{array}{l}\text { Processed } \\
\text { foods: } \\
\text { contributions } \\
\text { to nutrition. } \\
\text { American } \\
\text { Journal of } \\
\text { Clinical } \\
\text { Nutrition. }\end{array}$ & $\begin{array}{l}\text { American } \\
\text { Journal of } \\
\text { Clinical } \\
\text { Nutrition }\end{array}$ & $\begin{array}{l}\text { See Journal of the American } \\
\text { Society for Nutrition }\end{array}$ & $\begin{array}{l}\text { https://www.linkedin.com/in/ } \\
\text { gilbert-leveille-phd-7179713 } \\
\text { President, Leveille } \\
\text { Associates, } 1996 \text { - o } \\
\text { momento (22 anos)Denville, } \\
\text { NJ, Food and Nutrition } \\
\text { Consultation }\end{array}$ & $\begin{array}{l}\text { GA Leveille, serves on } \\
\text { scientific advisory boards for } \\
\text { Hillshire Brands and the } \\
\text { McCormick Science } \\
\text { Institute }\end{array}$ & $\begin{array}{l}\text { https://www.linkedin.com/in/ } \\
\text { gilbert-leveille-phd-7179713 } \\
\\
\text { Past President, Institute of } \\
\text { Food Technologists, } 1971 \text { - } \\
\text { o momento (47 anos), } \\
\text { Wrigley Science Institute } \\
\text { Executive Director, Wrigley } \\
\text { Science Institute, } 2004 \text { - } \\
2010 \text { (6 anos) } \\
\text { VP technology, Cargill, } 2002 \\
\text { - } 2007 \text { (5 anos) } \\
\text { WorldWide VP Regulatory \& } \\
\text { Scientific Affairs, McNeil } \\
\text { Nutritionals, 1999 - 2001 (2 } \\
\text { anos)Fort Washington, PA, } \\
\text { Responsible for worldwide } \\
\text { regulatory activities and } \\
\text { science } \\
\text { VP, Research \& Technical } \\
\text { Services, Nabisco, 1988 - } \\
1996 \text { (8 anos)East Hanover, } \\
\text { NJ, Responsible for } \\
\text { fundamental research, } \\
\text { extrusion research and } \\
\text { scientific services } \\
\text { Past President, American } \\
\text { Society for Nutriion, 1988 - } \\
1989 \text { (1 ano) }\end{array}$ \\
\hline $\begin{array}{l}\text { MacDonald } \\
\text { Ruth }\end{array}$ & $\begin{array}{l}\text { Iowa State } \\
\text { University, } \\
\text { USA }\end{array}$ & $\begin{array}{l}\text { Processed } \\
\text { foods: } \\
\text { contributions } \\
\text { to nutrition. } \\
\text { American } \\
\text { Journal of } \\
\text { Clinical } \\
\text { Nutrition. }\end{array}$ & $\begin{array}{l}\text { American } \\
\text { Journal of } \\
\text { Clinical } \\
\text { Nutrition }\end{array}$ & $\begin{array}{l}\text { See Journal of the American } \\
\text { Society for Nutrition }\end{array}$ & & & \\
\hline
\end{tabular}


World Nutrition 2018;9(3):176-240

\begin{tabular}{|c|c|c|c|c|c|}
\hline Madi Luis & ITAL, Brazil & $\begin{array}{l}\text { The Myth of } \\
\text { Ultra- } \\
\text { Processed } \\
\text { Foods. EC } \\
\text { Nutrition. } \\
+ \\
\text { Brasil } \\
\text { Processed } \\
\text { Food } 2020 \\
\text { a. publication: } \\
\text { ITAL. } \\
\text { Alimentos } \\
\text { industrualuza } \\
\text { dos: a } \\
\text { importancia } \\
\text { para a } \\
\text { sociedade } \\
\text { brasileira . } \\
\text { Editores: } \\
\text { Rego R. A., } \\
\text { Vialta A. and } \\
\text { Madi L. 2018. } \\
\text { http://aliment } \\
\text { osindustrializ } \\
\text { ados.com.br/2 } \\
\text { / } \\
\text { b. website: } \\
\text { http://www.al } \\
\text { imentosproce } \\
\text { ssados.com.br } \\
\text { /plataforma.p } \\
\text { hp } \\
+ \\
\text { Brasil } \\
\text { Processed } \\
\text { Food 2020: } \\
\text { um projeto } \\
\text { em defesa da } \\
\text { industrializaç } \\
\text { ão de } \\
\text { alimentos. } \\
\text { Brazilian } \\
\text { Journal of } \\
\text { Food } \\
\text { Technology. }\end{array}$ & $\begin{array}{l}\text { EC Nutrition : Predatory } \\
\text { journal }\end{array}$ & $\begin{array}{l}\text { With technical and scientific } \\
\text { information, without value } \\
\text { judgments or conflicts of } \\
\text { interest, the knowledge in } \\
\text { greater detail about the } \\
\text { products and their ingredients } \\
\text { and forms of processing can } \\
\text { serve as support to the } \\
\text { purchasing decisions of the } \\
\text { Brazilian consumers, in the } \\
\text { exercise of their free will }\end{array}$ & $\begin{array}{l}\text { Equipe Técnica do Brasil } \\
\text { Food Trends } \\
\text { see Raul Rego } \\
\\
\text { http://www.ital.sp.gov.br/noti } \\
\text { cias.php?not_id=661 } \\
\text { Brasil Processed Food 2020: } \\
\text { protocolo de intenção com a } \\
\text { Associação Brasileira das } \\
\text { Indústrias da Alimentação } \\
\text { (Abia) } \\
\text { O protocolo tem duração de } \\
\text { três anos, e assinaram como } \\
\text { testemunhas o diretor do Ital, } \\
\text { Luís Fernando Madi; o } \\
\text { diretor superintendente da } \\
\text { Associação Brasileira das } \\
\text { Empresas de Refeições } \\
\text { Coletivas, Antônio } \\
\text { Guimarães; o diretor técnico } \\
\text { da Associação Brasileira de } \\
\text { Proteína Animal, Ariel } \\
\text { Antônio Mendes; o vice- } \\
\text { presidente da Associação } \\
\text { Brasileira da indústria de } \\
\text { Embalagens Plásticas, Beni } \\
\text { Adler; o presidente da } \\
\text { Associação Brasileira da } \\
\text { Indústria de Alimentos para } \\
\text { Fins Especiais e } \\
\text { Congêneres, Carlos Eduardo } \\
\text { Gouvêa; o gerente executivo } \\
\text { da Associação Brasileira das } \\
\text { Indústrias de Biscoito, } \\
\text { Massas Alimentícias e Pães } \\
\text { \& Bolos Insudtrializados, } \\
\text { Edgard Sanchez; o presidente } \\
\text { da Associação Brasileira de } \\
\text { Marketing Rural e } \\
\text { Agronegócio, Daniel } \\
\text { Baptistella; o diretor } \\
\text { executivo da Associação } \\
\text { Nacional de Defesa Vegetal } \\
\text { Eduardo Daher; o presidente } \\
\text { da Associação Brasileira das } \\
\text { Indústrias de Queijo, Fábio } \\
\text { Scarcelli; o diretor executivo } \\
\text { da Associação Brasileira do } \\
\text { Agronegócio, Luiz Antônio } \\
\text { Beltrati Cornacchioni; o } \\
\text { assessor técnico da } \\
\end{array}$ \\
\hline
\end{tabular}


World Nutrition 2018;9(3):176-240

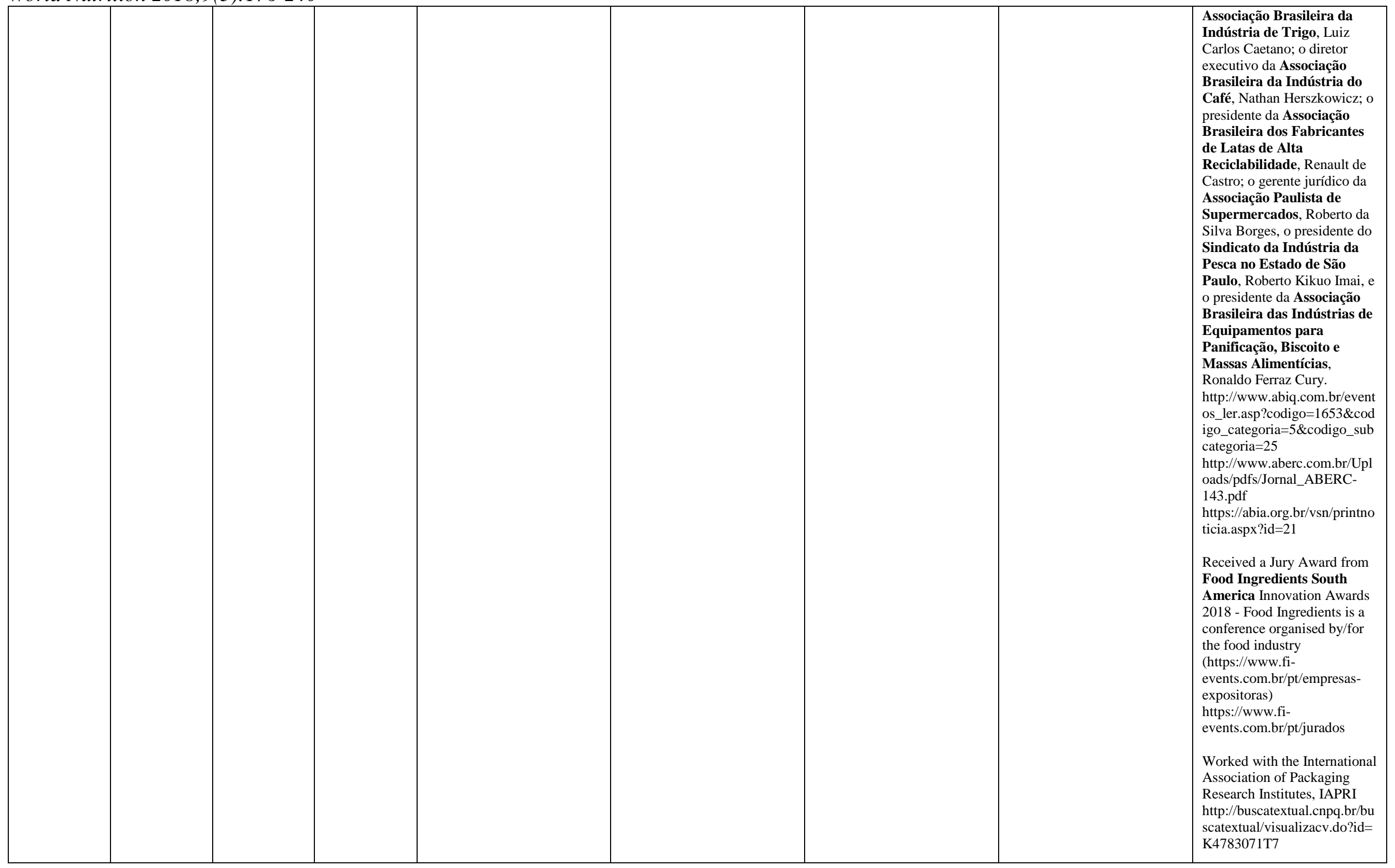


World Nutrition 2018;9(3):176-240

\begin{tabular}{|c|c|c|c|c|c|c|}
\hline $\begin{array}{l}\text { Martins } \\
\text { Carolina }\end{array}$ & $\begin{array}{l}\text { Unknown, } \\
\text { was working } \\
\text { with the } \\
\text { University of } \\
\text { São Paulo, } \\
\text { Brazil at the } \\
\text { time of } \\
\text { publication }\end{array}$ & $\begin{array}{l}\text { Comparison } \\
\text { of Child } \\
\text { Lunch Meals } \\
\text { in Brazil. } \\
\text { Food and } \\
\text { Nutrition } \\
\text { Sciences. }\end{array}$ & & & $\begin{array}{l}\text { The authors acknowledge } \\
\text { Equilibrium Consultancy } \\
\text { which led this study. Funding } \\
\text { by McDonald's Corporation } \\
\text { for the project was primarily } \\
\text { to Equilibrium. }\end{array}$ & No information online \\
\hline Morán Javier & $\begin{array}{l}\text { Universidad } \\
\text { Católica San } \\
\text { Antonio de } \\
\text { Murcia, } \\
\text { Spain }\end{array}$ & $\begin{array}{l}\text { Acerca de los } \\
\text { sistemas de } \\
\text { clasificación } \\
\text { de alimentos } \\
\text { y su } \\
\text { racionalidad } \\
\text { científica }\end{array}$ & IFAN Chile & $\begin{array}{l}\text { Yes, public-private initative } \\
\text { http://ifan.cl/quienes-somos/ }\end{array}$ & & $\begin{array}{l}\text { Tras trabajar } 15 \text { años en la } \\
\text { industria alimentaria, en } \\
\text { distintas posiciones, en } \\
\text { Latinoamérica y Europa, } \\
\text { desde } 1998 \text { es Socio-Director } \\
\text { de Food Consulting \& } \\
\text { Associates. } \\
\text { http://www.nutraceuticalseur } \\
\text { ope.com/wp- } \\
\text { content/uploads/2016/09/CV- } \\
\text { bilingüe-JMorán.pdf } \\
\text { http://www.foodconsulting.es } \\
\text { Participated in conferences } \\
\text { sponsored by the food } \\
\text { industry } \\
\text { http://www.foodconsulting.es } \\
\text { /probiota-2018/ } \\
\text { http://www.foodconsulting.es } \\
\text { /wp- } \\
\text { content/uploads/programapro } \\
\text { biota18.pdf } \\
\text { Granotec } \\
\text { http://icn2017.com/docs/preli } \\
\text { minary_sponsored_programm } \\
\text { e.pdf } \\
\text { https://www.fdf.org.uk/events } \\
\text { /HCNP.pdf } \\
\text { Research funded by the } \\
\text { industry: Gallina Blanca } \\
\text { STAR (GBST), Grupo } \\
\text { Carinsa, WILD Valencia, } \\
\text { S.A, Probelte bio, } \\
\text { Ibermática, 2BBlackBio, Go } \\
\text { Fruselva S.L.U, Asturiana, } \\
\text { Biocentury S.L.U } \\
\text { https://www.nutraingredients. } \\
\text { com/Article/2012/01/05/Oliv } \\
\text { e-oil-extract-space-gains- } \\
\text { another-player } \\
\text { http://www.henufood.com/pa }\end{array}$ \\
\hline
\end{tabular}




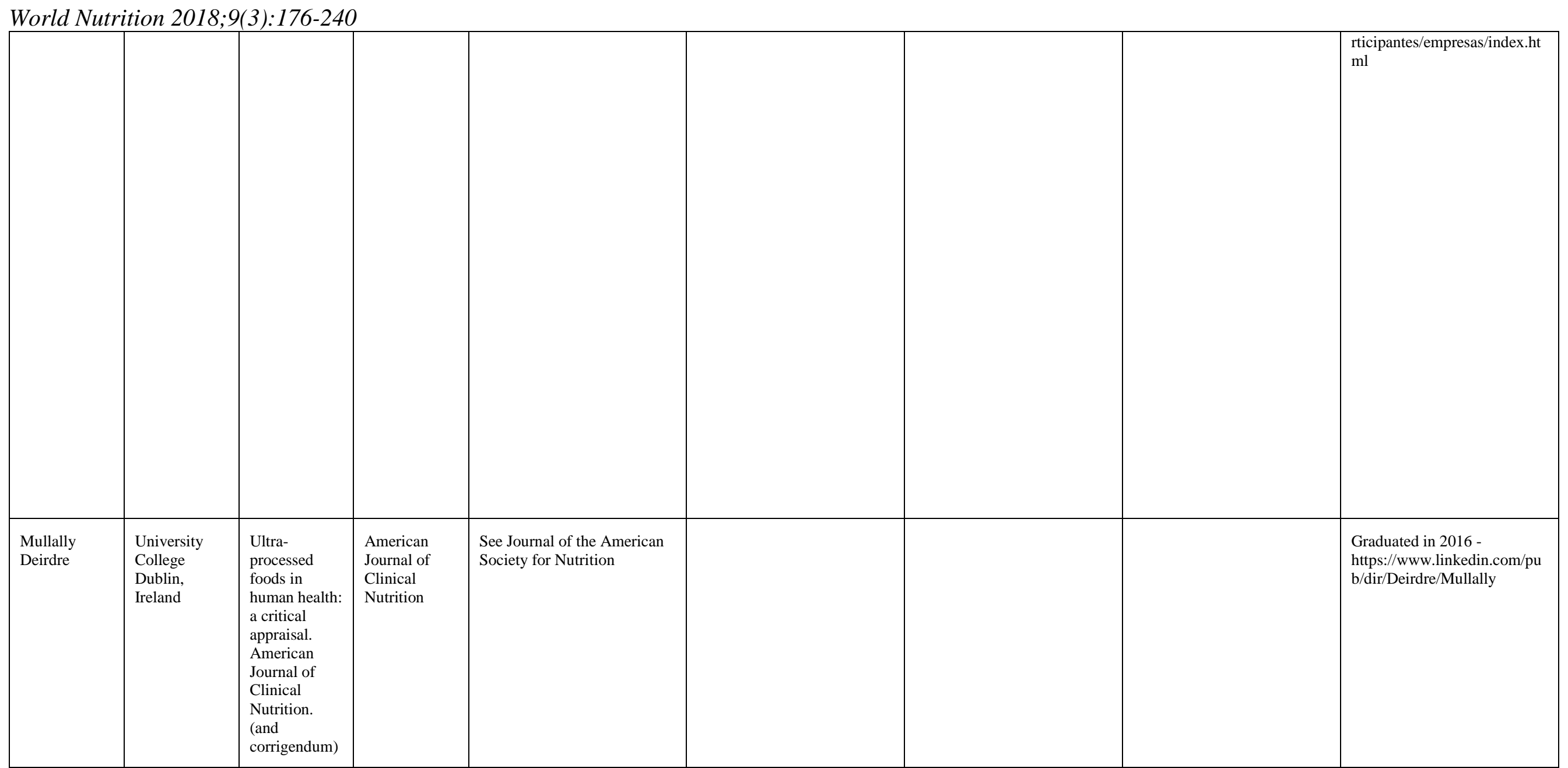


World Nutrition 2018;9(3):176-240

\begin{tabular}{|c|c|c|c|c|c|}
\hline Ordovas Jose & $\begin{array}{l}\text { Office of } \\
\text { Dietary } \\
\text { Supplements, } \\
\text { NIH, USA }\end{array}$ & $\begin{array}{l}\text { Processed } \\
\text { foods: } \\
\text { contributions } \\
\text { to nutrition. } \\
\text { American } \\
\text { Journal of } \\
\text { Clinical } \\
\text { Nutrition. }\end{array}$ & $\begin{array}{l}\text { American } \\
\text { Journal of } \\
\text { Clinical } \\
\text { Nutrition }\end{array}$ & $\begin{array}{l}\text { See Journal of the American } \\
\text { Society for Nutrition }\end{array}$ & $\begin{array}{l}\text { Presented at ILSI events: } \\
\text { http://ilsi.org/event//experime } \\
\text { ntal-biology-2016-2/ } \\
\text { http://ilsi.org/event/ilsi-north- } \\
\text { america-mid-year-meeting/ } \\
\text { http://ilsi.org/event/big-data- } \\
\text { and-other-innovative- } \\
\text { approaches-to-understanding- } \\
\text { dietary-patterns-and-health/ } \\
\text { Publications funded by ILSI: } \\
\text { https://academic.oup.com/ajc } \\
\text { n/article/89/5/1509S/4596902 } \\
\text { : Funds to support the writing } \\
\text { of this manuscript were } \\
\text { provided in part by the } \\
\text { Project Committee on Early } \\
\text { Nutrition of the } \\
\text { International Life Sciences } \\
\text { Institute North American } \\
\text { Branch. }\end{array}$ \\
\hline
\end{tabular}


World Nutrition 2018;9(3):176-240

\begin{tabular}{|c|c|c|c|c|c|c|c|}
\hline $\begin{array}{l}\text { Rego Raul } \\
\text { Amaral }\end{array}$ & ITAL, Brazil & $\begin{array}{l}\text { The Myth of } \\
\text { Ultra- } \\
\text { Processed } \\
\text { Foods. EC } \\
\text { Nutrition. } \\
\text { +Brasil } \\
\text { Processed } \\
\text { Food 2020a. } \\
\text { publication: } \\
\text { ITAL. } \\
\text { Alimentos } \\
\text { industrualuza } \\
\text { dos: a } \\
\text { importancia } \\
\text { para a } \\
\text { sociedade } \\
\text { brasileira. } \\
\text { Editores: } \\
\text { Rego R. A., } \\
\text { Vialta A. and } \\
\text { Madi L. 2018. } \\
\text { http://aliment } \\
\text { osindustrializ } \\
\text { ados.com.br/2 } \\
\text { /b. website: } \\
\text { http://www.al } \\
\text { imentosproce } \\
\text { ssados.com.br } \\
\text { /plataforma.p } \\
\text { hp } \\
\text { +Brasil } \\
\text { Processed } \\
\text { Food 2020: } \\
\text { um projeto } \\
\text { em defesa da } \\
\text { industrializaç } \\
\text { ão de } \\
\text { alimentos. } \\
\text { Brazilian } \\
\text { Journal of } \\
\text { Food } \\
\text { Technology. }\end{array}$ & & $\begin{array}{l}\text { EC Nutrition : Predatory } \\
\text { journal }\end{array}$ & & $\begin{array}{l}\text { With technical and scientific } \\
\text { information, without value } \\
\text { judgments or conflicts of } \\
\text { interest, the knowledge in } \\
\text { greater detail about the } \\
\text { products and their ingredients } \\
\text { and forms of processing can } \\
\text { serve as support to the } \\
\text { purchasing decisions of the } \\
\text { Brazilian consumers, in the } \\
\text { exercise of their free will }\end{array}$ & $\begin{array}{l}\text { Equipe Técnica do Brasil } \\
\text { Food TrendsOne of the } \\
\text { coordenadoresPatrocinadores: } \\
\text { ABIC, ABLV, Cargill, } \\
\text { Coca-Cola, Danone, Fispal } \\
\text { Tecnologia, Grupo Pao de } \\
\text { Azucar, Fundepag, Jenkor, } \\
\text { JBS, M Cassab, MDF, } \\
\text { Monsanto, Nestle, } \\
\text { Sindicarnes, } \\
\text { Tetrapackhttp://www.brasilf } \\
\text { oodtrends.com.br/equipetecni } \\
\text { ca.htmlApoio tecnico: ABIA, } \\
\text { APAS, ECD, ESPM, FOOD } \\
\text { designhttp://www.brasilfoodt } \\
\text { rends.com.br/publicacao.html } \\
\text { Brasil Processed Food 2020, } \\
\text { see Luis MadiParticipação } \\
\text { ativa no congresso e Prêmio } \\
\text { SBAN } \\
\text { ILSIhttp://ilsibrasil.org/wp- } \\
\text { content/uploads/sites/9/2016/ } \\
\text { 10/boletim__ilsi_19_alta.pdfPa } \\
\text { rticipated in many events } \\
\text { organised for/by industry } \\
\text { actors: Latin America } \\
\text { Symposium of Food } \\
\text { Science, SIAL Brazil, } \\
\text { Vitafoods South } \\
\text { Americahttt://buscatextual.c } \\
\text { npq.br/buscatextual/visualiza } \\
\text { cv.do?id=K4785940P5 }\end{array}$ \\
\hline Romero Jairo & $\begin{array}{l}\text { ALACCTA } \\
\text { Asociación } \\
\text { Latinoameric } \\
\text { ana y del } \\
\text { Caribe de } \\
\text { Ciencia y }\end{array}$ & $\begin{array}{l}\text { Comentarios } \\
\text { al Proyecto de } \\
\text { Ley 07 de } \\
2017, \\
\text { audiencia } \\
\text { publica de la } \\
\text { comisión }\end{array}$ & $\begin{array}{l}\text { Colombian } \\
\text { Senate }\end{array}$ & & Yes, food industry trade assoc & & $\begin{array}{l}\text { Presented for ILSI in } 2018 \\
\text { http://ilsibrasil.org/wp- } \\
\text { content/uploads/sites/9/2018/ } \\
\text { 04/Dr.-Jairo-Romero-Data- } \\
\text { and-Emotions.pdf } \\
\text { And earlier } \\
\text { http://ilsinorandino.org/wp- }\end{array}$ \\
\hline
\end{tabular}


World Nutrition 2018;9(3):176-240

\begin{tabular}{|c|c|c|c|c|c|c|c|}
\hline & $\begin{array}{l}\text { Technologia } \\
\text { de Alimentos }\end{array}$ & $\begin{array}{l}\text { séptima del } \\
\text { senado de la } \\
\text { republica de } \\
\text { Colombia, } \\
\text { Octubre } 26 \text { de } \\
2017\end{array}$ & & & & & $\begin{array}{l}\text { content/uploads/sites/16/2016 } \\
\text { /12/La-ciencia-detrás-de- } \\
\text { regulaciones-Jairo- } \\
\text { Romero.pdf }\end{array}$ \\
\hline $\begin{array}{l}\text { Sanchez } \\
\text { Oliveira } \\
\text { Jensen } \\
\text { Natália }\end{array}$ & $\begin{array}{l}\text { Translator for } \\
\text { ACME, } \\
\text { Brazil }\end{array}$ & $\begin{array}{l}\text { Comparison } \\
\text { of Child } \\
\text { Lunch Meals } \\
\text { in Brazil. } \\
\text { Food and } \\
\text { Nutrition } \\
\text { Sciences. }\end{array}$ & & & & $\begin{array}{l}\text { The authors acknowledge } \\
\text { Equilibrium Consultancy } \\
\text { which led this study. Funding } \\
\text { by McDonald's Corporation } \\
\text { for the project was primarily } \\
\text { to Equilibrium. }\end{array}$ & $\begin{array}{l}\text { Graduated from USP, Brazil } \\
\text { in } 2014 \\
\text { https://br.linkedin.com/in/nat } \\
\text { aliasanchezoliveirajensen }\end{array}$ \\
\hline $\begin{array}{l}\text { Schmidt } \\
\text { David }\end{array}$ & $\begin{array}{l}\text { International } \\
\text { Food } \\
\text { Information } \\
\text { Council, USA }\end{array}$ & $\begin{array}{l}\text { Is } \\
\text { "Processed" a } \\
\text { Four-Letter } \\
\text { Word? The } \\
\text { Role of } \\
\text { Processed } \\
\text { Foods in } \\
\text { Achieving } \\
\text { Dietary } \\
\text { Guidelines } \\
\text { and Nutrient } \\
\text { Recommenda } \\
\text { tions. } \\
\text { American } \\
\text { Society for } \\
\text { Nutrition. } \\
\text { Advances in } \\
\text { Nutrition. }\end{array}$ & $\begin{array}{l}\text { Advances in } \\
\text { Nutrition }\end{array}$ & $\begin{array}{l}\text { See Journal of the American } \\
\text { Society for Nutrition }\end{array}$ & $\begin{array}{l}\text { https://www.foodinsight.org/a } \\
\text { bout\#block-block-17 } \\
\text { IFIC Supporters: IFIC is } \\
\text { supported by the following } \\
\text { companies from the broad- } \\
\text { based food, beverage and } \\
\text { agricultural industries: } \\
\text { Abbott Nutrition, Atkins } \\
\text { Nutritionals, Inc., Barilla } \\
\text { Group } \\
\text { Bayer CropScience LP, } \\
\text { Cargill, Incorporated, } \\
\text { Chobani, The Coca-Cola } \\
\text { Company, Compass Group, } \\
\text { Danone North America PBC, } \\
\text { Dow AgroSciences, LLC, } \\
\text { DSM, DuPont Nutrition \& } \\
\text { Health, Ferrero USA, General } \\
\text { Mills, Inc., Heartland Food } \\
\text { Products Group, The Hershey } \\
\text { Company } \\
\text { HYET Sweet, Mars, } \\
\text { Incorporated, McCormick \& } \\
\text { Company, Inc., McKee } \\
\text { Foods, Mondelēz } \\
\text { International, PepsiCo, Red } \\
\text { Bull North America, Subway, } \\
\text { Yum! Brands, Zoetis }\end{array}$ & $\begin{array}{l}\text { The ASN symposium was co- } \\
\text { sponsored by the Institute of } \\
\text { Food Technologists (IFT) } \\
\text { and the International Food } \\
\text { Information Council (IFIC). } \\
\text { (...) funds to support this } \\
\text { publication were provided by } \\
\text { an educational grant from the } \\
\text { Campbell Soup Company. } \\
\text { The symposium was chaired } \\
\text { by Guy Johnson and Janet } \\
\text { King. The Guest Editor for } \\
\text { this symposium was Connie } \\
\text { Weaver. Guest Editor } \\
\text { disclosure: Connie Weaver } \\
\text { received research grants from } \\
\text { Dairy Management Inc. and } \\
\text { Nestle, and is on the } \\
\text { Scientific Advisory Board for } \\
\text { Pharmavite. }\end{array}$ & $\begin{array}{l}\text { Schmidt also gained a } \\
\text { thorough understanding of the } \\
\text { food industry in previous } \\
\text { sales positions with leading } \\
\text { food and beverage firms, } \\
\text { Oscar Mayer Foods, Pepsi- } \\
\text { Cola USA and Canada Dry } \\
\text { Corporation. } \\
\text { https://www.foodinsight.org/ } \\
\text { users/david-b-schmidt } \\
\text { Presented at an ILSI Brazil } \\
\text { event } \\
\text { http://www.fsp.usp.br/site/dc } \\
\text { ms/fck/file/comunica-e-risco- } \\
\text { 14.pdf }\end{array}$ \\
\hline $\begin{array}{l}\text { Schnakenberg } \\
\text { David }\end{array}$ & Unknown & $\begin{array}{l}\text { Processed } \\
\text { foods: } \\
\text { contributions } \\
\text { to nutrition. } \\
\text { American } \\
\text { Journal of }\end{array}$ & $\begin{array}{l}\text { American } \\
\text { Journal of } \\
\text { Clinical } \\
\text { Nutrition }\end{array}$ & $\begin{array}{l}\text { See Journal of the American } \\
\text { Society for Nutrition }\end{array}$ & & & \\
\hline
\end{tabular}




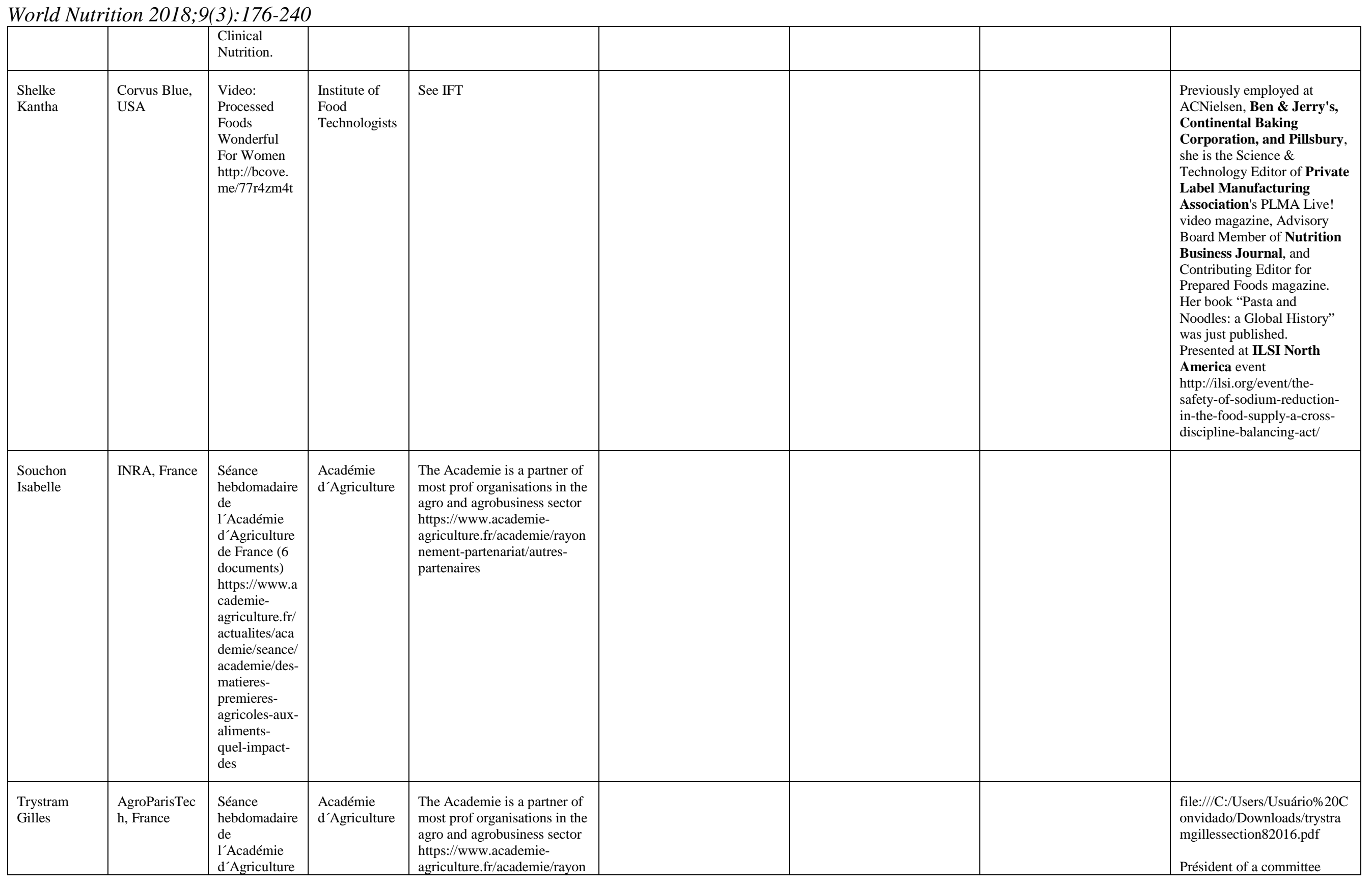


World Nutrition 2018;9(3):176-240

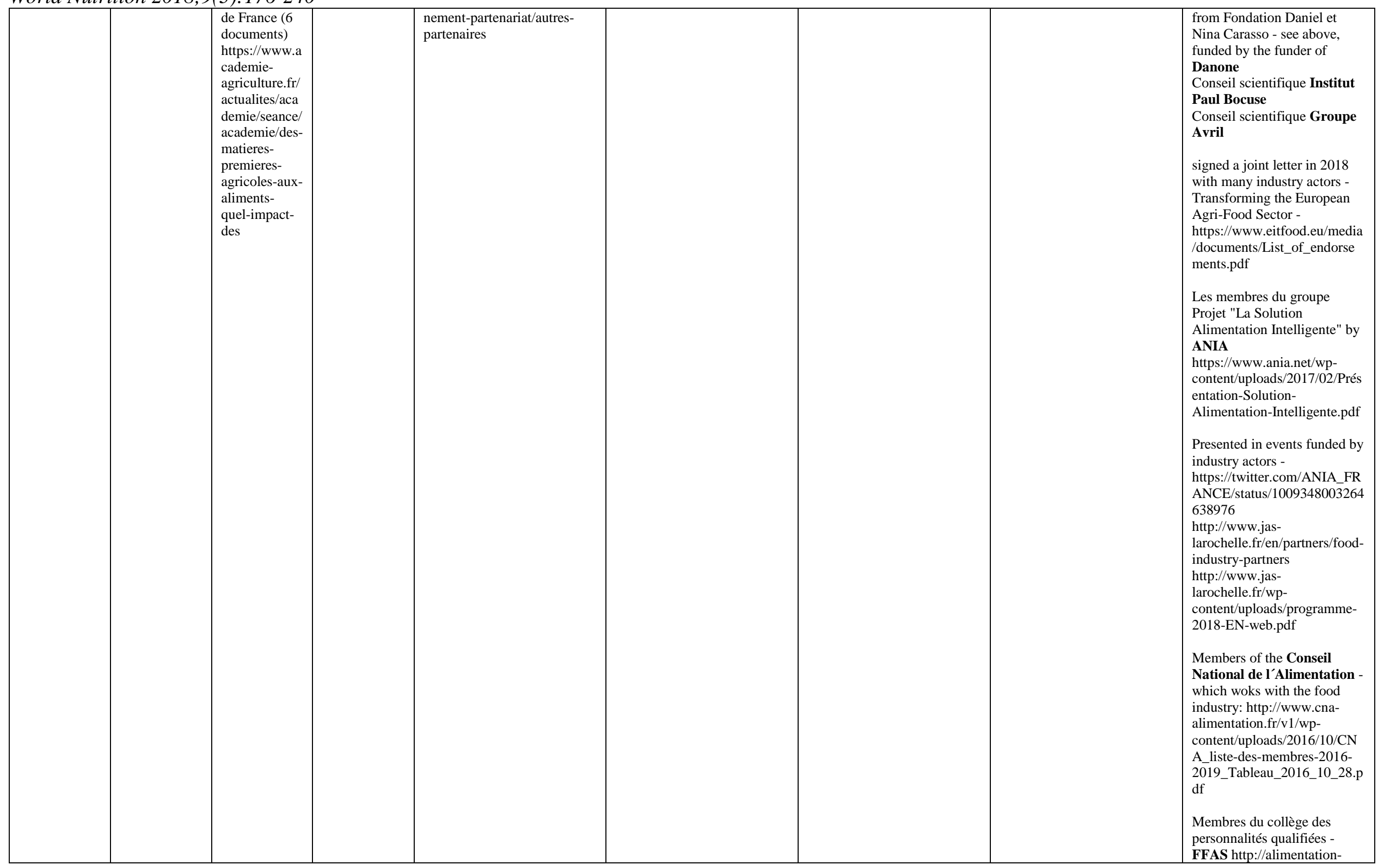


World Nutrition 2018;9(3):176-240

\begin{tabular}{|c|c|c|c|c|c|}
\hline & & & & & $\begin{array}{l}\text { sante.org/organisation/conseil } \\
\text {-dadministration/ }\end{array}$ \\
\hline Vialta Airton & ITAL, Brazil & $\begin{array}{l}\text { The Myth of } \\
\text { Ultra- } \\
\text { Processed } \\
\text { Foods. EC } \\
\text { Nutrition. } \\
+ \\
\text { Brasil } \\
\text { Processed } \\
\text { Food 2020 } \\
\text { a. publication: } \\
\text { ITAL. } \\
\text { Alimentos } \\
\text { industrualuza } \\
\text { dos: a } \\
\text { importancia } \\
\text { para a } \\
\text { sociedade } \\
\text { brasileira . } \\
\text { Editores: } \\
\text { Rego R. A., } \\
\text { Vialta A. and } \\
\text { Madi L. 2018. } \\
\text { http://aliment } \\
\text { osindustrializ } \\
\text { ados.com.br/2 } \\
\text { / } \\
\text { b. website: } \\
\text { http://www.al } \\
\text { imentosproce } \\
\text { ssados.com.br } \\
\text { /plataforma.p } \\
\text { hp }\end{array}$ & $\begin{array}{l}\text { EC Nutrition : Predatory } \\
\text { journal }\end{array}$ & $\begin{array}{l}\text { With technical and scientific } \\
\text { information, without value } \\
\text { judgments or conflicts of } \\
\text { interest, the knowledge in } \\
\text { greater detail about the } \\
\text { products and their ingredients } \\
\text { and forms of processing can } \\
\text { serve as support to the } \\
\text { purchasing decisions of the } \\
\text { Brazilian consumers, in the } \\
\text { exercise of their free will }\end{array}$ & $\begin{array}{l}\text { COMITÊ TÉCNICO- } \\
\text { CIENTÍFICO DO WEBSITE } \\
\text { "ALIMENTOS } \\
\text { PROCESSADOS" - together } \\
\text { with industry actors: ABIA, } \\
\text { International Academy of } \\
\text { Food Science and } \\
\text { Technology - IAFoST, IFIC, } \\
\text { Instituto mauá de } \\
\text { Tecnologia - IMT, } \\
\text { Sociedade Brasileira de } \\
\text { Ciência e Tecnologia de } \\
\text { Alimentos - SBCTA } \\
\text { http://www.alimentosprocess } \\
\text { ados.com.br/comite.php } \\
\text { ITAL lança portal de } \\
\text { conteúdo sobre alimentos } \\
\text { processados } \\
\text { Fazem parte deste grupo } \\
\text { profissionais de instituições } \\
\text { como a Associação Brasileira } \\
\text { de Editores Científicos } \\
\text { (Abec), Associação } \\
\text { Brasileira das Indústrias de } \\
\text { Alimentação (Abia), } \\
\text { Associação Brasileira de } \\
\text { Nutrologia (Abran), } \\
\text { Faculdade de Engenharia de } \\
\text { Alimentos e Agrícola da } \\
\text { Universidade Estadual de } \\
\text { Campinas (FEA/Unicamp), } \\
\text { Faculdade de Ciências } \\
\text { Farmacêuticas da } \\
\text { universidade de São Paulo } \\
\text { (USP) e International Life } \\
\text { Sciences Institute do Brasil } \\
\text { (ILSI BRASIL). } \\
\text { http://www.ital.sp.gov.br/noti } \\
\text { cias.php?not_id=785 } \\
\text { Gave a presentation with } \\
\text { ILSI Nor-Andino and ITAL } \\
\text { as his organisations: } \\
\text { http://ilsi.org/wp- } \\
\text { content/uploads/2018/03/ITA } \\
\text { L-Dr-Airton-Vialta- } \\
\text { 20octubre2016.pdf } \\
\text { http://ilsi.org/regional- }\end{array}$ \\
\hline
\end{tabular}


World Nutrition 2018;9(3):176-240

\begin{tabular}{|c|c|c|c|c|c|c|}
\hline & & & & & & $\begin{array}{l}\text { collaboration/ } \\
\text { http://elnoti.com/ilsi-nor- } \\
\text { andino-presenta-rol-la- } \\
\text { ciencia-la-tecnologia- } \\
\text { alimentos-bogota/ } \\
\text { http://ilsi.org/event/food- } \\
\text { science-and-technology/ }\end{array}$ \\
\hline $\begin{array}{l}\text { Weaver } \\
\text { Connie }\end{array}$ & $\begin{array}{l}\text { Purdue } \\
\text { University, } \\
\text { USA }\end{array}$ & $\begin{array}{l}\text { Processed } \\
\text { foods: } \\
\text { contributions } \\
\text { to nutrition. } \\
\text { American } \\
\text { Journal of } \\
\text { Clinical } \\
\text { Nutrition. }\end{array}$ & $\begin{array}{l}\text { American } \\
\text { Journal of } \\
\text { Clinical } \\
\text { Nutrition }\end{array}$ & $\begin{array}{l}\text { See Journal of the American } \\
\text { Society for Nutrition }\end{array}$ & $\begin{array}{l}\text { CM Weaver, serves as an } \\
\text { unpaid board member for the } \\
\text { International Life Sciences } \\
\text { Institute of North America } \\
\text { and serves on a scientific } \\
\text { advisory board for } \\
\text { Pharmavite and her } \\
\text { university has received } \\
\text { research grants from the } \\
\text { Dairy Research Institute, } \\
\text { Nestlé, and Tate \& Lyle }\end{array}$ & $\begin{array}{l}\text { https://www.healthpolicyjrnl. } \\
\text { com/article/S0168- } \\
\text { 8510(13)00022-5/pdf: } \\
\text { publishes for ILSI North } \\
\text { America } \\
\text { Vice Chair of the ILSI } \\
\text { Board of Trustees and } \\
\text { Chair of the ILSI Board } \\
\text { Publications Committee } \\
\text { http://ilsi.org/connie-weaver/ }\end{array}$ \\
\hline
\end{tabular}

